\begin{abstract}
Title of Document:

THE EFFECT OF LAND USE REGULATION ON HOUSING PRICE AND INFORMALITY: A MODEL APPLIED TO CURITIBA, BRAZIL

Maria Teresa Xavier Souza

Directed By:

Professor Gerrit J. Knaap

Urban Studies and Planning Program

Director, National Center for Smart Growth

Research and Education
\end{abstract}

Developing countries have been experiencing an accelerated urban growth with high levels of informal housing (houses that do not comply with property rights regime and urban regulations). This trend has brought renewed attention to the study of developing cities in general, and of the informal housing sector in particular. This study examines the relationship between land use regulation, housing price, and informality, in the metropolitan area of Curitiba, Brazil.

Using a simultaneous equation model, the study conducts a regression analysis to understand the magnitude of the effect of urban regulation on formal housing price and the effect of rising formal housing price on the quantity of informal housing. Three hypotheses are tested: (a) more restrictive land use regulation increases housing price in the formal housing market; (b) an increase in formal housing price causes the 
quantity of informal housing to rise; and (c) an increase in formal housing price in one geographic area causes the quantity of informal housing to rise in neighboring areas.

The study shows that for three regulatory variables - minimum plot area, minimum front setback and minimum frontage - land use regulations that limit the density of occupation have a significant positive effect on price. Regulatory variables that affect building height - maximum number of floors and floor-to-area ratio - have the opposite effect, possibly because single and multifamily units are not being analyzed separately.

The study finds that the price of formal housing has a negative effect on the quantity of informal housing in the same location, but this effect turns positive in the adjacent and more distant locations. As expected, the rise in formal housing price in one locality pushes people to the informal sector in more distant neighborhoods. However, in the same locality, a rise in price decreases the quantity of informal housing. The results indicate that high priced areas act as a bar to the development of the informal sector in the same locality (explaining the negative coefficients of formal housing price) while the informal sector is being pushed to the outskirts of the city (explaining why the lagged price variables become positive and have an increasing effect on the quantity of informal housing as the locations move further away from each other). 


\title{
THE EFFECT OF LAND USE REGULATION ON HOUSING PRICE AND INFORMALITY: A MODEL APPLIED TO CURITIBA, BRAZIL
}

\author{
By \\ Maria Teresa Xavier Souza \\ Dissertation submitted to the Faculty of the Graduate School of the \\ University of Maryland, College Park, in partial fulfillment \\ of the requirements for the degree of \\ Doctor of Philosophy \\ 2009
}

Advisory Committee:

Dr. Gerrit J. Knaap, Chair

Dr. Marie Howland

Dr. Alexander Chen

Dr. Maureen Cropper

Dr. Lori Lynch 
(C) Copyright by

Maria Teresa Xavier Souza

2009 


\section{Dedication}

I dedicate this dissertation to my husband, Raghav Kotval, an enthusiastic and unconditional supporter of my projects. 


\section{Acknowledgements}

I would like to thank my advisor Gerrit J. Knaap, who kept me focused, and the members of the committee, Marie Howland, Alexander Chen, Maureen Cropper, and Lori Lynch, for their suggestions and comments.

My heartfelt thanks to Katia Regina Schmeiske, who organized an effective team of competent women to help collect the data and became a good friend in the process; and to Luis Alceu Paganotto, an analyst at the Institute of Geography and Statistics (IBGE) in Curitiba who helped compile a seemingly endless list of census data.

I am in debt to the public servants and officials in Curitiba and the metropolitan area who were generous with their time and gave me access to their files which became the primary data for this dissertation. They include: Mr. Beto Richa, mayor of the municipality of Curitiba; Mr. Mauricio Ferrant, secretary of government of the municipality of Curitiba; Ms. Cristiana Camargo Gusso, international relations adviser of the municipality of Curitiba; Mr. Luiz Eduardo Sebastiani, secretary of finance of the municipality of Curitiba; Mr. Altevir Belo, director of the property tax division of the municipality of Curitiba and his staff; Mr. Wilhem Eduard Milward de Azevedo Meiners, technical director of Curitiba Metropolitan Area Company (COMEC); Mr. Raul Peccioli, chief of the department of territorial organization control of COMEC, and his staff; Ms. Bernardete Jede, executive coordinator of the Parana Institute of Research and Development of the Real Estate Market (INPESPAR); and the mayors, and secretaries of urban planning and finance, and 
their respectively staff of the municipalities of Almirante Tamandaré, Araucária, Campina Grande do Sul, Campo Largo, Colombo, Fazenda Rio Grande, Pinhais, Piraquara, Quatro Barras, and São José dos Pinhais.

I would like to acknowledge several colleagues who helped with different aspects of the dissertation: Nikhil Kaza, Carolina Burnier, and Jung Ho Shin from the urban studies and planning department; Juliana Dutra Araujo and Victor Macias from the economics department; and Timothy Fitzgerald, a former student from the agriculture and resource economics department.

I am grateful to the World Bank for authorizing access to the database from their study of the land market in the metropolitan area of Curitiba. My special thanks to Oscar Schmeiske, director of the Curitiba Institute of Urban Planning and Research (IPPUC)'s geographic information department, for facilitating access to its database. I am also thankful for the financial support provided by the Lincoln Institute of Land Policy and the University of Maryland.

Finally, on a personal note, I would like to thank my parents, Paulo Renato and Giovanna and my in-laws Indira and Jim, for their love and support.

Last, but not least, I would like to thank my husband Raghav, who encouraged me from the beginning to the end of this journey and was a dedicated reader and editor of papers and dissertation drafts. 


\section{Table of Contents}

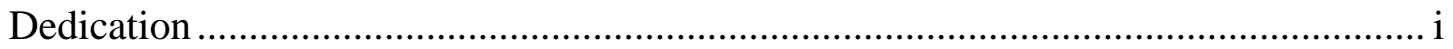

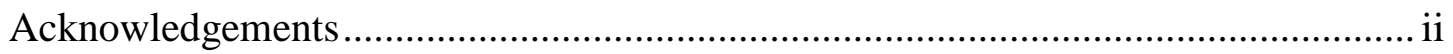

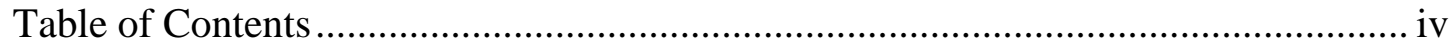

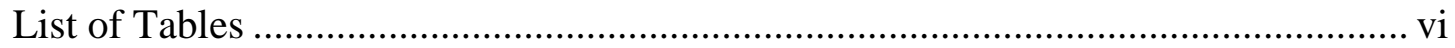

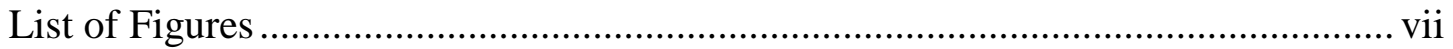

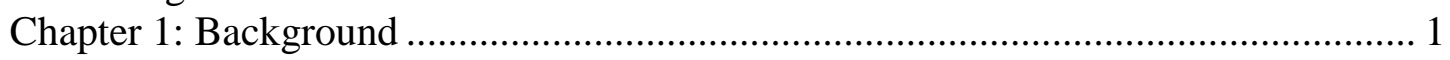

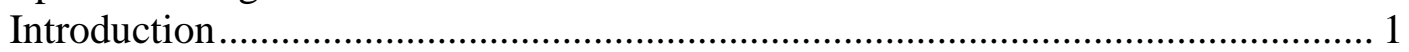

Historic Context for the Emergence of the Informal Housing Sector in Brazil........ 4

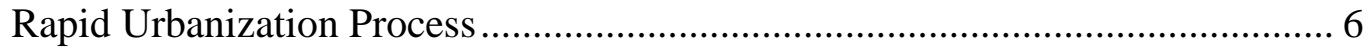

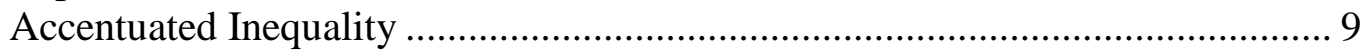

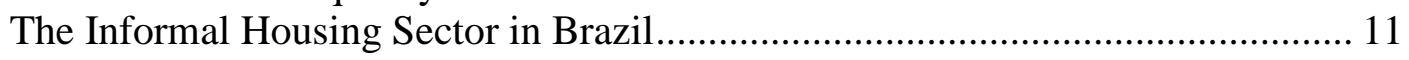

Housing and Urban Policies in Brazil................................................................. 19

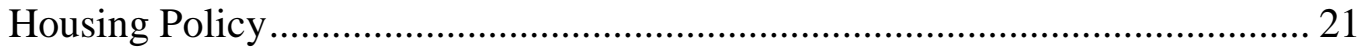

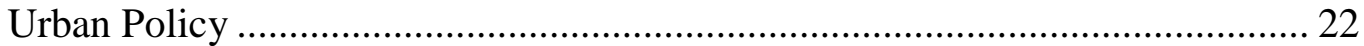

The Metropolitan Area of Curitiba ................................................................... 30

The Informal Housing Sector........................................................................ 34

Urban Planning in the Study Area .................................................................. 38

Municipal Legislation in the Study Area ....................................................... 38

State Legislation for the Metropolitan Area of Curitiba ................................ 45

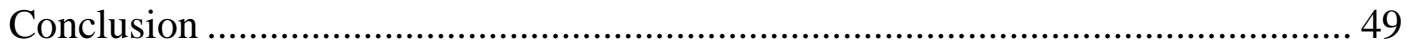

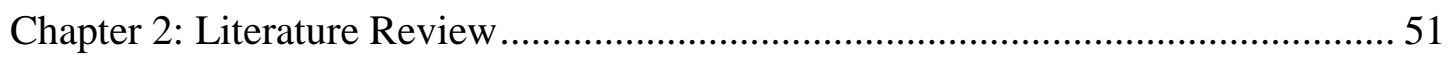

The Effect of Land Use Regulation on Housing Price .................................... 51

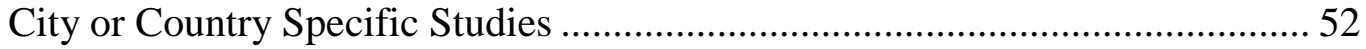

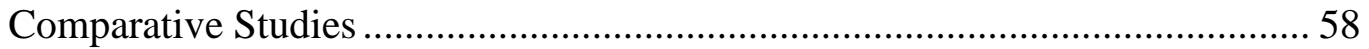

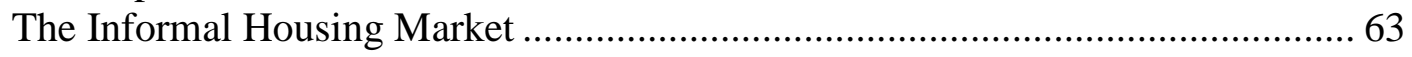

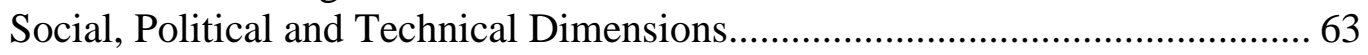

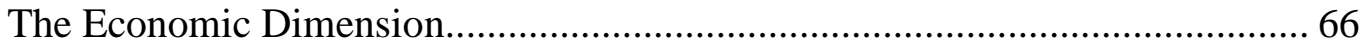

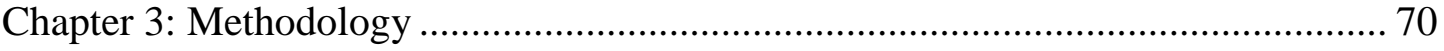

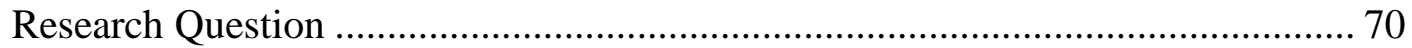

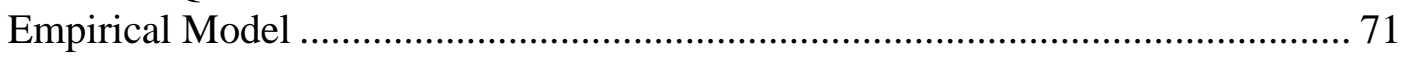

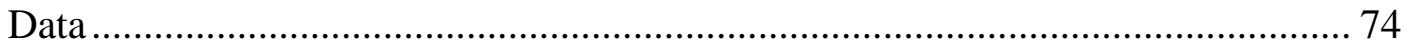

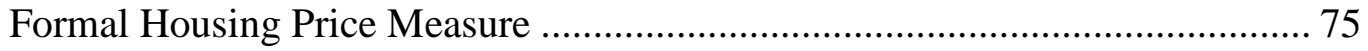

Urban Regulation Measure .................................................................... 76

Quantity of Informal Housing Measure .................................................... 78

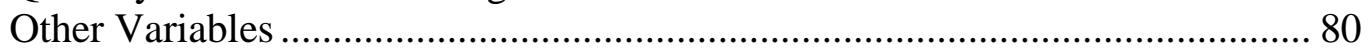

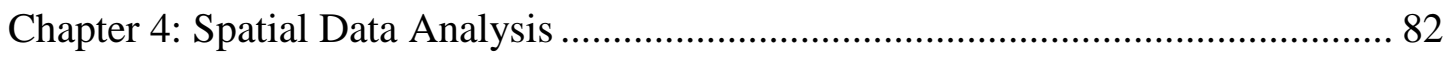

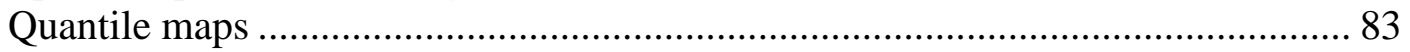

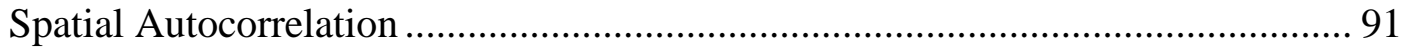

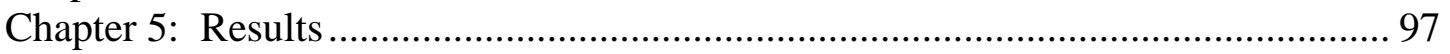

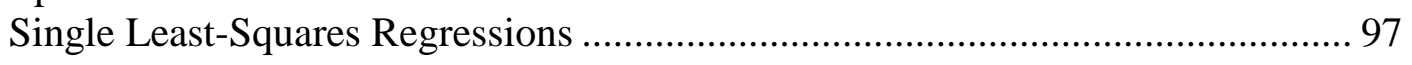

Formal Housing Price Model.................................................................. 97

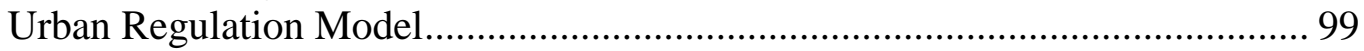

Quantity of Informal Housing Model .......................................................... 102 
Three-Stage Least-Squares Regression.......................................................... 104

Single Versus Three-Stage Least-Squares Regression .................................... 114

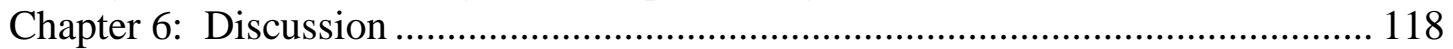

Overview of the Findings of the Study ........................................................ 119

The effect of land use regulation on formal housing price ............................ 119

The effect and spatial pattern of price determination on informality .............. 120

Implications for Urban Policy Practice in Brazil.............................................. 121

Limitations of the Study............................................................................. 122

Scale, Period and Sample Size............................................................... 122

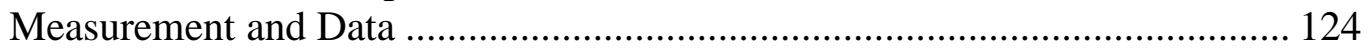

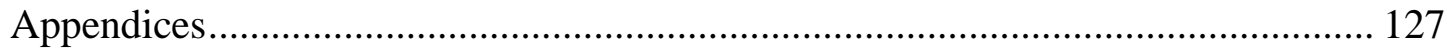

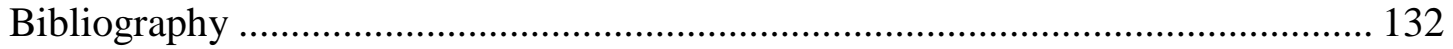




\section{List of Tables}

Table 1 - Share in the State of Parana's Added Fiscal Value 1975-2000

Table 2 - Annual Rate of Population Growth in the Metropolitan Area of Curitiba 1970-2000

Table 3 - Summary of Main Zoning Laws in the Study Area ................................. 45

Table 4 - Summary of Regulatory Measures and Methods ..................................... 52

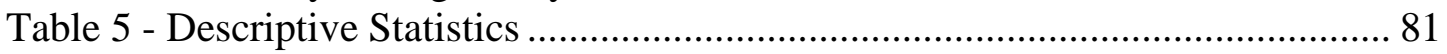

Table 6 - Moran's I Test for Formal Housing Price Variable ................................... 95

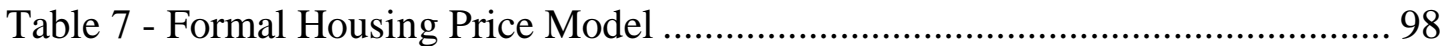

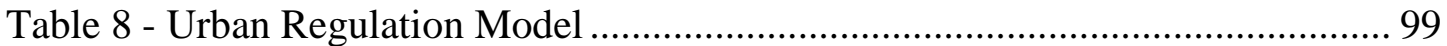

Table 9 - Expected Signs of Urban Regulation Variables Versus Density................ 100

Table 10 - Quantity of Informal Housing Model .................................................... 103

Table 11 - Three-Stage Least-Squares Regression Model...................................... 106

Table 12 - Summary of the Effect of Formal Housing Price on the Quantity of

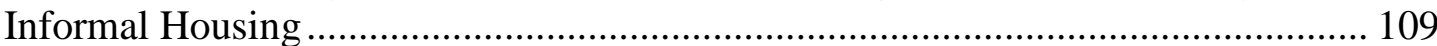

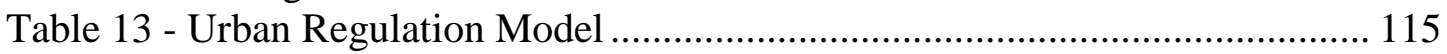

Table 14 - Formal Housing Price Model ................................................................ 116

Table 15 - Quantity of Informal Housing Model .................................................... 117 


\section{List of Figures}

Figure 1 - Brazil Demographic Density .............................................................. 5

Figure 2 - Favela Rocinha, Rio de Janeiro............................................................... 13

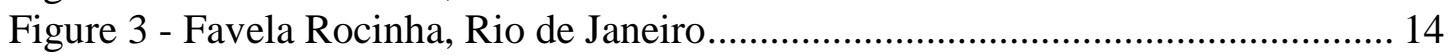

Figure 4 - Loteamento Irregular Parque Esperanca, Sao Paulo ................................. 17

Figure 5 - Loteamento Irregular Parque Esperanca, Sao Paulo ................................. 17

Figure 6 - The Metropolitan Area of Curitiba ........................................................ 31

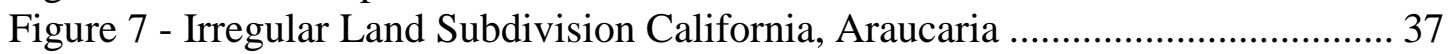

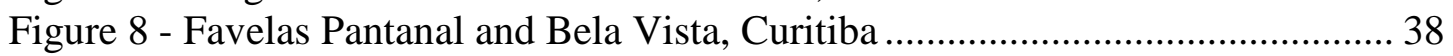

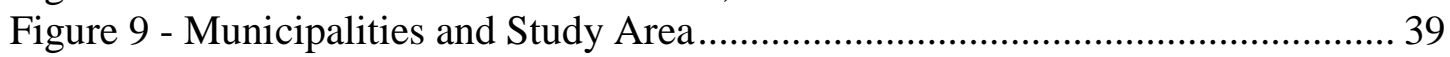

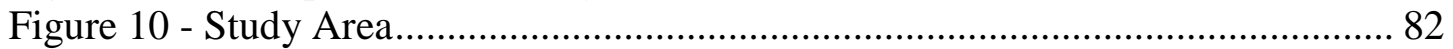

Figure 11 - Quantile Map with Median Formal Housing Price R\$ (2000)................ 83

Figure 12 - Quantile Map with Median Household Monthly Income R\$ (2000)....... 84

Figure 13 - Quantile Map with Percentage of Informal Housing (2000) .................. 85

Figure 14 - Quantile Map with Percentage of Houses w/ Water Connection (2000) . 86

Figure 15 - Quantile Map with Percentage of Houses w/ Sewage Connection (2000)

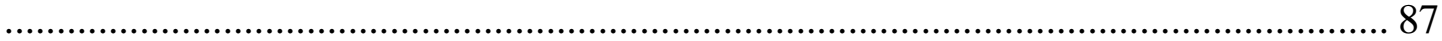

Figure 16 - Quantile Map of Median Zoning Regulation - Minimum Plot Area ....... 88

Figure 17 - Quantile Map of Median Zoning Regulation - Maximum Number of

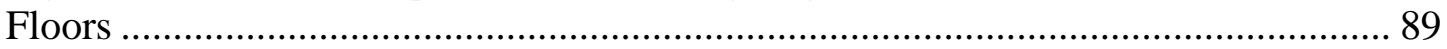

Figure 18 - Quantile Map of Median Zoning Regulation - Minimum Front Setback 89

Figure 19 - Quantile Map of Median Zoning Regulation - Minimum Frontage ........ 90

Figure 20 - Quantile Map of Median Zoning Regulation - Occupation Ratio............ 90

Figure 21 - Quantile Map of Median Zoning Regulation - Floor-to-Area Ratio........ 91

Figure 22 - Map of Study Area with Original Polygon Shape ................................ 92

Figure 23 - Map of Study Area with Thiessen Polygon Shape................................. 92

Figure 24 - Map of Study Area with Point Shape (Centroids) .................................. 93

Figure 25 - LISA Cluster Map of Formal Housing Price Variable............................. 96

Figure 26 - LISA Cluster Map of Formal Housing Price Variable........................... 112

Figure 27 - LISA Cluster Map of Quantity of Informal Housing Variable .............. 113 


\section{Chapter 1: Background}

\section{$\underline{\text { Introduction }}$}

Most urban growth over the past 50 years has taken place in developing countries. Between 1950 and 1995 the number of cities in developed countries doubled, while it increased six fold in developing countries (Linden 1996). A continuation of this trend is anticipated. A recent World Bank study expects the urban population in industrialized countries to grow by $11 \%$, from approximately 0.9 billion in 2000 to 1 billion in 2030. In contrast, developing countries' cities are expected to double in the next thirty years, from approximately 2 billion in 2000 to approximately 4 billion in 2030 (Angel, Sheppard and Civco 2005).

A major feature distinguishing urban growth in developed countries from most developing countries is the role played by informal housing (houses that do not comply with property rights regime and urban regulations). While in industrialized countries housing is largely delivered in compliance with property rights regimes and urban regulations (such as land use regulations, building codes, and subdivision standards), in most developing countries, low and moderate income households, which can constitute $50 \%$ of the urban population, are housed by the informal sector (Dowall 1992). 
The combination of these trends in developing countries - accelerated urban growth and its association with high levels of informality - has brought renewed attention to the study of developing cities in general, and of urban informality in particular (e.g. Roy and Alsayyad 2004, Drakakis-Smith 2000, Pamuk 2000, and Barross and Linden 1990). The central problem many authors face is that most urban theories and empirical models are rooted in the developed world and do not take into consideration the specificities of urban development in developing countries, such as the role of the informal sector (Roy 2005).

The literature attempting to model the relationship between land use regulation and housing price is a case in point. While several studies analyze the effects of land use regulation on housing price, most studies focusing on developing countries do not control for differences between the effect of land use regulation on formal and informal housing and the relationship between these housing markets.

The purpose of this study is to address these issues. The study will develop a model to estimate the effect of urban regulation on formal housing price and the effect of changes in housing price on the quantity of informal housing. The model will be applied to thirteen municipalities that are part of the metropolitan area of Curitiba, Brazil, with a population of approximately 2.6 million (2000).

Although Curitiba is internationally renowned for its success (the city was voted the most innovative city in the world in the Habitat II Conference in Istanbul, 1996) and 
innovation in the implementation of urban planning policies, the city faced major challenges with a rapid increase in population, brought about by a significant investment from multinational corporations. Since the early 1990s, industries have been moving out of Sao Paulo, and Curitiba has been a prime destination because of its quality of life. The area has attracted corporate entities such as Renault (US\$1 billion), Audi/Volkswagen (US\$800 million), and BMW/Chrysler (US\$500 million) (Nojima et al. 2004). The metropolitan area experienced an annual population growth of $3.12 \%$ between 1991 and 2000. As not all households that move to the city can afford a house in the formal market, there has been an expansion of informal land developments.

Viewed in this context, Curitiba provides an excellent opportunity to understand whether land use regulation is playing a significant role in increasing formal housing price and pushing people to the informal housing market. First, because Curitiba has a growing population, a necessary condition to observe rising housing prices and assess whether regulation has an effect on it. Second, Curitiba has an established tradition in the use of land use regulation, unlike any other city in Brazil. Third, the informal housing sector is increasing, attracted by the economic growth. Finally, Curitiba and the metropolitan area have been renowned for having among the best institutional capacities in government and research agencies in the country, facilitating data collection. 


\section{Historic Context for the Emergence of the Informal Housing Sector in Brazil}

Before analyzing the informal housing sector in the metropolitan area of Curitiba it is important to understand the causes for the emergence of the informal housing sector in Brazil, its characteristics and the public policies toward it. Despite the great level of autonomy experienced by municipalities over the past 20 years, the Federal government centralized several aspects of housing and urban development policies before, influencing greatly the policies towards the informal sector in all the country. This section will also explain some of the differences between the urbanization process of Curitiba, Parana, and the rest of the country. Finally, it will explain how the recent economic growth is closely associated with the decentralization of the industry from the state of Sao Paulo, which has brought a delayed growth in population and in the informal housing sector in the metropolitan area of Curitiba in comparison with other parts of the country.

Brazil expands across 8.5 million square kilometers, occupying $47 \%$ of South America. It has 26 states and 5,563 municipalities (2003). It is only slightly smaller than the United States, which has 9.2 million square kilometers of land area. Brazil is the fifth most populous country in the world and is highly urbanized. It has a population of 180 million people of which $81 \%$ live in urban areas (2004) ${ }^{1}$. Figure 1 shows a map of Brazil with the states' boundaries and demographic density in 2000 .

\footnotetext{
${ }^{1}$ The Brazilian Institute of Geography and Statistics (IBGE), which acts as the census bureau in Brazil, defines as urban all areas that are contained inside the municipalities' urban perimeter. Municipalities are required by the Federal Tax Code of 1967 to define by law an urban perimeter in order to apply an
} 


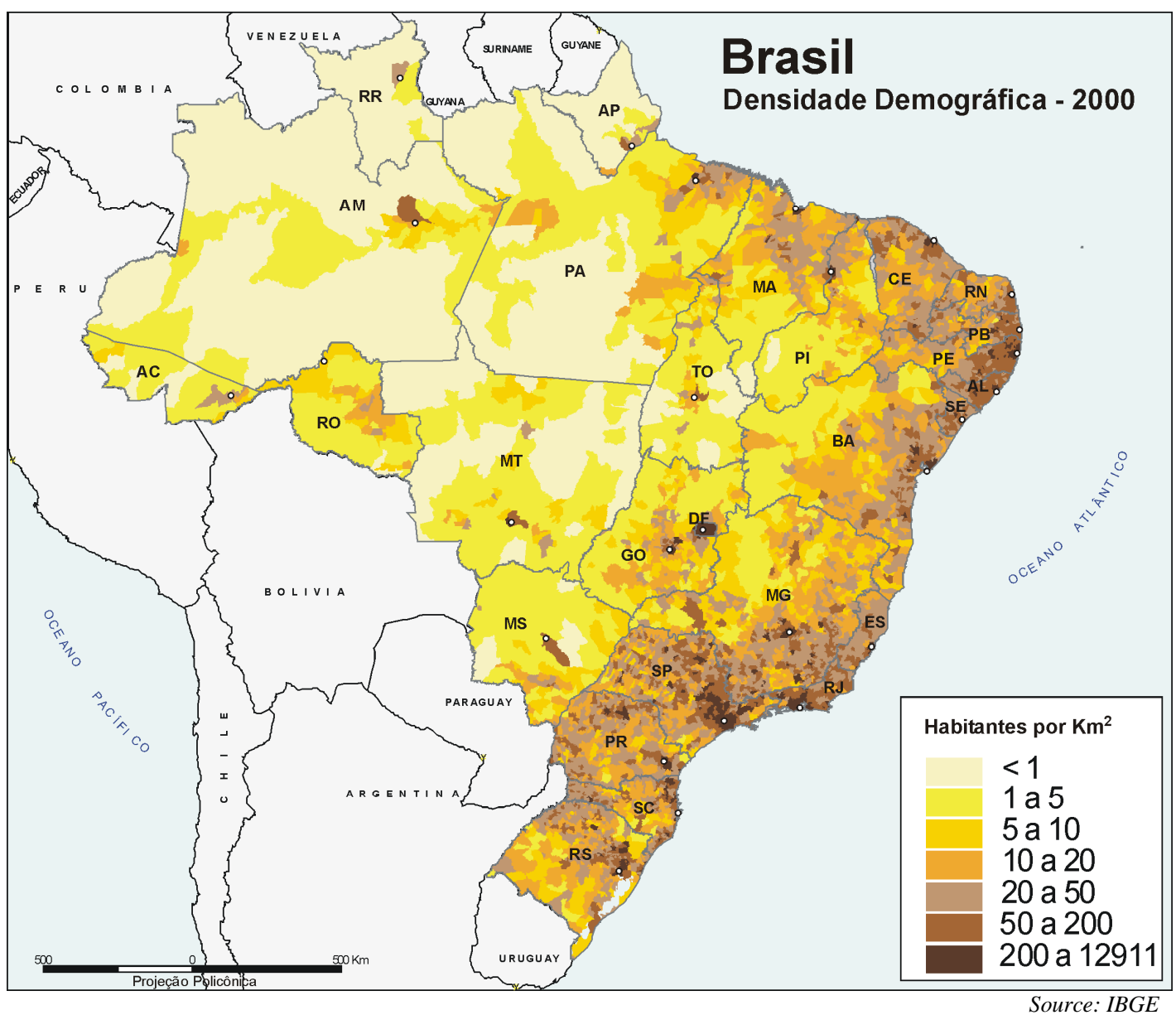

Figure 1 - Brazil Demographic Density

The southeast region - comprised of the states of Sao Paulo (SP), Rio de Janeiro (RJ), Minas Gerais (MG) and Espirito Santo (ES) - is the most densely populated area in the country and the one with the highest participation in the national economy. It houses $43 \%$ of the total population and it produces $64 \%$ of the national Gross Domestic Product (GDP) (2000). Parana (PR), the state of which Curitiba is the capital and economic center, is located in the south region and it borders Sao Paulo to

urban property tax (a municipal tax) inside this perimeter and a rural property tax (a federal tax) outside this perimeter. 
its north. Parana has the $5^{\text {th }}$ largest economy in the country in terms of its contribution to the national GDP and ranks $6^{\text {th }}$ among states in terms of its population.

The growth of the informal housing sector in Brazil is closely associated with two factors: a rapid urbanization process between 1940 and 1980 and an extremely unequal distribution of income.

\section{Rapid Urbanization Process}

The share of urban population in Brazil increased from $36 \%$ to $80 \%$ between 1950 and 2000 (United Nations 2004). The rapid urban growth was a result of a massive migration from rural to urban areas. Factors contributing to the rural exodus and urban explosion of the period were the rapid industrialization process that started in the 1930s and increased significantly between 1950 and 1980 as a result of a deliberate policy of industrial development promoted by the state. Over the course of the key 30 year period, the average rate of industrial production reached approximately 9\% a year (Suzigan 1984 and 1988, Cano 1989, Dedecca 2005).

Another critical factor contributing to rural flight was the maintenance of the concentration of land ownership in rural areas. The combination of rapid modernization while entire swaths of the country maintained its traditional agrarian structure inherited from colonial times created an urbanization that was "precocious and disorganized" as described by Cano (1989). 
Until 1950, Brazil inherited from the colonial period a fragmented system of cities that were predominantly located along the coast, where agricultural and extraction products were exported to Europe, and imported products where channeled inland. These cities had more ties to European cities than to each other, because of the limited transportation system connecting them (Taschner 2003). With the industrialization process, the state invested heavily in a road system to connect cities and integrate regional markets. This national road system facilitated the domestic distribution of goods from industries concentrated in the southeast to the rest of the country, and supported the flow of labor coming from the northeast and the rural areas to the southeast.

This period was also marked by population growth in the metropolitan $\operatorname{areas}^{2}$. The share of the population in metropolitan areas grew from $21.5 \%$ in 1960 to $29 \%$ in 1980. Between 1970 and $1980,41 \%$ of the national population growth took place in metropolitan areas (Taschner 2003).

\footnotetext{
${ }^{2}$ In Brazil, metropolitan areas were defined by the Constitution of 1967, which gave the Union the mandate to create them by legislation. The Constitution defined metropolitan areas as a group of municipalities that were part of the same socioeconomic unit and that could use common services. In 1973 and 1974, two federal laws created the first nine metropolitan areas of the country, including Sao Paulo and Curitiba. The federal law also required the states to create councils for the institutionalization of the metropolitan areas. The Constitution of 1988 decentralized to the states, the power to create metropolitan areas and to define its institutional framework. There are now 29 metropolitan areas in 18 states in Brazil (COMEC 2006).
} 
Because of the continental size of the country and historic conditions, Brazil's urbanization process created important regional differences. Most parts of the north region were left unexplored, with the exception of Manaus and other capital cities. The Northeast, maintained a traditional rural property system inherited from the colonial times and had a disperse urbanization process centered in the nine capital cities. The central-west region had an urbanization process that was polarized by the construction of Brasilia, which was inaugurated in 1960 and by the end of the 1980s was already the $7^{\text {th }}$ largest city in Brazil. The southeast, especially the state of Sao Paulo, was the region that experienced the most rapid urbanization process between 1950 and 1980, due to regional migration seeking employment in the county's dominant industrial and service centers (Cano 1989).

The urbanization process of the south has been historically more balanced than the rest of the country, because the industrialization process was more gradual and its agricultural sector was based on a more equitable distribution of property and income (Cano 1989). Parana was one such example, although its urbanization process accelerated rapidly in the 1980s due to the modernization of the agricultural sector and the expansion of the industrialization process from the metropolitan area of Sao Paulo to the metropolitan area of Curitiba.

Over the past 20 years, there have been some changes in the growth and distribution of cities in Brazil. Medium size cities have been growing more rapidly and the growth of metropolitan areas has decreased significantly. Between 1996 and 2000, the 
population of medium size cities $(100,000$ to 200,000 inhabitants) grew at $2.74 \%$ a year while large cities with more than 1 million inhabitants grew at $1.87 \%$ a year (Taschner 2003). Another important change between 1980 and 2000 was the multiplication of municipalities due to fiscal incentives provided by the new constitution of 1988. The total number of municipalities in the country changed from 3,991 in 1980 to 5,507 in 2000. Parana experienced a similar trend. The total number of municipalities grew by $25 \%$ from 318 to 399 municipalities between 1988 and 2000.

Accentuated Inequality

An important characteristic of the economic growth that took place in the second half of the $20^{\text {th }}$ century was the accentuated inequality of income distribution, which had a spatial impact in Brazilian cities. Measured by the Gini coefficient for the distribution of household income per capita, inequality in Brazil rose from 0.500 in 1960 to 0.565 in 1970 reaching 0.625 in 1989, when Brazil's inequality was the second highest in the world, narrowly following Sierra Leone's Gini coefficient of 0.629 (Ferreira et al 2006). Other measures of income distribution similarly show a high degree of inequality in Brazil. For example, the ratio of the share of the population in the top $20 \%$ of the income distribution to the bottom $20 \%$ equal to 32.1 in 1989 , compared with an average of 5.5 in South Asia during the 1960s-1990s and 6.3 in the industrial and high income developing countries during that time period (Clements 1997). 
Historically, authors have pointed to two structural factors that contributed to the unequal distribution of income in Brazil. First, the industrial growth that took place in the second half of the last century had an unequal salary structure. One study found that between 1966 and 1972, the salaries of executives had a real growth of $+7.2 \%$ a year, while the salary of qualified and non qualified workers had a real growth of + $3.1 \%$ and $-1.3 \%$, respectively (Sadoulet 1985 ). The minimum salary, which in Brazil has been an important factor in determining the base salary of most industries, lost $40 \%$ of its real value in the period between 1952 and 1974 (Souza and Tavares, 1981). This is significant when considering that in some large industries in Sao Paulo, such as the auto industry, $25 \%$ of workers received between 1 and 1.5 minimum salaries.

A second factor that contributed to the significantly unequal distribution of income in Brazil was the fact that the industrial sector didn't absorb all workers who emigrated from rural areas, leaving a large proportion of the workers dependent on the informal labor market, where in addition to low earnings there was greater vulnerability during periods of economic slowdown, such as between 1963 and 1967 and during the recession of the late 70 s and early 1980s.

In addition to structural factors that made Brazil one of the most unequal countries in the world, the periods of macroeconomic instability contributed to the deterioration of the purchasing power of low income families. This was especially true in the 1980s, 
when a period of hyperinflation increased inequality and poverty levels in Brazil to their highest levels (Ferreira et al 2006).

Since the early 1990s, there has been a change in the historical tendency in the distribution of income in Brazil. The Gini coefficient fell from 0.63 in 1989 to 0.56 in 2004 and poverty incidence fell from 0.33 in 1993 to 0.22 in 2004 . There are several factors that have contributed to this tendency, but the major ones have been the macroeconomic stability since the implementation of the economic reforms of 1994 and the increase in social assistance transfers targeted to the poor that started in the same period. Although there have been improvements, Brazil continues to be a very unequal country, having moved only from 2nd to 10th place in the world's ranking of income inequality (Ferreira et al 2006).

\section{The Informal Housing Sector in Brazil}

This section will discuss the two major forms of informal housing in Brazil referred to as favelas and loteamentos. The combination of the rapid urbanization process and the unequal distribution of income created a marginalized urban population that was unable to afford a formal housing solution. Formal rental units were scarce since the approval of the Renters Law of 1942, which discouraged investments in rental units by freezing rents well below inflation for two decades (Holston 1991). As a result, of the limited supply of affordable formal housing, low-income households were forced to find a housing solution in the informal housing market. In Brazil, a combination of two primary forms of informal housing solutions were used by the urban poor: 
squatter settlements (called "favelas" in Brazil) and irregular or clandestine land subdivisions (called "loteamentos").

Favelas originated with the invasion of public or private land by individual families or by an organized group of families generally in central location of metropolitan areas. In 1991, 78\% of the population living in favelas were concentrated in 9 metropolitan areas (Taschner 2003). The majority of favelas are located in the southeast region of Brazil, especially in the metropolitan area of Sao Paulo. In 1991, the southeast region housed $57 \%$ of the population in favelas. The south region had one of the smallest percentages, housing only $6 \%$ of the population in favelas.

The historic development, characteristics and prevalence of favelas as a housing solution for the urban poor varies across metropolitan areas in Brazil. Rio de Janeiro was one of the cities where favelas first started to expand in the beginning of the $20^{\text {th }}$ century. By 1950, favelas already housed $6.7 \%$ of the total population of Rio de Janeiro. This percentage grew to $13 \%$ in 1970 . In $1991,22 \%$ of the city's population lived in 604 favelas (Valladares and Figueiredo 1983, Prefeitura do Rio de Janeiro and Inter American Development Bank 2003).

Figure 2 and Figure 3 show favela da Rocinha, in Rio de Janeiro, the largest favela in Brazil with an estimated population of 200,000 inhabitants. The pictures show how the density of occupation and topographic characteristics, both common in these type of settlements in the city of Rio, are a barrier to the provision of infrastructure and 
services. As a consequence, regularization and infrastructure programs are unable to fully integrate favelas to the rest of the formal city, which is not the case of most irregular land subdivisions (loteamentos).

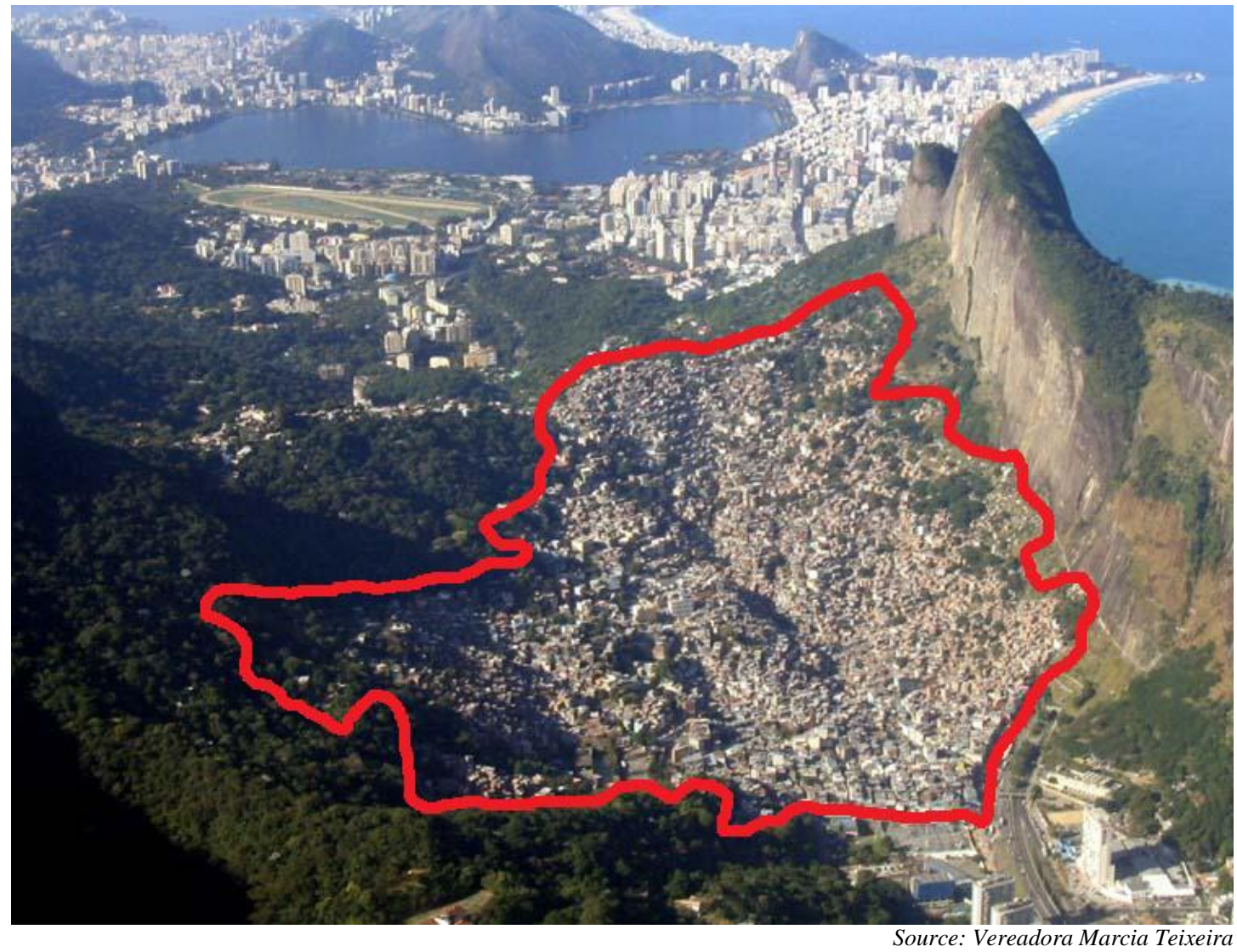

Figure 2 - Favela Rocinha, Rio de Janeiro 


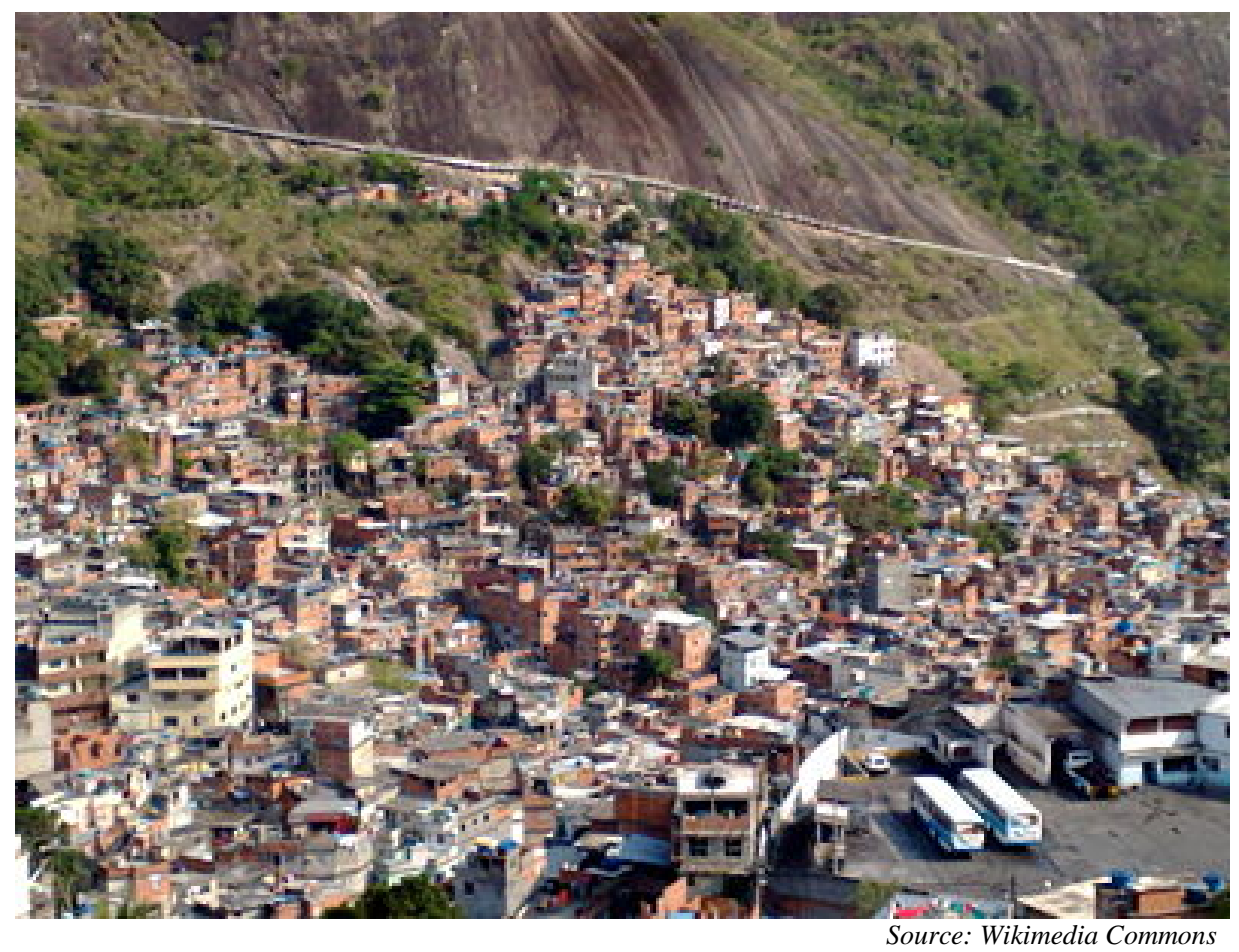

Figure 3 - Favela Rocinha, Rio de Janeiro

In Sao Paulo, favelas developed later and housed a smaller percentage of the population compared to other forms of informal housing. Until the 1970s, less than $1 \%$ of the population in the city of Sao Paulo lived in favelas. Between 1973 and 1993, this percentage grew to $19.8 \%$ or 1.9 million people (Taschner 2003). Although favelas grew rapidly in the 70 s and $80 \mathrm{~s}$, the prevalent housing solution for lowincome families in Sao Paulo was irregular or clandestine land subdivisions in the periphery of the city. In 1975, Kowarick (1980) estimated that 117,000 people lived in favelas in Sao Paulo, contrasted with 615,000 living in cortiços (informal rental rooms located in centrally located and deteriorated tenements) and 1.8 million living in irregular land subdivisions in the periphery of the city. By 1993, the population in favelas surpassed the population in cortiços, but irregular or clandestine subdivisions in the periphery of the city continued to be the predominant housing solution for the 
urban poor. The municipality of Sao Paulo estimated in 2000 that half of the population of the city or 5.5 million people lived in informal housing, 3 million in irregular or clandestine subdivisions, 1.9 million in favelas and 600,000 in cortiços (Folha de Sao Paulo 2000).

It is important to note that there is a very large variation in the number of favelas, depending on the source of information and the criteria adopted. For example, a comprehensive study contracted for by the municipality of Sao Paulo in 1993 estimated the number of people living in favelas at 1.9 million, while the census information for 1996 estimated only 748,000 people. Most of the difference is attributed to the census definition of favelas as a group of 51 housing units or more, while in the city of Sao Paulo $22 \%$ of favelas had less than 51 houses, according to the 1993 study. The sub estimation of this form of housing doesn't affect all cities in the same way. In Rio de Janeiro, the census estimates are closer to reality because favelas in the city are much larger and there is a smaller percentage of favelas with less than 51 housing units (Taschner 2003).

Irregular or clandestine land subdivision (loteamentos) ${ }^{3}$ was the main form in which the periphery of several Brazilian metropolitan areas expanded to absorb the large

${ }^{3}$ Fernandes (1997) defines irregular land subdivision as those promoted in precarious technical conditions, where their illegality is due to one or more of the following factors: the division is not registered in the public registry office, as developers lack the legal titles of property due to reasons ranging from land invasion to the registry offices' bureaucratic disorganization; the subdivision is located in a rural area; the project does not obey the existing legal requirements; developers fail to 
flow of migrants or families that were displaced by urban renewal and favela removal programs. The process involved the subdivision of land in individual plots by a developer who may or may not be associated with the land owner. Generally, these subdivisions were located on the fringes of the city, in many cases in rural areas where urban development was not permitted. Nothing more than dirt roads were generally provided and most of these subdivisions lacked infrastructure such as access to water, sewage, pavements and electricity. Low-income families paid for the plot over a period of five to ten years and built their houses on their own over time, starting with an improvised shack and improving it with more permanent materials in 10 or 20 years.

provide the urban infrastructure. Clandestine subdivisions are those developed in areas of contested ownership. 


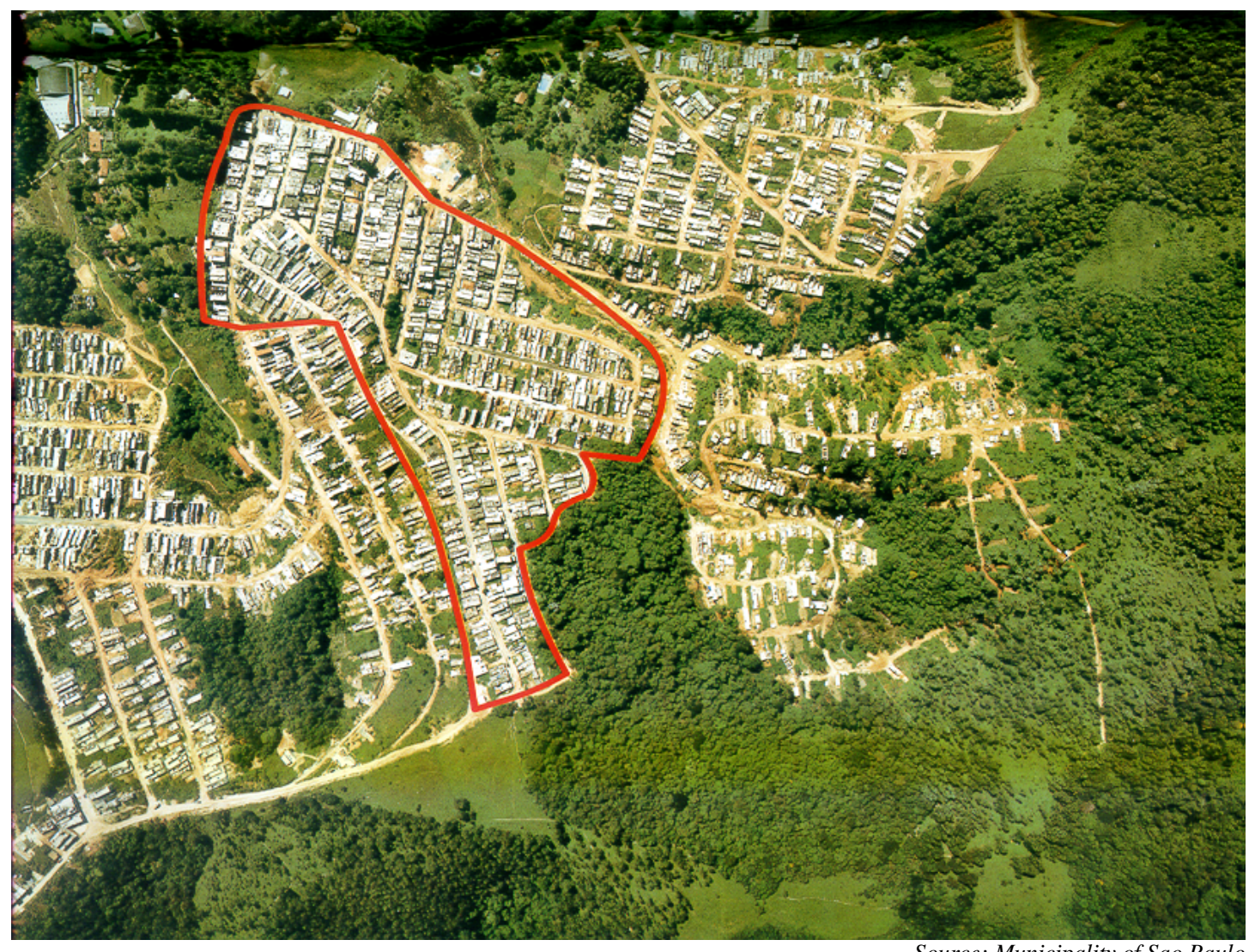

Figure 4 - Loteamento Irregular Parque Esperanca, Sao Paulo

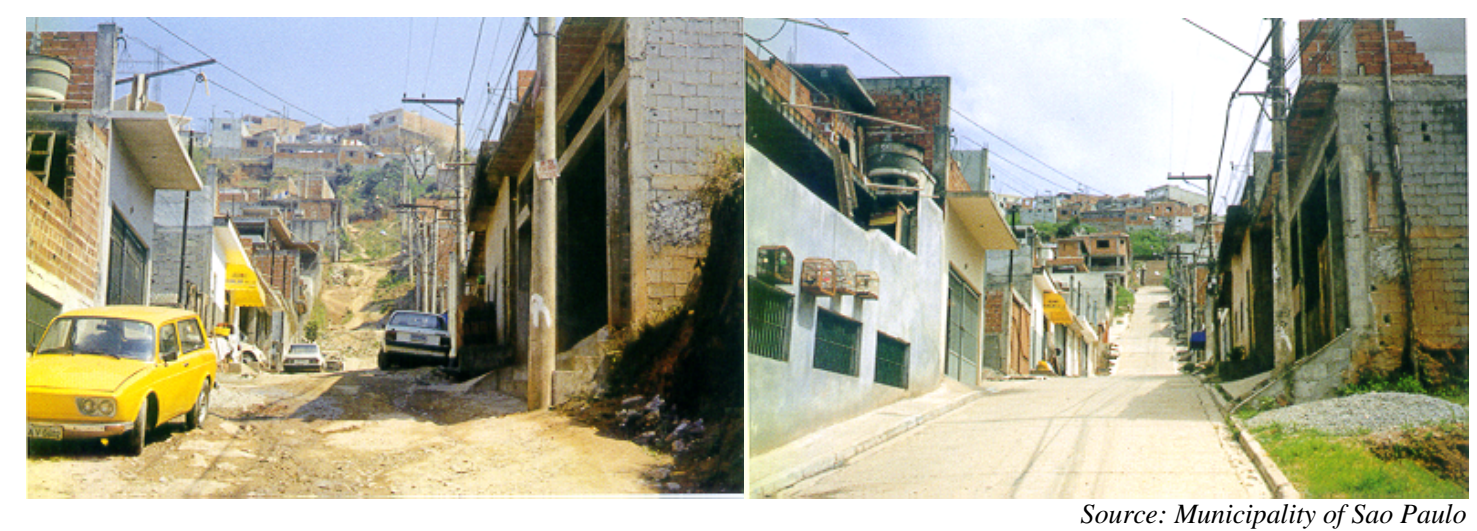

Figure 5 - Loteamento Irregular Parque Esperanca, Sao Paulo Before and After Regularization Program,

Figure 4 and Figure 5 show an irregular land subdivision (loteamento) in the city of Sao Paulo. Like several loteamentos, this one is located in the outskirts of the city, close to the mountain range to the north of the city. It has a planned street layout, and 
after improvements resulting from a municipal program to regularize and introduce infrastructure, it becomes more difficult to differentiate it from a formal development.

The expansion of the irregular or clandestine land subdivision began to occur in 1930 and intensified after 1950 (Valladares and Figueiredo 1983). In the west of the city of Rio de Janeiro, there was an increase in the number of irregular lots produced from 6,800 in the 1940 s, to 36,600 in the 1950 s. The production was reduced to 17,400 in the 1960s and 11,700 in the 1970s and almost vanished in the period of rapid inflation and recession of the 1980s, when favelas expanded significantly (Lago and Ribeiro 1996). In 1991, the city of Rio de Janeiro had 774 illegal subdivisions of which $65 \%$ were clandestine and $35 \%$ were irregular. The majority of the subdivisions (61\%) were located in the west of the city, where there is a higher concentration of lowincome people (Lago and Ribeiro 1996).

The exclusionary modernization of the Brazilian economy and the inequality of Brazilian society had an impact on the spatial configuration of the country's urban and metropolitan structure, marked by the spatial segregation of the poor (Maricato 1996). The rich lived in more central locations, where most public investments in services and infrastructure were concentrated, and where urban regulation and the law was more strictly enforced, limiting access to poor families. The poor, on the other hand, lived in the peripheries or in squatter settlements, without access to infrastructure and basic services, in precarious housing structures, and with insecure or inexistent rights over their property. In Sao Paulo, 67\% of head of households 
earning more than 20 minimum salaries were concentrated in the southwest portion of the central area, while the periphery accounted for $41 \%$ of head of households earning up to 1 minimum salary (Taschner 2003).

There have been some recent changes in these trends. First, there has been an important improvement in terms of urban and housing conditions in low income neighborhoods. For instance, in 1973 only 1.3\% of houses in the city of Sao Paulo's favelas had permanent structures, and in 1980, 65.4\% had access to electricity and $33 \%$ had access to water. In 1993, $75 \%$ of houses in the city of Sao Paulo's favelas had permanent structures, $90 \%$ had access to electricity and $60 \%$ had access to water (Taschner 2003).

A second change, starting in the 1980s, is the development of some high income gated communities in the peripheries of the cities following the American model of the suburbs. Several authors argue that the historic duality between center and periphery is not clear anymore in cities such as Sao Paulo. According to recent research, spatial segregation is happening more within neighborhoods; between high income developments that are isolated by gates and security technology, and low income developments (Taschner 2003).

\section{$\underline{\text { Housing and Urban Policies in Brazil }}$}

This section presents the changes in housing and urban policies that affected local policies toward the informal housing sector. It shows how the centralization of 
housing and urban policies in the period from the 1960s to the 1980s influenced state and municipal governments to focus their attention on the construction of public housing, and on the use of planning instruments to prevent the growth of informal settlements. During this period, municipalities didn't have much power to recognize the existence of the informal housing sector and target programs to this sector. This section also discusses the changes that were brought about by the Constitution of 1988, when urban regulation was encouraged to be more flexible or permissive to accommodate the reality of the informal sector. Additionally, municipalities gained autonomy and resources to define their own urban policies. Urban conditions in informal settlements were greatly improved as a consequence of these changes.

By the 1960s several sectors of Brazilian society were worried that the cities were growing in a disorderly pattern because of the flow of migrants to cities, the extraordinary expansion of urban areas, and the rapid growth of informal settlements. Several academics challenged this idea, arguing that there was logic to the disorderly way in which cities were being developed. However, when the military regime took power in 1964, the debate about the causes of the exclusionary urban development model of Brazilian cities was interrupted. Instead, the military regime addressed the issue on two fronts: (a) with the implementation of a radical restructure of the housing sector to expand the supply of new affordable formal housing; and (b) with the passage of new legislation and incentives at the federal level to prevent the growth of informal settlements. 


\section{Housing Policy}

A critical component in the reform of the housing sector included the creation of a Housing Finance System that in theory was unsubsidized, market operated and financially sustainable. The system was based on a monetary unit for underwriting mortgages that was indexed against inflation and financed by funds from a compulsory savings plan for formal workers of $8 \%$ of their salaries.

The National Housing Bank was created to centralize housing and sanitation policy and, originally, was intended to provide mortgages for three segments of the market: (a) the low-income segment for families earning 1 to 3 minimum salaries; (b) the median-to-low-income segment for families earning 3 to 5 minimum salaries; and (c) the median-income segment for families earning 5 to 6 minimum salaries.

During its 22 year life, the National Housing Bank financed the purchase of approximately 4.8 million new houses or approximately $25 \%$ of the increase in housing units in the period between 1964 and 1986 (Souza 1999). Only one third of the housing production was targeted to families earning less than 5 minimum salaries, with the rest of it going to the median-income segment, which was expanded to families with up to 12 minimum salaries.

By the early 1980s, the economic recession and inflation negatively affected structural elements of the housing finance system in two ways. First, the funding of the system diminished significantly due to unemployment and the use of some of the 
resources to finance the internal debt. Second, the financial sustainability of the system was affected by the high delinquency rate of the mortgages, which reached more than $50 \%$ in 1984 , due to the decrease in purchasing power of the minimum salary and the indexation of the mortgage payments (Souza 1999). In 1986 the National Housing Bank was extinct and housing finance became practically unavailable to the majority of households until 2004, when macroeconomic conditions, such as low inflation, reduced interest rates, and changes in the regulatory framework, allowed a significant increase in housing finance.

Reforms to the housing sector implemented in the 1960s failed to provide low-income households a formal housing solution. On the other hand, the collapse of the system in the 1980 s and the long period of economic instability that followed, left even households in the low to middle income segment of the market with access to a formal housing solution. As a consequence, the informal housing sector continued to grow rapidly since the 1960 s.

\section{Urban Policy}

To contain the growth of informal settlements, the military regime that took power in 1964 reformed legislation and provided incentives at the federal level to force municipalities to plan and control urban development in their territories and stop the growth of informal settlements. In 1979, a federal law to regulate land subdivision was approved, in substitution of the Federal Decrees 58 of 1937 and 271 of 1967. 
Federal Law 6,766 of 1979 required land subdivisions to have a minimum plot size of 125 square meters with minimum frontage of 5 meters and a compulsory donation by the landowner of $35 \%$ of land for public use such as streets, parks and areas for public equipments. ${ }^{4}$ These parameters could be relaxed in specific urbanization projects or to build public housing. All land subdivisions were required to be developed within the urban area boundary set by municipalities ${ }^{5}$ and outside areas that were environmentally fragile. Finally, all land subdivisions were required to be registered in the real estate public notary. In order to be registered, they were required to have a municipal permit and had to have executed minimum construction works certified by the local authority. The construction works were defined as the execution of the streets (not pavement), demarcation of the plots and public spaces, and execution of a solution for the drainage of pluvial water.

In 1999, Federal Law 6,766/79 was revised by Federal Law 9,785/99. The new law transferred to the municipalities, authority to determine the percentage of compulsory

\footnotetext{
${ }^{4}$ Previous legislation didn't specify a minimum plot size and frontage and municipalities could define their own parameters. Compulsory donation of 35\% of the area was revised in 1999 by Federal Law 9,785/99, when municipalities were allowed to define their own parameters for compulsory donation.
}

\footnotetext{
${ }^{5}$ The tax code of 1967 required municipalities to designate urban and rural areas of their territory for the purpose of applying: (a) urban property taxes (IPTU) in urban areas and in areas subjected to urban expansion; and (b) rural property taxes (ITR) in rural areas. Later, Federal Law 6,766/79 made it illegal for developments outside of the urban area or the area of urban expansion to be subdivided and commercialized for residential use.
} 
donation of land for public use. It expanded the requirements of minimum construction works that subdivisions had to have in order to be registered, including the drainage of pluvial water, public lighting, sewage systems, access to water and electricity by each residence, and the execution of streets (not pavement).

Federal Law 6,766/79, with the changes provided by Federal Law 9,785/99, is still being applied in Brazil. Most municipalities approved land subdivision and zoning regulations that use parameters that are far more stringent than those at the federal level. However, as Maricato (1996) points out, one of the innovations of the federal legislation was to criminalize developers of clandestine or irregular land subdivisions with the objective of stopping the practice.

For several reasons the legislation was not successful in stopping irregular or clandestine land subdivisions or the informal housing sector in general. In some cities, such as in Sao Paulo, there was a reduction in the supply of clandestine or irregular subdivisions in the years after the approval of Federal law 6,766. However, the city experienced an explosion in the growth of favelas in the 1980s and 1990s. While in 1973, the city of Sao Paulo had 100,000 people living in favelas, this number increased to almost 2 million by 1993 (Tashner 2003).

The other attempt of the military regime to contain the growth of the informal housing sector was to use incentives to encourage municipalities to better plan the growth of the territory. In the 1970s and early 1980s, the National Housing Bank 
increased the investment in urban development projects, such as water and sewage infrastructure, and required municipalities to have master plans in order to have access to those resources. From 1969 to 1978 the National Housing Bank's investment in urban development projects grew from $4.1 \%$ of its total investments to 28\% (Azevedo \& Andrade 1982). By the early 1980s, the investment in this sector represented $0.5 \%$ of the Gross National Product (Melo 1990). The investments in urban development projects improved access to basic infrastructure, but most municipal master plans never became law and in most cases ended up being ignored in the development of cities.

The collapse of the housing finance system in 1986, the lack of affordable formal housing solutions for low and middle income families, and a decrease in income during the recession of the 1980s, resulted in the informal housing market growing despite all efforts to contain it through legislation and planning.

In 1988, with the end of the military regime and the return of democracy, Brazil approved a new Constitution that introduced several innovations in urban development policies. First, it recognized the right to property, requiring real estate to fulfill a social function. Second, it included practical instruments to ensure rights to families living in informal settlements, and made urban regulation more flexible for the regularization of informal settlements and the development of low-income housing. Some examples of these instruments are special legislation for low-income residential developments, special zoning requirements for areas of social interest, and 
the acquisition of domain through "usucapião" (the concession of use of a plot no larger than 250 square meters to a person who doesn't own any other property and has lived on it for five consecutive years).

A study in the state of Sao Paulo (Rolnik 1998) found that the special legislation for low-income residential developments was one of the most used instruments since the approval of the Constitution. The study found that $43 \%$ of the surveyed municipalities have approved special legislation for low-income residential developments, with construction and land use parameters more permissive than those used for all other developments. A special zoning area for low income housing (ZEIS), permitting more permissive land use regulation, was applied in $27 \%$ of the surveyed municipalities.

The use of permissive land use regulation to improve access to land started before the approval of the new Constitution. Recife, a city in the northeast, was one of the first to create ZEIS in 1983. However, the inclusion of these instruments in the Constitution contributed to the expanded use of these instruments in more municipalities.

Another important change in the Constitution of 1988 was the consolidation of fiscal decentralization that started in the mid 1980s. While in 1980 the federal government had $66.2 \%$ of the total public resources of the country, the states had $24.3 \%$ and municipalities had 9.5\%; in 1992, the municipalities increased their participation in 
the amount of public resources to $16.9 \%$, states increased their participation to $31.0 \%$ and the federal government reduced its share to 52.2\% (Rezende 1997).

A secondary effect of the increase in transfers from the federal government to state and municipal governments was the creation of new states and municipalities. Between 1988 and 2000, the number of states increased from 21 to 26, which represent a $25 \%$ increase, and the number of municipalities grew from 4,128 to 5,559, which represent a 35\% increase (Alves 2006). In 1996, Constitutional Amendment $15 / 96$ slowed this trend considerably, by reserving to the federal government, the power to create new municipalities. In the state of Parana, 81 municipalities were created between 1988 and 1996, but none was created after the amendment to the Constitution.

The fiscal decentralization created a major shift in the role of the different levels of government in urban development. The increase in transfers left the federal government with few resources to have a coordinated program of investment in urban development. Instead, the resources were spread among 5,000 municipalities, which became the main level of government responsible for urban development. The consolidated annual expenditures of municipal governments in housing and urban planning in Brazil grew from US\$2.6 billion in 1988 to US\$4.0 billion in 1992, while expenditures in health and sanitation grew from US\$1.5 billion in 1988 to US\$2.1 billion in 1992 (Rezende 1997). There is an ongoing debate about whether Brazilian decentralization went too far and more resources should have remained in the hands 
of the federal government, but the fact is that since 1988, municipalities and to some degree states, are the main actors in the formulation of urban policies and the execution of urban programs.

Another change brought about by the Constitution of 1988 was the requirement that municipalities with more than 20,000 inhabitants legislatively approve a master plan. This requirement was not enforced and a minority of municipalities complied. A study of the impact of the Constitution's new provisions on urban development in municipalities in the state of Sao Paulo found that $40 \%$ of surveyed municipalities with more than 20,000 inhabitants didn't have an approved master plan, 10 years after the approval of the Constitution (Rolnik 1998).

In 2001, Federal Law 10,257, also known as the City Statute, detailed several aspects of the Constitution with respect to urban policies. This is the first law on urban policy in Brazil, and is acclaimed for acknowledging the existence of the informal sector and for proposing instruments for the regularization and/or development of areas occupied by low-income households. The law listed 35 instruments municipalities could use as part of their urban policies, regulating eleven of these instruments, such as the master plan, progressive urban property taxes, and ZEIS.

After the approval of the City Statute, there was significant effort at the federal level to have municipalities comply with the requirement to approve a master plan and to make it the centerpiece in regulating, planning, and managing their territories. In 
2006, of the 1,682 municipalities that were required to approve a master plan, $67.2 \%$ complied, $29.3 \%$ were in the process of reviewing their master plans and only $3.6 \%$ didn't initiate the process (Cymbalista 2006). Several municipalities used the opportunity to review their zoning and land subdivision regulations, their construction code, and include the new instruments proposed by the Constitution and the City Statute.

In conclusion, in the 1980s there was a major shift in the formulation of urban policies in Brazil. The centralization of housing and urban development policies that characterized the military regime was replaced by decentralization of responsibility and resources to municipalities. Prior legislation and policies had avoided confronting the underlying problems of informal settlements, and had tried to merely stop their development and replace them with formal housing solutions. In the 1980s there was a recognition that the problem was too big to ignore and that informal settlements could not be eradicated and replaced, but needed to be recognized and regularized. Finally, new legislation provided instruments to make land use regulation more permissive in order to make housing more affordable to low income families.

Now that municipalities are at the center of urban policy, and legislation at the federal level encourages municipalities to review their land use regulation and make it less stringent, the question is: does a more permissive land use regulation reduce the price of formal housing price and decrease the growth of the informal housing sector? This 
is the central question that this study will address by looking at the case of the metropolitan area in Curitiba.

\section{The Metropolitan Area of Curitiba}

The metropolitan area of Curitiba is located in the state of Parana, in the south of Brazil. It was originally created in 1974 with 14 municipalities but its limits have been expanded in the 1990s to include 26 municipalities. The current metropolitan area has $15.5 \mathrm{~km}^{2}$, borders the state of Sao Paulo to its north and the state of Santa Catarina to its south, has a population of approximately 2.8 million ( $29 \%$ of the state population, according to the 2000 census), and accounts for $41.5 \%$ of Parana's economy (COMEC 2006).

The metropolitan region is generally divided in three parts: Curitiba and the first ring - also known as the metropolitan urban agglomeration, the second ring, and the third ring. Figure 6 shows in yellow the urban agglomeration, in dark brown the first ring, in medium brown the second ring and in beige the third ring of the metropolitan area of Curitiba. 


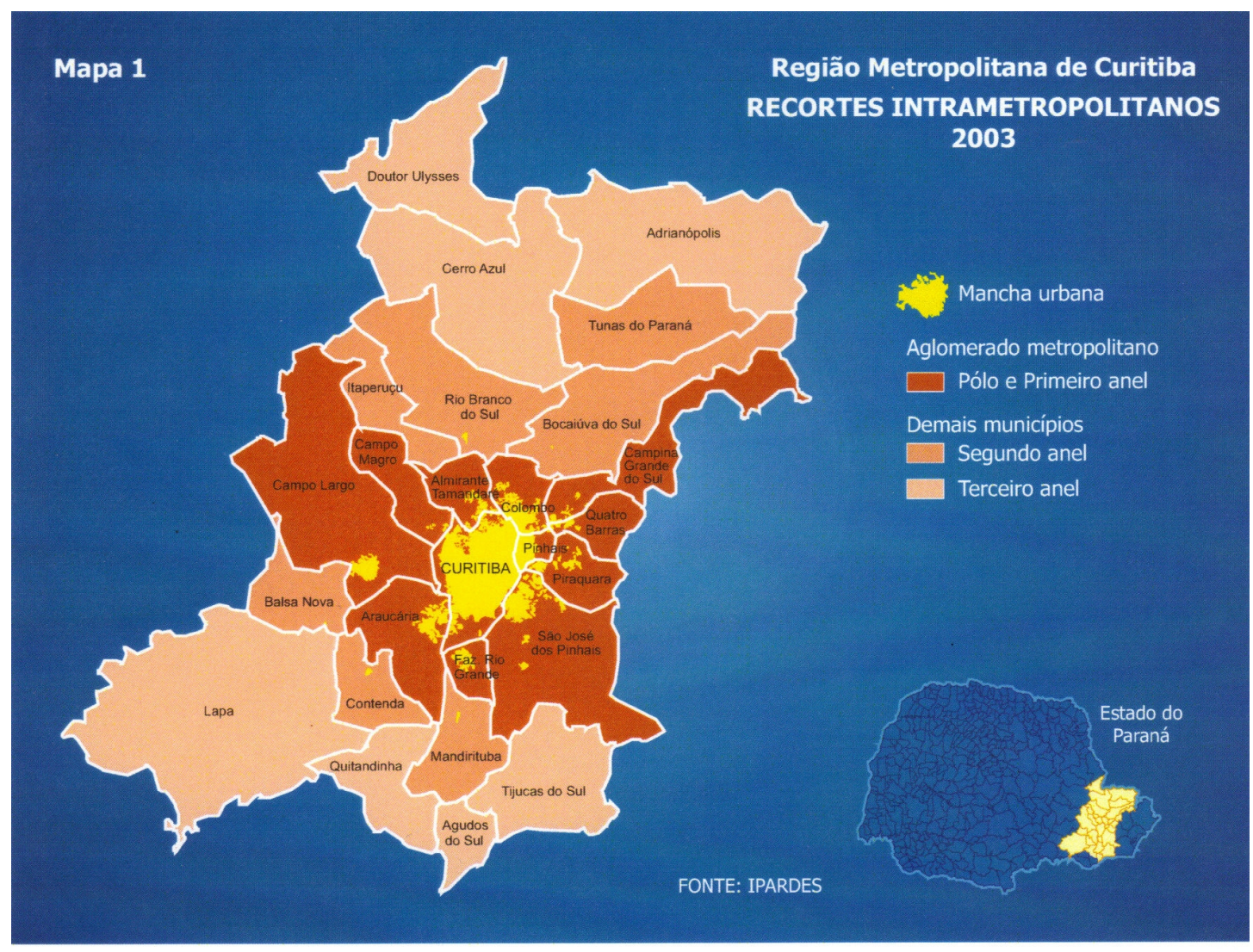

Figure 6 - The Metropolitan Area of Curitiba

Source: IPARDES

While the economic transformation of the southeast and especially of Sao Paulo started in the 1950s, Parana's major transformation started in the 1970s. The agriculture sector was transformed by the progressive expansion, modernization, diversification, and development of an agro-industry; and the industrial sector was impacted by the introduction of modern metal mechanic industries, as part of the process of spatial deconcentration from the metropolitan area of Sao Paulo (Nojima et al. 2004).

As the metropolitan area of Sao Paulo, with its 15.4 million habitants in 1991, was becoming less attractive to new investments because of the exhaustion of its 
infrastructure capacity and decrease in quality of life, industries were gradually moving out to, among other areas, the state of Parana. In the 1990s, the industrialization of the state of Parana gained momentum with the attraction of large international companies, such as Renault (with investments of US\$1.12 billion), Volkswagen/Audi (US\$750 million), and Chrysler (US\$315 million). This expansion was possible because of a period of economic stability in the country as a whole, a state policy of fiscal incentives, strategic location advantages such as the proximity to Sao Paulo and the port of Paranagua, and the state's investment in modern infrastructure in energy, telecommunication, and transportation, among others (Nojima et al. 2004).

The expansion of the industrial base of the 1990s particularly benefited the metropolitan area, where most new industrial investment and expansion took place. This was specially the case of Sao Jose dos Pinhais, where Renault and Volkswagen/Audi located, Campo Largo, where Chrysler located, Araucaria, where a major oil refinery was built in the previous decade, and the city of Curitiba, where many of the industries continue to concentrate in its industrial district.

Between 1970 and 2000, the metropolitan area increased significantly its contribution to the economy of Parana, raising its share in the state's Added Fiscal Value (VAF) from $17 \%$ in 1975 to $43 \%$ in 2000 . Economic activity was concentrated in the city of Curitiba and the municipalities that form the first ring of the metropolitan area. That area increased their share of the VAF from 16\% in 1975 to $41 \%$ in 2000. 
It is important to note that the first ring grew at a much higher rate than Curitiba, increasing its share of the state's VAF from $2 \%$ in 1975 to $21 \%$ in 2000 . These numbers show an economic trend of industrial deconcentration from Curitiba to the neighboring municipalities, while Curitiba is expanding its service and commercial sectors.

Table 1 - Share in the State of Parana's Added Fiscal Value 1975-2000

\begin{tabular}{|c|c|c|c|c|c|c|}
\hline \multirow[t]{2}{*}{ Area } & \multicolumn{6}{|c|}{ Percentage of Total Added Fiscal Value } \\
\hline & 1975 & 1980 & 1985 & 1989 & 1996 & 2000 \\
\hline Metropolitan Urban Agglomeration & 15.57 & 31.91 & 27.54 & 35.31 & 38.37 & 41.12 \\
\hline Curitiba & 13.47 & 15.76 & 15.62 & 23.21 & 25.67 & 19.89 \\
\hline First Ring & 2.09 & 16.14 & 11.92 & 12.10 & 12.70 & 21.23 \\
\hline Second Ring & 1.12 & 1.11 & 1.10 & 1.30 & 1.31 & 1.51 \\
\hline Third Ring & 0.37 & 0.47 & 0.50 & 0.41 & 0.41 & 0.41 \\
\hline TOTAL Curitiba Metropolitan Area & 17.06 & 33.48 & 29.10 & 37.02 & 40.09 & 43.04 \\
\hline
\end{tabular}

Source: Nojima et al. 2004

The economic growth of the metropolitan area of Curitiba since the 1970s was accompanied by a rapid growth of its population. Since the 1970s, the metropolitan area of Curitiba has been growing at a faster rate than most metropolitan areas in Brazil. Between 1970 and 1991 the population of the metropolitan area more than doubled in size, increasing from 869,837 to $2,003,015$, respectively constituting $12.5 \%$ and $23.7 \%$ of the state of Parana's population. In 2000, the region reached 2,768,394, which corresponds to $28.9 \%$ of Parana's population.

While in the 1980s and 1990s most metropolitan areas in Brazil had a significant reduction in the rate of growth of their population, the metropolitan area of Curitiba maintained one of the highest rates of growth in the period. Between 1970 and 1980, the population in all metropolitan areas in Brazil grew at 3.9\% annually, while in 
Curitiba it grew at 5.4\%. Between 1980 and 1991, the rate of growth of all metropolitan areas of Brazil was reduced to $1.9 \%$ a year, while in the metropolitan area of Curitiba the rate was reduced to $2.9 \%$, increasing again to an annual growth of $3.1 \%$ in the period between 1991 and 2000.

The majority of the population is still concentrated in the city of Curitiba, where 1.5 million people or $57.3 \%$ of the population of the metropolitan area lived in 2000 . The municipalities that form the first ring of the metropolitan area had a total population of 972,000 people or $35 \%$ of the population of the metropolitan in 2000 .

Table 2 - Annual Rate of Population Growth in the Metropolitan Area of Curitiba 1970-2000

\begin{tabular}{|l|r|r|r|}
\hline Area & $\mathbf{1 9 7 0 - 1 9 8 0}$ & $\mathbf{1 9 8 0 - 1 9 9 1}$ & $\mathbf{1 9 9 1 - 2 0 0 0}$ \\
\hline Curitiba & 5.21 & 2.27 & 2.13 \\
\hline First Ring & 8.06 & 4.79 & 5.44 \\
\hline Second Ring & 2.05 & 3.30 & 2.60 \\
\hline Third Ring & 0.58 & 0.54 & 0.80 \\
\hline TOTAL Metropolitan Area of Curitiba & 5.40 & 2.91 & 3.14 \\
\hline
\end{tabular}

Source: IPARDES 2005

The Informal Housing Sector

It is very hard to find a study that focuses on the characterization and evolution of the informal housing sector in more than one municipality. Some municipalities, such as Curitiba, have made it a priority to collect data on the informal housing sector in order to define housing policies, but each municipality has used different periods, definitions and methodologies, making comparison of the data difficult. 
A recent study of the evolution of the informal housing market in the metropolitan area of Curitiba conducted by the World Bank in 2004 attempted to fill this gap (Serra et al. 2005). The study used previous studies, the database of municipalities and public agencies, and the World Bank's own data collection to get information about clandestine and/or irregular land development (loteamentos) and squatter settlements (favelas) in 13 municipalities in the metropolitan area of Curitiba. The World Bank study area includes Curitiba and the 11 municipalities in the first metropolitan ring that collectively form the metropolitan agglomeration of Curitiba as was described above. In addition, the World Bank study also includes Mandirituba, a municipality that used to be part of the first ring, until Fazenda Rio Grande's emancipation in $1990 .^{6}$

According to the World Bank study, the area had a total of 896 informal housing settlements with 100,121 households in $2004-13.3 \%$ of the total number of households in the area. This number is much bigger than the estimates of the census, using either the definition of subnormal agglomerations (a group of 50 or more residences built with temporary materials - shacks - located in a settlement that presents a disorganized pattern of occupation and lacks essential public services) or irregular housing (houses where the occupant owns the title to the house but not

\footnotetext{
${ }^{6}$ Until 1990, Mandirituba was part of the first metropolitan ring. However, in 1990, the north portion of the municipality of Mandirituba, which borders the city of Curitiba, separated from Mandirituba and the municipality of Fazenda Rio Grande was created. As it was included in the World Bank study, this dissertation also includes Mandirituba as part of the study area.
} 
land). According to the census, the area had 44,509 houses in subnormal agglomerations in 2000 or $6.1 \%$ of the stock of houses, and 52,973 irregular houses in 2000 or $7.2 \%$ of the stock of houses.

The World Bank study found that $56.5 \%$ of informal housing is in favelas, while 43.5\% are in irregular/clandestine subdivisions. It also found that informal settlements in the area are relatively small. The median size of an informal settlement in Curitiba has 40 houses, while in Recife it has 250 houses. In Curitiba, $57.1 \%$ of informal settlements are small, with less than 50 houses; $38.4 \%$ are medium-size, with 51 to 500 houses; and only $4.5 \%$ are large, with 501 houses or more. The large number of small settlements might explain in part the census' lower number for houses in subnormal agglomeration, since the census only considers settlements with more than 50 houses.

In terms of the period of formation of the informal settlements in the area, the World Bank study found that the majority of them were formed in the 1980s and 1990s. According to the study, $72.1 \%$ of the informal settlements were formed in the $1980 \mathrm{~s}$ and 1990s, 13.6\% were formed before 1980, and 14.3\% were formed since 2000 . Finally, the World Bank study found that the majority of informal settlements were located on public land. According to the study, $46.9 \%$ of informal settlements were located on public land, $37.5 \%$ were located on private land, and $15.6 \%$ were located on land with a mix of public and private ownership. 
The data confirms that informality is a problem in the metropolitan area of Curitiba. However, in comparison with other Brazilian cities, the size of the informal housing sector in Curitiba is relatively small. The data also confirms that the census underestimates the number of houses in the informal sector, something authors have found in other Brazilian cities. Because the methodology is the same for all municipalities it can be assumed that the underestimation is of the same order for all localities, thus controlling for distortion of the results of the present study. Finally, the data shows that informal settlements are relatively small in the metropolitan area of Curitiba and might not be captured by the census measure of subnormal agglomerations, which would favor the use of the other census measure of informal housing (houses where the occupant owns the house but doesn't have a title to the land).

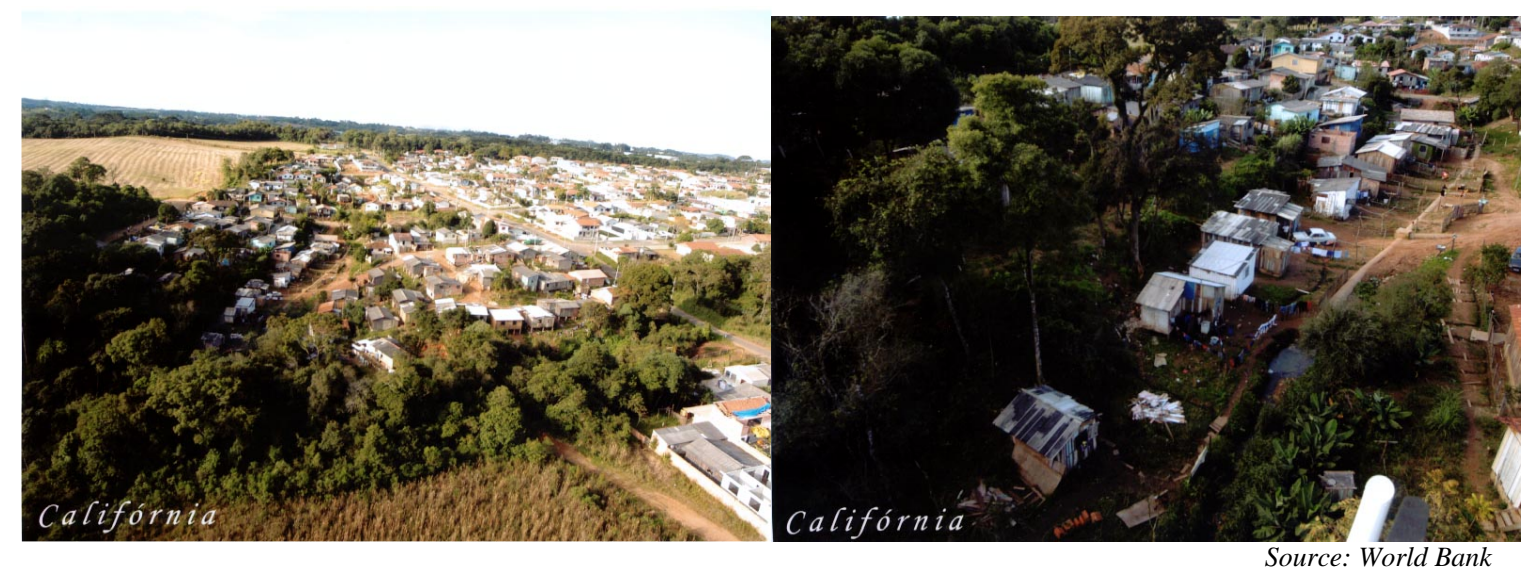

Figure 7 - Irregular Land Subdivision California, Araucaria 


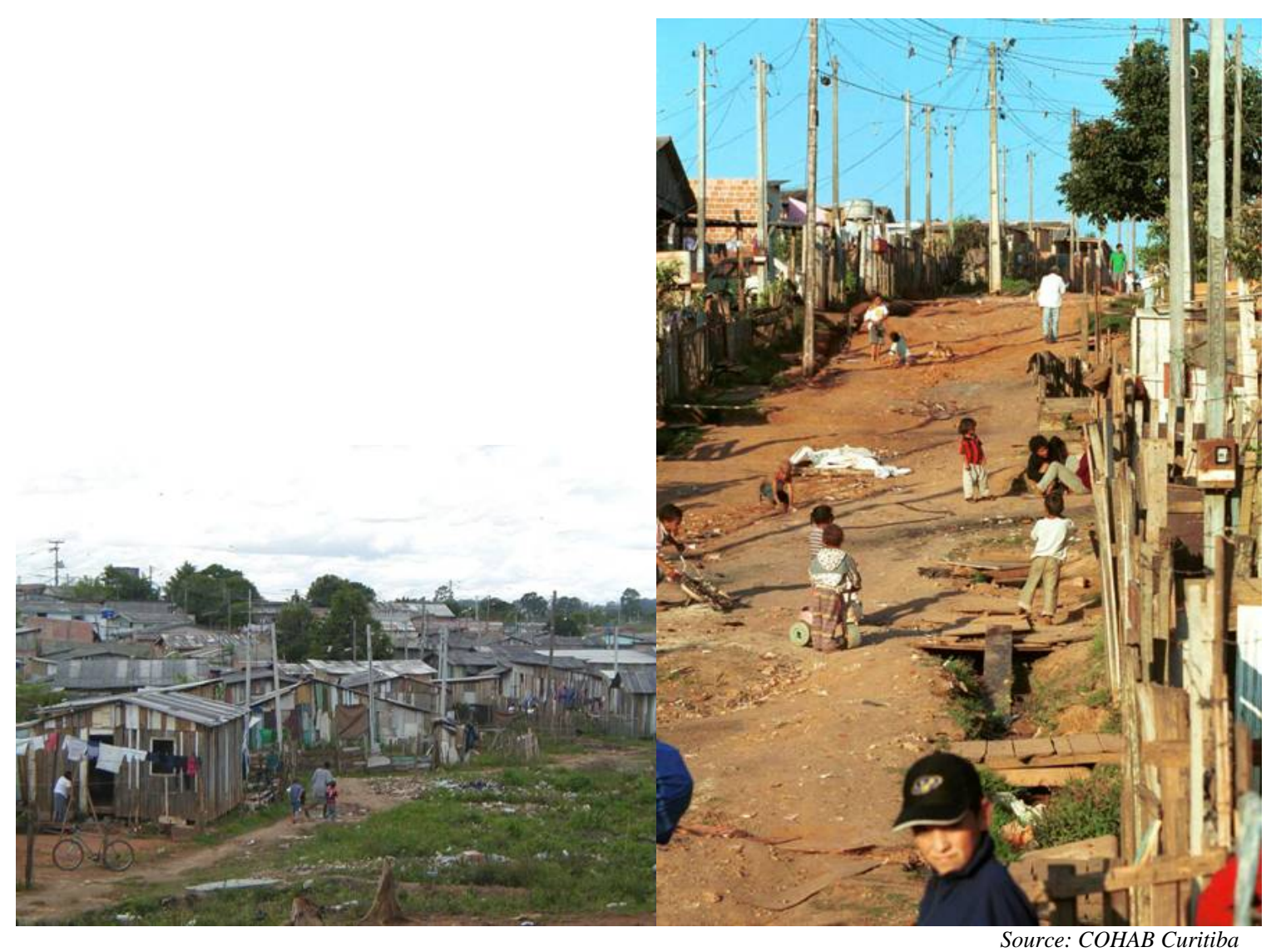

Figure 8 - Favelas Pantanal and Bela Vista, Curitiba

\section{Urban Planning in the Study Area}

Municipal Legislation in the Study Area

The present study adopts the study area defined by the World Bank's assessment of urban land markets in Curitiba. The study selected the metropolitan area limited by the commuting distance, defined as the distance in which a family could look for housing in the next ten years. It comprises thirteen municipalities ${ }^{7}$, covers $2,082 \mathrm{~km}^{2}$, and has a population of 2.6 million (Serra et al. 2005).

\footnotetext{
${ }^{7}$ Almirante Tamandare, Araucaria, Campina Grande do Sul, Campo Largo, Campo Magro, Colombo, Fazenda Rio Grande, Pinhais, Piraquara, Quatro Barras, and Sao Jose dos Pinhais.
} 


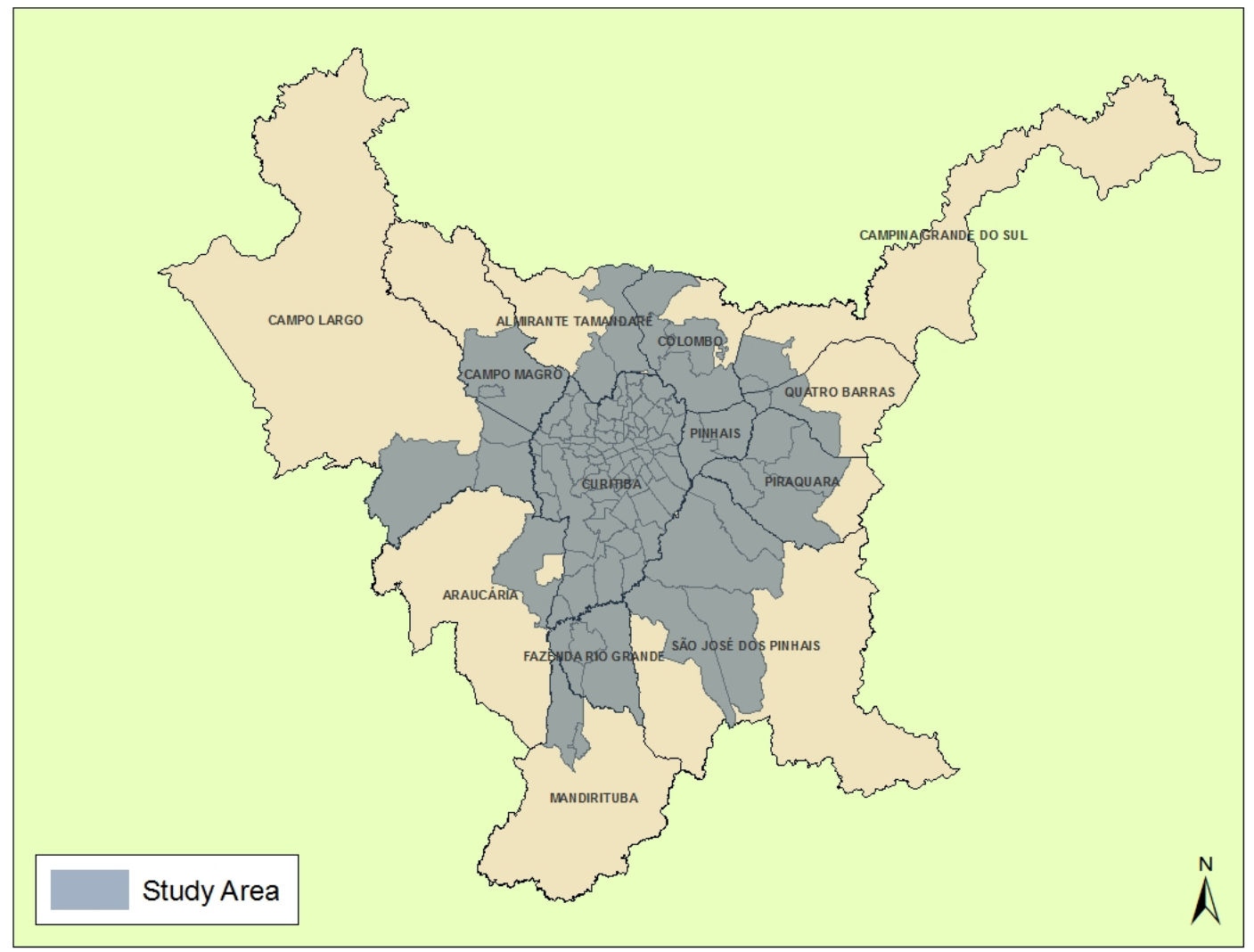

Figure 9 - Municipalities and Study Area

The guiding instrument in urban development in municipalities is the zoning law. Prepared by municipal governments and approved by the municipal legislature, it is also known as the legislation for the use and occupation of land. This legislation guides the use of the territory (such as residential, industrial, commercial, rural, and environmentally protected) and the occupation (such as parameters in terms of the minimum area of a plot of land, the ratio between the build area and the plot area also known as the floor-to-area ratio - and the maximum number of floors). This legislation is not static. It can be, and is, frequently modified by executive decree or municipal law to incorporate revisions to land use and occupation parameters that are applied in specific areas of the territory. 
Municipalities also have additional legislation that applies either to the whole territory or to specific parts, and guides specific aspects of urban development that include land subdivision, building codes, the vial system, and low income housing provisions. After the approval of the City Statute in 2001, most municipalities approved master plan laws that guided the revision of related urban legislation. As will be discussed later, all municipal legislation is subject to the legislation approved at the state and federal levels.

Of the 13 municipalities that are part of the study area, ten had their zoning laws approved in the 1970s and 1980s, although these laws were not rigid and were subjected to modifications throughout the period. Only three of them had zoning laws approved in the 1990s (Sao Jose dos Pinhais in 1992, Fazenda Rio Grande in 1995, and Campo Magro in 1999).

After the approval of the City Statute in 2001, and the efforts of the federal government to encourage municipalities to approve new master plans in accordance with the Constitutional mandate, eleven municipalities in the study area approved new zoning laws between 2000 and 2007 and two of them are in the final stages of revision. Because this research is using the zoning law that was effective in 1999, these new regulations didn't affect this analysis.

As part of this study, the land use regulation of the municipalities included in the study area was researched to find the parameters that were being applied in 1999. The 
Institute of Research and Urban Planning of Curitiba (IPPUC) had the zoning map and all the laws and decrees that affected the zoning regulation for the city of Curitiba. For the other municipalities, two major sources of information were used: the archives of planning departments of each municipality and the archives of the coordinating agency for the metropolitan area of Curitiba (COMEC).

All municipalities in the study area have zoning laws, most of them dating back to the 1970s and 1980s. Curitiba has the oldest zoning regulation dating from 1975 (Municipal Law 5,234/75). The main alteration to this zoning law was put into effect in 1981, when Municipal Law 6,204/81 modified the land use regulation of the industrial district. Apart from this modification, most changes to the land use regulation between 1975 and 1999 were localized, so the 1975 zoning law was for the most part applied for 25 years, until the city approved a new zoning law in 2000 (Municipal Law 9.800/2000).

The municipalities of Campo Largo, Colombo and Quatro Barras had zoning regulations dating from the late 1970s. Campo Largo approved a zoning regulation in 1978 with Municipal Law 444/78 to which no major modification was approved until 2007.

In Colombo, the zoning regulation was established in 1978 by Municipal Law 32/78. The municipality approved changes to specific zones, but the main parameters were maintained until a new zoning law was approved in 2004. 
Quatro Barras approved a zoning regulation in 1979 with Municipal Law 09/79. Most modifications to the zoning regulation made after 1979 were localized, affecting a small proportion of the territory. In 2000 the municipality drafted a new zoning regulation, but as recently as when I collected my data, in November of 2007, the new zoning law was being reviewed and had not been approved.

Almirante Tamandare, Araucaria, Campina Grande do Sul, Mandirituba, Pinhais, and Piraquara had zoning regulations approved in the early 1980s. Almirante Tamandare's zoning regulation was established in 1981 by Municipal Law 59/81, with some modifications adopted in 1996, with the approval of Municipal Law 430/96. A major change to the zoning regulation came about only with the approval of a new zoning law in 2006.

Araucaria's zoning regulation was established in 1981 by Municipal Law 584/81, with the incorporation of some additional zoning uses in 1996 by Municipal Law 1,047/96. In 2006 the municipality prepared a new zoning regulation, but its content was put under revision and the until the time of data collection in November of 2007 the city was in a state of limbo, with no zoning regulation in effect. All land development permit applications were being reviewed by the planning commission on a case-by-case basis.

Campina Grande do Sul's zoning regulation was established in 1980 by Municipal Law 12/80, with some subsequent laws $(12 / 93,7 / 94,3 / 96,11 / 96,18 / 96,31 / 97$, and 
2/98) modifying localized areas but maintaining the main parameters of the regulation. A new zoning regulation was approved only in 2006.

Mandirituba's zoning regulation was established in 1983 by Municipal Law 25/83. Parameters of the zoning regulation were later altered in 1995 by Municipal Law $58 / 95$ and that is the law that was still in use during the time of data collection in 2007, although the municipality was in the process of reviewing and proposing a new zoning law.

Pinhais was a municipality created in 1992, from Piraquara. The municipality adopted the zoning regulation approved in 1980 by the municipality of Piraquara with Law 19/80, which established the zoning regulation for the district of Pinhais. Several laws altered specific aspects of the zoning regulation, but the major change only came in 2001, with the approval of a new zoning law.

Piraquara's zoning regulation was established in 1980 by Municipal Law 12/80. In the following years, some municipal laws expanded the urban area, created new zoning areas and changed some parameters of the zoning regulation (Municipal Laws $33 / 81,62 / 82$, and 251/95) but the major change to the zoning regulation came in 2007, with the approval of a new zoning law.

There are three municipalities whose zoning laws were established in the 1990s: Campo Magro, Fazenda Rio Grande, and Sao Jose dos Pinhais. Campo Magro is a 
municipality created in 1995 from the municipality of Almirante Tamandare. In 1999, Parana's state legislature approved State Decree 1,611/99, creating the Territorial Planning Unit (UTP) of Campo Magro, which became the zoning regulation for the municipality, and is currently in force.

Fazenda Rio Grande is a municipality created in 1990 from Mandirituba. Its zoning regulation was established in 1995, with the approval of Municipal Law 70/95. This law left out the land use parameters, which were included by Municipal Decree 107/95. Later, Decrees 143/96 and 216/1998 modified the parameters of some zoning areas but the major change came with the approval of a new zoning law in 2006.

Sao Jose dos Pinhais' zoning regulation was established in 1992 by Municipal Law 10/92. In 1996, Municipal Laws 03/96 and 101/96 established the Industrial District for Renault and changed some land use parameters in this district. In 1997, Municipal Law 01/97, 35/97, and 60/97 established the Industrial District for Audi and changed land use parameters in this district. These were the major changes to the zoning regulation until 2005, when a new zoning regulation was approved. 
Table 3 - Summary of Main Zoning Laws in the Study Area

\begin{tabular}{|l|l|l|l|l|}
\hline Municipality & $\begin{array}{l}\text { Main zoning law } \\
\text { effective in 1999 }\end{array}$ & $\begin{array}{l}\text { Year of } \\
\text { approval }\end{array}$ & $\begin{array}{l}\text { New law } \\
\text { approved since } \\
\text { then? }\end{array}$ & $\begin{array}{l}\text { Year of } \\
\text { approval }\end{array}$ \\
\hline Curitiba & Municipal Law 5234 & 1975 & Yes & 2000 \\
\hline Colombo & Municipal Law 32 & 1978 & Yes & 2004 \\
\hline Campo Largo & Municipal Law 444 & 1978 & Yes & 2007 \\
\hline Quatro Barras & Municipal Law 09 & 1979 & No & \\
\hline Campina Grande do Sul & Municipal Law 12 & 1980 & Yes & 2006 \\
\hline Pinhais & $\begin{array}{l}\text { Piraquara Municipal } \\
\text { Law 19 }\end{array}$ & 1980 & Yes & 2001 \\
\hline Piraquara & Municipal Law 12 & 1980 & Yes & 2007 \\
\hline Almirante Tamandare & Municipal Law 59 & 1981 & Yes & 2006 \\
\hline Araucaria & Municipal Law 584 & 1981 & No & \\
\hline Mandirituba & Municipal Law 25 & 1983 & No & 2005 \\
\hline Sao Jose dos Pinhais & Municipal Law 10 & 1992 & Yes & 2006 \\
\hline Fazenda Rio Grande & $\begin{array}{l}\text { Municipal Law 70 and } \\
\text { Municipal Decree 107 }\end{array}$ & 1995 & Yes & \\
\hline Campo Magro & State Decree 1611 & 1999 & No & \\
\hline
\end{tabular}

State Legislation for the Metropolitan Area of Curitiba

A legal and institutional framework for the administration of metropolitan regions was first established with the Constitution of 1967, during the military regime. As explained before, that period was characterized by the creation of integrated and centralized planning institutions in all areas of government, and planning of the territory was seen as a key element to induce social and economic development.

With the end of the military regime and the return to democracy, the metropolitan entities lost political and financial support and some disappeared. Recently, some states have renewed their interest in metropolitan planning, especially after the approval in 2001 of the federal law on urban policy, the City Statute.

In the state of Parana, an institutional framework was created in 1974 to manage policies of the metropolitan region of Curitiba. COMEC - Coordination of the 
Metropolitan Region of Curitiba, was created to plan and execute policies for the metropolitan region. Two councils with representatives from the state, Curitiba, and the other municipalities of the metropolitan region, were created to review and approve policies; and a state department was created to provide technical support.

This structure was active in the late 1970s and early 1980s in the formulation of integrated plans and the proposal of priorities in terms of transportation and infrastructure investments. Following the national trend, COMEC lost most of its political support during the late 80 s and early 90 s and almost became extinct.

In the late 1990s, policies focusing on environmental sustainability gained political support and the state of Parana approved a number of laws to improve watershed management. With the new policy priorities, COMEC started to be more active in the revision of local zoning laws that affected areas protected by the new laws.

One of the main legislative efforts that affected watershed areas in the metropolitan area of Curitiba was State Law 12,248 of 1998, which created the integrated system for watershed management and protection in the metropolitan area of Curitiba. This law proposed the creation of Territorial Planning Units (UTP) to define parameters for land use and occupation in areas affecting watersheds. Municipalities had to then incorporate these new parameters to their zoning laws. 
UTPs had four different major zoning areas: (a) restricted occupation, (b) guided occupation, (c) consolidated occupation, and (d) rural. In consolidated areas, the parameters for land use and occupation were generally similar to those in the municipal zoning, with minimum plot size varying between 360 to 450 square meters and occupation ratio varying from 50 to $66 \%$. In areas with guided occupation, minimum plot size generally varied between 450 and 10,000 square meters while occupation ratio generally varied between 20 and 50\%. In restricted and rural areas, minimum plot area was generally set at 20,000 square meters.

Since 1998, five UTPs were created and all of them affected the municipalities in the study area. UTP Pinhais was created by State Decrees $808 / 99$ and 4,466/2001 and affected the municipality of Pinhais. UTP Guarituba was created by State Decrees $809 / 99$ and 6,314/2006, and affected the municipalities of Piraquara. UTP Itaqui was created by State Decrees 1,454/99 and affected the municipalities of Piraquara and Sao Jose dos Pinhais. UTP Quatro Barras was created by State Decrees 1,612/99 and affected the municipality of Quatro Barras. UTP Campo Magro was created by State Decrees 1,611/99 and affected the municipality of Campo Magro.

Even before the creation of the system for watershed management and protection, the state was active in passing legislation to preserve areas that were considered of interest for their natural resources. These areas were later defined by Federal Law 
$9,985 / 2000^{8}$ as conservation units. There are two major forms of conservation units: (a) sustainable use, in which a certain degree of use and occupation is permitted; and (b) integral protection, in which there are restrictions for the use or occupation of the area.

The metropolitan area of Curitiba has seven conservation units with integral protection and thirteen conservation units where sustainable use is permitted (COMEC 2006). In the study area, in 1999, there were only three conservation units that were in effect ${ }^{9}$ : (a) Municipal Area of Environmental Protection (APA) of Iguacu in the municipality of Curitiba created by Municipal Decrees 409 of 1991 and 192 of 2000; (b) Municipal APA of Pinhais in the municipality of Pinhais created by Municipal Decree 134 in 1994; and (c) APA of Passauna, created by State Decree 458 in 1991, affecting the municipalities of Almirante Tamandare, Araucaria, Campo Largo, Campo Magro, and Curitiba. All three conservation units are considered of sustainable use, permitting some use, but possessing in general, restrictive parameters of occupation. For instance, in Araucaria the minimum plot area varies from 1,800 to 20,000 square meters, while in Campo Magro it varies from 5,000 to 20,000 square meters.

${ }^{8}$ Federal Law 9,985/2000 created the National System of Natural Conservation Units (SNUC) responsible for establishing the criteria and regulation for the creation, implementation and management of conservation units.

\footnotetext{
${ }^{9}$ There were other conservation units in the study area that were approved before 1999, but only three had a zoning map and land use and occupation parameters defined by that year.
} 


\section{$\underline{\text { Conclusion }}$}

This Chapter discussed the origins of informal housing in Brazil that were associated with a rapid urban growth attracted by the industrialization process in the southeast and with an unequal distribution of income. Due to two reasons, two major forms of informal housing solutions developed: favelas in more centrally located land and irregular or clandestine loteamentos in the periphery of cities. First, it was difficult for cities to absorb the flows of migrants in an orderly pattern and, second, low salaries make formal housing unaffordable to most low and moderate income households.

The centralized housing and urban policies during the military regime were not able to address the problem. The production of public housing was not able to accommodate the housing needs of low and moderate income families and the planning strategies made regulations more restrictive and limited the ability of local governments to target programs to informal settlements. The Constitution of 1988 and federal legislation addressing urban policy broke with past policies and recognized the rights of people living in informal settlements. More power and resources were decentralized to local governments, informal settlements were allowed to receive public investment in infrastructure, and more permissive urban regulations were approved in several municipalities. In this context, it is important to have a better understanding about whether more permissive regulations can make housing more affordable and whether a reduction in housing price can prevent the growth of the informal housing sector and bring more people to the formal market. 
In the metropolitan area of Curitiba, the informal housing sector also developed as a consequence of the rapid urban growth that followed the industrial transformation of the economy, except that this development was experienced during a later period, starting in the 1980s, and the size of the informal sector was smaller than in most parts of the country. From an early period, the cities in the first ring of the metropolitan area started adopting zoning regulations that followed the guidelines of federal legislation. More restrictive regulations were added by the state of Parana to restrict occupation in areas affecting watersheds. In 2000, the area had a long history of established urban regulations and a growing demand for housing due to the acceleration of the industrial decentralization from Sao Paulo to (among other places) Curitiba. The informal housing sector was growing as consequence of this process. The combination of these trends made Curitiba a good study case for the analysis of the effect of regulation on housing price and informality. 


\section{Chapter 2: Literature Review}

Land use regulation, housing price and informality has been studied by two distinct bodies of literature. The first is the literature that has attempted to measure the cost and, to a lesser extent, the benefits of urban regulation and its effect on housing price. The second is the literature that has tried to understand the operation of the informal housing market. Each is discussed below.

\section{The Effect of Land Use Regulation on Housing Price}

There are extensive writings on the effect of land use regulation on housing price in developed countries. In the United States, Fischel (1990) is an often cited review of empirical work on the subject, while Quigley and Rosenthal (2005) is one of the most recent. Literature focusing on developing countries is more difficult to find. Malpezzi (1999) has a review that covers developed, developing and countries with transitional economies, while Buckley and Kalarickal (2005) include the subject as part of a broader review of housing policies in developing countries.

The literature on the effect of land use regulation on housing price in developing countries can be divided in two major groups: the ones that focus on a specific city or country, and the ones that focus on a comparison of countries. This section presents a summary of these approaches and discusses some of the ways in which land use 
regulation has been defined and measured. For a summary of the literature review in this section, see Appendix I.

\section{City or Country Specific Studies}

The studies that are focused on specific cities or countries generally try to investigate the cost and in some cases the benefits of a particular regulation or set of regulations. Trying to establish a typology of this literature is very difficult, since there aren't that many studies and the ones that exist focus on a variety of regulations and employ a variety of methods. Table 4 provides a summary of measures and methods employed in this literature.

Table 4 - Summary of Regulatory Measures and Methods

\begin{tabular}{|l|l|l|l|}
\hline Method & Regulatory Measure & Scale & Authors \\
\hline Theoretical/Simulation & $\begin{array}{l}\text { Specific regulations or set of regulations: Floor- } \\
\text { to-Area ratio (FAR), Apartheid land use } \\
\text { restriction }\end{array}$ & City specific & $\begin{array}{l}\text { Bertaud and Brueckner (2004); } \\
\text { Bertaud, Buckley and Owens } \\
\text { (2003); Brueckner (1996) }\end{array}$ \\
\hline $\begin{array}{l}\text { Description of } \\
\text { observed housing } \\
\text { and/or land prices and } \\
\text { land use patterns }\end{array}$ & $\begin{array}{l}\text { Specific regulation or set of regulations: FAR, } \\
\text { Special Area of Social Interest (AEIS), } \\
\text { government permission to land conversion from } \\
\text { rural to urban }\end{array}$ & $\begin{array}{l}\text { Country and } \\
\text { city specific }\end{array}$ & $\begin{array}{l}\text { Hereda et al (1997); Somekh } \\
\text { (1999); Bertaud (1996); } \\
\text { Hannah, Kim and Mills (1993) }\end{array}$ \\
\hline Cost-benefit analysis & $\begin{array}{l}\text { A set of regulations: FAR, percentage of saleable } \\
\text { area, approval time, building code requirements }\end{array}$ & $\begin{array}{l}\text { Country } \\
\text { specific }\end{array}$ & $\begin{array}{l}\text { Bertaud and Malpezzi (2001); } \\
\text { Malpezzi and Mayo (1997) }\end{array}$ \\
\hline Regression analysis & $\begin{array}{l}\text { Level of restrictiveness (or alternatively enabling) } \\
\text { of regulatory environment }\end{array}$ & $\begin{array}{l}\text { Cross } \\
\text { country } \\
\text { comparison }\end{array}$ & $\begin{array}{l}\text { Angel (2000); Mayo and } \\
\text { Sheppard (1996) }\end{array}$ \\
\hline
\end{tabular}

Regulatory measures can be very specific regulations, like the Floor Area Ratio (FAR), which is determined by dividing the building's total floor area by the area of the plot of land where the building is located. Alternatively, it can be a specific measure that is determined by a set of regulations, such as the percentage of saleable area (the area that can be sold after taking away areas required for public use such as streets, public schools and parks); or the zone defined as Special Area of Social 
Interest (AEIS, for its acronym in Portuguese), which is a zone with less restraining regulatory requirements for the construction of affordable housing or the regularization of informal settlements. In some cases, the studies don't focus on one particular regulation or set of regulations, but in the whole regulatory environment that applies to different aspects of housing development, such as financing, taxation and land use regulation.

The methods of analysis employed in this literature also vary significantly. Bertaud and Malpezzi (2001) use a cost-benefit model to estimate the net effect of several land use and related regulations in Malaysia. Benefits are roughly estimated comparing current regulation to a baseline based on market comparison and "international practice". Their results show that under current regulation for low income developments, only $44 \%$ of the land is saleable and FAR is only 0.23 . As a consequence, developers have a profitability that is $15 \%$ below the baseline of a middle income development. With suggested reduction in road width, elimination of back alleys and reduction of corner setback requirements saleable area rises to 55\% and FAR rises to 0.41 . These changes make profitability rise $17 \%$ in comparison to the baseline of a middle income development.

Studies that use a description of observed housing and/or land prices and land use patterns include Hannah, Kim and Mills (1993), Bertaud (1996), Hereda et al (1997), and Somekh (1999). Hannah, Kim and Mills (1993) analyze housing price series and land use pattern and, in addition, conduct case studies of five Seoul development 
projects to estimate the effect of South Korea limitation on land conversion from rural to urban. Their results show that national housing price rose more than twice as fast as the consumer price index between 1974 and 1980 and land price is the main cause. The share of land for residential use fell from $11.5 \%$ to $8.9 \%$ and residential land per resident decreased 20\% between 1973 and 1988 due to the under-allocation of residential land. Land with infrastructure for residential use was 1.7 to 6.5 times more expensive than raw rural land and the authors interpreted this large difference as a disequilibrium effect due to government undersupply of conversion permission.

Bertaud (1996) also use a descriptive method to analyze the effect of FAR on land prices in Ahmadabad, India. It compares the density and land price profile in Ahmadabad and in cities where land use density is less restrained. The author concludes that FAR restriction distorts land prices, and shows that in most places where land markets operate well, there is a correlation between density and price gradients, while in Ahmadabad there is a discrepancy.

Hereda et al (1997) analyze vacant land prices in Diadema, Brazil, between 1992 and 1996, where more than $50 \%$ of vacant land was designated AEIS in 1993, when a new master plan and zoning was approved. The study confirms the hypothesis that the price of land in industrial areas increased, because of a decrease in supply of vacant land allocated for industrial use, while the price of vacant land in median density zoning areas and in AEIS experienced a decrease in price. Using similar data, 
Somekh (1999) concludes that AEIS designation in Diadema led to a decrease in the price of land.

Green, Malpezzi and Vandell (1994) use a literature review to understand the effect of urban regulation on the price of land and housing in Korea. On the demand side, the review shows that Korea has a rising aggregate demand for housing due to growth in the urban population, household and income. On the supply side, studies found housing to be price inelastic, explaining price rise with rise in demand. In addition to geographical barriers, a main factor explaining inelastic supply of housing is urban regulation and policies affecting land development (limitation on land conversion, green belts, tax on intensive land use) and housing finance (credit constraints to housing finance).

Bertaud and Brueckner (2004) and Bertaud, Buckley and Owens (2003) use a theoretical approach using the standard monocentric-city model to show how FAR restrictions affect land use; and a simulation analysis to predict changes if FAR restriction was removed in Bangalore and Mumbai, India, respectively. The simulation analysis shows that removing FAR restrictions would increase population density near the center of the city, reduce the edge of the city by $2 \mathrm{~km}$ in the case of Bangalore and $4 \mathrm{~km}$ in the case of Mumbai, and, as a result, reduce commuting cost for residents living at the edge. The commuting-cost saving is estimated to range from 3.3 to $5.0 \%$ of per capita income in the case of Bangalore, and $14 \%$ in the case of 
Mumbai. The second study also shows that the cost imposed by FAR requirements is regressive, imposing larger costs on low-income households.

Brueckner (1996) uses a theoretical model based on the urban model developed by Alonso to assess the welfare net effect from removing apartheid land use restrictions in South Africa. Results show that with the removal of apartheid land use restrictions, blacks compete for land close to the employment center, displacing whites. Blacks have welfare gain because of decrease in commuting cost, while whites suffer welfare loss because of longer commutes. Landowners benefit because of an increase in total land rent due to greater competition. Because this gain is greater than whites' losses, there is an aggregate welfare gain from removing apartheid land use restrictions.

Despite the differences in regulatory measures and methods of analysis employed, the studies reviewed have common results. They all conclude that regulations that restrain urban development increase land and housing price and impose costs that exceed their benefits. On the other hand, regulations that permit greater degrees of density for urban development, such as AEIS, reduce the price of land.

One of the limitations of these studies is that they don't provide a statistical estimation of the effect of urban regulation on the price of housing or land. The theoretical and simulation analysis remain hypothetical, in other words they have not been empirically applied. That is not to say that their results are not robust. Brueckner 
(1996) introduces various modifications to the basic model and still gets the same results, while Bertaud and Brueckner (2004) and Bertaud, Buckley and Owens (2003) use conservative assumptions when applying the theoretical model to the simulation analysis of Bangalore and Mumbai. But these analyses are limited by the fact that they have not been empirically tested.

The limitation of cost-benefit analysis is that it takes price and costs as given and ignores general equilibrium effects. As argued by the authors, this analysis is useful to illustrate how actual and very specific regulations affect costs (and hence land and housing price) on specific development projects (Bertaud and Malpezzi 2001: 395). However, to understand how land use regulation affects housing price, it is necessary to control for several demand and supply variables that are ignored in this type of analysis.

Studies that use a description of observed housing and/or land prices and land use patterns are even less specific about the effect of urban regulation on housing price and their results are subject to interpretation. Hannah, Kim and Mills (1993) present data that "suggest" that a substantial part of the increase in housing price is due to the government's tendency to under allocate land to urban residential use. The authors acknowledge that the conclusion that large differences between rural and urban land prices are a result of disequilibrium is a matter of judgment. The same can be said about Bertaud's (1993) conclusion that FAR restriction distorts land prices based on the observed discrepancy between density and price gradients in Ahmadabad. In the 
case of Hereda et. al. (1997) and Somekh (1999), the studies don't control for other factors that affect the price of land, such as neighborhood characteristics and distance to the central area.

\section{Comparative Studies}

The literature on the effect of land use regulation on housing price in developing countries that focus on a comparison of countries, tries to understand how the stringency of the regulatory environment of different countries affect their housing markets. In contrast with city or country specific studies, comparative studies use statistical analyses to estimate the effect of different regulatory environments on the housing market. Also, the comparative studies focus less on a particular regulation or set of regulations. Instead, they assess the regulatory environment as a whole to draw conclusions about its effect on the housing market.

Mayo and Sheppard (1996) use ordinary least squares and autoregressive least squares to find price elasticity of supply for housing in Korea, Malaysia, and Thailand, to test a previously developed theoretical model which predicts that regulatory constraint will reduce price elasticity of housing supply, which in turn may contribute to excessively wide swings in housing prices. The authors also use a recursive model to estimate the change in price over time. Based on a literature review, they qualify South Korea as the most restrictive regulatory environment; Thailand, as the least; and Malaysia as intermediate. Their results show that Malaysia and Korea had low elasticities of supply, while Thailand had high elasticity. The 
recursive model showed that although Korea and Thailand were relatively stable over time, Malaysia had high elasticity in the years immediately after the adoption of more restrictive planning system, but over time supply became less elastic.

Malpezzi and Mayo (1997) use a cost-benefit model using present value analysis as did Bertaud and Malpezzi (2001), to asses the effect of regulation in Malaysia, and a model similar to Mayo and Sheppard's (1996) to compare the elasticity of supply of Malaysia, Korea, Thailand and the United States. The first model estimates the cost of percentage of saleable area, approval time, building code requirements, and regulation encouraging sales to special ethnic groups. The cost-benefit analysis indicates that regulations add about $\$ 4,000$ (Malaysian) to the developer's cost. The cross-country comparison indicates that Malaysia and Korea have inelastic housing supply curves and Thailand has an elastic curve, similar to the United States.

Angel's (2000) book tests whether an enabling housing policy environment ${ }^{10}$ has a positive effect on the performance of the housing sector, using qualitative and quantitative analyses of housing markets and policies around the globe. To measure

\footnotetext{
10 Angel defines an enabling housing policy environment as one that meets each of five criteria: adjudication of property rights in land and housing, development and regulation of housing finance institutions, administration of housing subsidies, provision and maintenance of residential infrastructure, and regulation of land and housing development. The author quantifies any given housing policy regime along one of its five components, and arrives at a composite measure of the degree of enabling of the housing policy regime as a whole - the Enabling Index.
} 
the regulatory environment for urban development, the author develops a Regulatory Regime Index, a composite measure of three variables: permits delay, minimum lot size, and minimum floor area per dwelling. The regulatory index is integrated with indexes that measure other elements of the housing policy environment (property rights regime index, housing finance regime index, housing subsidy index, and residential infrastructure index) and an ordinary least squares regression analysis estimates the effect of this broad index (the enabling index) on a housing price index, a rent price index, and a weighted housing price index. His results show that a more enabling housing policy environment significantly lowers the housing price index in the 45 countries studied. The same applies to the housing rent index and the weighted housing price index in the 38 countries that have little or no rent control.

The comparative studies arrive at similar results observed in the city and country specific studies: a more restrictive regulatory environment reduces price elasticity of housing supply (which may contribute to excessively wide swings in housing prices) and increases housing costs. On the other hand, a more "enabling" regulatory environment, in conjunction with other "enabling" housing policies, lowers housing price and rent.

One of the main shortcomings of these studies is the level of aggregation of their data and of their measures of urban regulation. In Mayo and Sheppard (1996) the measure of regulatory restrictiveness compares a variety of policies such as Korea's centralized planning system of limiting land conversion from rural to urban, and 
limiting growth through greenbelts; Thailand's centralized planning system of guiding rather than controlling development; and Malaysia's newly decentralized planning system. In addition, their model is subject to the same criticism that was addressed to similar models developed earlier, such as the possibility of aggregation bias because of the use of national data; the small size of the sample, which varies between 14 and 16 annual observations; and the model specification. With respect to the last point, Olsen (1987) criticized reduced-form equations where the long-run supply price is the dependent variable and output quantity and input prices are included on the right hand side. He argued that the function should have input prices and the parameters of the production function or output quantity, but not both.

Malpezzi and Mayo's (1997) cost-benefit model based on Bertaud and Malpezzi (2001) is subject to the shortcoming of ignoring general equilibrium effects while the comparison of supply elasticity based on Mayo and Sheppard (1996) has the shortcomings discussed in the previous paragraph.

Angel's (2000) book is such an ambitious study that it is not surprising that it has shortcomings, especially with respect to the limitation on data, which in many cases limits the accuracy of the indices. One limitation is that each country is assessed based on the information of a single metropolitan area. Another problem is the lack of data even on these single metropolitan areas. For the construction of the regulatory regime index, there were several variables for which data was not available, such as the actual percentage of land unavailable to growth. As a result, the index has a very 
limited set of indicators. For the construction of housing price and rent indexes, the author had to apply a crude method for controlling for housing quality. Angel normalized housing and rent price using a construction quality index for each metropolitan area, which is defined as an equally weighted sum of three indicators: permanent structures, quality attributes (the presence of seven attributes such as piped water and electricity in the median-priced houses) and annual median household income. Finally, the regression analysis aggregates not only an already aggregated measure of the regulatory environment for urban development, but all other aspects that affect the production and consumption of housing, making it very hard to assess the extent to which regulation itself is affecting the price of housing in each of these metropolitan areas.

As the review of this body of literature has shown, both city and country specific studies, and comparative studies, have results pointing in the same general direction: restrictive land use regulation increases housing price and imposes net costs. However, this literature is subject to major shortcomings that could affect the results obtained by these studies. First, several studies suffer from the possibility of aggregation bias for housing price and urban regulation measures. Second, research tends to use methodologies that fail to control for other factors that affect the price of housing. Third, most studies don't provide a statistical estimation of the effect of specific land use regulations on the price of housing or land. Finally, all of these studies ignore the possibility of spatial autocorrelation of housing price. 


\section{The Informal Housing Market}

Traditionally, the literature on informal housing markets has focused on the social, political, and technical dimensions of the informal housing sector. Recently, new research has tried to understand the economic dimension of the informal housing market. This section presents a summary of these approaches and the ways in which they have explained the causes of informality and its relationship to urban regulation and housing prices.

\section{Social, Political and Technical Dimensions}

The research that emphasizes the social dimension of the informal housing market tends to focus on the internal structure and operation of the informal sector. For example, De Souza (2002) uses five case studies of squatter settlements in Recife, Brazil to understand the relationship between perception of security and housing consolidation. Pamuk (2000) interviews an informal credit institution that provides credit for land and infrastructure in Trinidad and Tobago to understand how informal institutional arrangements are utilized by squatting communities to solve their land problems. This approach to the study of informal housing markets is important to understanding the way in which it operates. However, because the determinants of informality are a secondary concern of this literature, it provides limited insight in responding to the question of how informality relates to land use regulation and housing price. 
Authors such as Gilbert (1990), Maricato (1996) and Smolka (2003) are part of the research group that have emphasized the political dimension of the informal housing market, focusing on the relationship between informal and formal housing markets and its structural causes. Gilbert (1990) focuses on the costs and benefits of informal self-help ${ }^{11}$ housing in Latin America. Gilbert challenges the view that informality can be explained by capitalist international division of labor. Instead, the author argues that local factors such as the dominant economic, political and social forces in a particular society will determine the extent and pattern of irregular land supply.

Maricato (1996) focuses on the relationship between informality, inequality and violence in Brazilian cities. Using a Marxist theoretical framework and based on secondary data analysis, informality is described as a result of the process of "exclusionary modernization" that has characterized capitalism in Brazil and the main factors contributing to the informal production of housing as: (i) low wages, (ii) the concentration of land rent by the private property rights regime, (iii) the cost of the urban regulatory regime, and (iv) the use of public investment favoring industrial accumulation and infrastructure.

Smolka (2003) focuses on the interdependence of formal and informal urban land markets in Latin America. Using secondary data analysis, the author argues that in addition to the high price of serviced land, other factors that explain the extent and

\footnotetext{
${ }^{11}$ Self-help housing refers to houses built over time by the occupant of a plot of land located either in a favela or in an irregular or clandestine subdivision (loteamento).
} 
persistence of informal land markets on the supply side are: the lack of sufficient social housing programs, inadequate public investment in infrastructure, high profitability of informal developers, and "elitist" urban regulations. On the demand side, Smolka identifies as factors that lead to housing informality: low income, lack of finance, and a strategy of capital accumulation developed by the poor to protect themselves against high inflation.

The interpretation of urban regulation varies across the literature. At times it is seen as an imported or elitist concept that clashes with local social practices (Gilbert 1990 and Smolka 2003), while in other instances it is seen as an instrument of class domination (Maricato 1996). The emphasis on the causes of informality also vary between Gilbert and Maricato; the former emphasizes local conditions, while the latter emphasizes the contradictions of capital accumulation. However, all authors seem to support a conceptual framework in which informality is an outcome of the adoption of urban regulations that leads, in turn, to the increase in housing prices.

Finally, a third group of researchers, best represented by De Soto (2000), emphasizes the technical dimension of the informal housing market, focusing on the role of the legal and planning apparatus in the development of informal housing markets. De Soto attempts to explain why capitalism has worked in the West and has failed in all developing and former communist countries. Using secondary data analysis, the author argues the legal framework is the only factor that explains the presence of the informal housing sector and the lack of development in the third world. Contrary to 
the view that informality is structural in peripheral capitalist societies and can't be completely removed, the technical approach believes that informality can disappear when the legal apparatus is reformed. It is important to note that several authors have challenged the notion that changing the legal framework and regularizing properties would end informality and increase wealth.

Although in most of the studies reviewed here, land use regulation is found to be one of the factors that could explain the presence of an informal housing market, there are very few studies that have attempted to identify and quantify more specifically how land use regulations are contributing to raise housing price and push low income families to the informal housing market. This shortcoming has been addressed by recent studies that have tried to bring an economic dimension to the study of the informal housing market.

\section{The Economic Dimension}

Some recent studies have incorporated an economic dimension to the study of the informal housing market. Abramo (2003) discusses the relationship between the poor's residential mobility and the operation of the informal housing market in slums in Rio de Janeiro, Brazil. The author argues that housing prices in slums are high in comparison with formal housing prices because the informal housing market in slums is relatively inelastic. According to Abramo, this is also the result of an informal labor market that is unable to access the formal housing market because of its informal labor status. 
Biderman (2008) studied the effect of the adoption of cost-increasing regulations in municipalities in Brazil between 1991 and 2000 and found that cities that adopted regulations had an increase in the quantity of informal housing. He concluded that there is a substitution effect between formal and informal housing. This would challenge Abramo's theory that the formal and informal housing markets don't compete and the prices of the formal housing market does not affect the size of the informal housing market.

Another author that assumes a substitution effect between formal and informal housing markets is Lall et al. (2006). The authors examine the effects of land use and zoning regulations on housing supply and slum formation across Brazilian cities between 1980 and 2000. They find very inelastic housing supply in the Brazilian formal housing market, which limits formal housing supply adjustments in response to demand increases, and therefore increases slum formation. The imputed Brazilian formal housing supply elasticity is similar to those in Malaysia and South Korea, which have been regarded to have restrictive regulatory environments.

Lall et al. (2006) also find that land use regulations that manage densities - in particular, minimum lot size regulations, have important effects in terms of housing supply and slum formation. Contrary to conventional wisdom and to the findings of Biderman (2008), their research shows that lowering minimum lot size regulations do not lead to a reduction in slum formation. They argue that if some cities offer improved access to land compared to their peers, these cities are likely to 
disproportionately attract (poor) migrants. If the induced population growth is higher than formal housing supply adjustment, informality is likely to grow. The authors note that these results should not be viewed as a failure of flexible zoning to reduce slum formation. Rather, the focus should be on identifying pre-existing distortions in the land and housing market that reduce the formal housing supply response to additional demand.

Feler and Henderson (2008) examine 447 localities in 123 urban areas in Brazil between 1980 and 2000 to understand the relationship between the provision of infrastructure, such as water and sewage access, and the growth of slums. The authors find evidence that localities limit the availability of infrastructure services in slums to reduce their growth. Although this study doesn't strictly analyze the relationship between urban regulation and the informal housing sector, it claims that urban development policies can affect the size of the informal housing sector, in this case with an exclusionary policy to limit the size of slums in their localities.

This is similar to what Lall et al. (2006) argue in their paper. According to them, in the long run, urban regulation serves as newcomer taxes for potential migrants, reducing migration and slum growth as a consequence. In their study, they argued that more flexible regulations ended up attracting more migrants and that might explain the increase in slums in municipalities that adopted less restrictive regulations. 
Brueckner and Selod (2008) propose a new theoretical model in which squatters and formal residents are part of a single market competing for land within a city. On one side, the authors propose a simplified demand function for the consumption of land by the formal market. One of the innovations of the paper is to develop a demand function for the consumption of land by squatters based on the cost of eviction, which is a function of defensive expenditures per household (bribes paid to politicians, cost of political organizing, or payments to security), the size of the squatter group, and an institutional parameter measuring the difficulty of property-rights enforcement in the economy. The model portrays squatters as "squeezing" the formal market by occupying land that could be developed for formal use, raising the price paid by formal residents. The squatter organizer, however, ensures that this squeezing is not too severe, since otherwise the formal price will rise to a level that invites eviction by landowners.

From the review of the literature on the informal housing market, it is clear that there are several areas still open to debate. Most studies assume a substitution effect between the formal and informal housing markets, although authors such as Abramo question it. Most studies either model the relationship between regulation and informality (Biderman 2008, Feler and Henderson 2008, Lall et al. 2006) or the relationship between formal housing price and informality (Brueckner and Selod 2008, Abramo 2003), but few incorporate all elements into the same model. And none of these studies take into consideration the possibility of spatial autocorrelation of formal housing price. 


\section{Chapter 3: Methodology}

\section{$\underline{\text { Research Question }}$}

This study tries to understand the relationship between housing price, land use regulation and informality by addressing three related questions: (1) Does a stricter regulatory environment increase formal housing price? (2) Does an increase in the price of formal housing lead more people to find a housing alternative in the informal sector? (3) Does an increase in the price of housing in one geographic area lead more people to find a housing solution in the informal sector in a neighboring geographic area?

Three hypotheses will be tested to answer these questions. The hypothesis underlying the first question is that holding structural, neighborhood and location characteristics of the housing unit constant with a hedonic price model, a more restrictive land use regulation increases housing price in the formal housing market.

The hypothesis underlying the second question is that informal housing is an imperfect substitute for formal housing, so that an increase in formal housing price causes the quantity demanded of informal housing to increase.

The hypothesis behind the third question is that there is a spatial interaction, so that the rise in housing price in one area will lead low income households to look for a 
housing solution in the informal market not only in that area, but also in neighboring areas. The spillover effect of housing price adopted in one geographic area on neighboring areas will be assessed and tested by incorporating spatially lagged variables of housing price in to the regression analysis. Urban regulation is treated as endogenous, therefore a model for the determinants of urban regulation is incorporated in this analysis.

\section{Empirical Model}

This study uses a simultaneous equation model with three equations. In the first equation, $P_{f}=f_{1}(S, N, L, R)$, where $P_{f}$ is formal housing price, $S$ is a measure of structural characteristics of the housing unit, $N$ is a measure of neighborhood characteristics, $L$ is a measure of location within the market, and $R$ is a measure of urban regulation.

Formal housing price $\left(P_{f}\right)$ is measured by the median assessed value of a housing unit in each neighborhood, according to municipal property tax cadastres. Structural characteristics $(S)$ are measured by the median area of houses in each neighborhood in square meters, according to municipal property tax cadastres, and by the percentage of properties that are built with permanent materials in the neighborhood according to the census. Neighborhood characteristics $(N)$ are measured by the percentage of houses with access to water, sewage, electricity and paved streets in the neighborhood according to the census. Distance from the downtown area of Curitiba in kilometers is used as a measure for location $(L)$. There are six measures of urban 
regulation $(R)$ : Minimum Plot Area (square meter), Maximum Number of Floors, Minimum Front Setback (meter), Minimum Frontage (meter), Occupation Ratio (the ratio between the projected built area and the plot area), Floor-to-Area Ratio (the ratio between the total built area and the plot area).

Regulation is treated as endogenous, by adopting a regression that has $R=f_{2}(I, D, Z)$, where $I$ is a measure of income using as a proxy the percentage of people with 15 years of education or more; $D$ is a measure of demographic characteristics measured by the size of the population; and $Z$ is a measure of political climate measured by the percentage of owner-occupied houses. Ideally, this data should be collected for the year immediately before the regulations were approved.

The third regression models the determinants of informal housing quantity with the function: $Q_{i}=f_{3}\left(P_{f}, N, L, I, D\right)$, where $Q_{i}$ is the quantity of informal houses, $P_{f}$ is formal housing price, $N$ is a measure of neighborhood characteristics, $L$ is a measure of location within the market, $I$ is income and $D$ is a measure of demographic characteristics measured by the size of the population, annual percentage change in population, number of people married and percentage of families headed by blacks and $\operatorname{pardos}^{12}$.

\footnotetext{
${ }^{12}$ The Brazilian Institute of Geography and Statistics (IBGE) defines pardos as a multiracial group with at least one of their race being black. For statistical purposes, pardos are considered blacks in government policies.
} 
The final simultaneous equations model has the following equations:

$$
\begin{aligned}
& R=\beta_{10}+\beta_{11} I+\beta_{12} D+\beta_{13} Z++\varepsilon_{1} \\
& P_{f}=\beta_{20}+\beta_{21} S+\beta_{22} N+\beta_{23} L+\alpha_{1} R+\varepsilon_{2} \\
& Q_{i}=\beta_{30}+\alpha_{2} P_{f}+\beta_{31} N+\beta_{32} L+\beta_{33} I+\beta_{34} D+\varepsilon_{3}
\end{aligned}
$$

Regulation $(R)$, Formal Housing Price $\left(P_{f}\right)$, and Quantity of Informal Housing $\left(Q_{i}\right)$ are endogenous variables. Income $(I)$, demographic characteristics $(D)$, political climate $(Z)$, structural characteristics of the housing unit $(S)$, neighborhood characteristics $(N)$, and location $(L)$ are exogenous variables; $\alpha$ is used for parameters on endogenous variables, while $\beta$ is used for parameters on exogenous variables.

The regressions are initially run separately to check if the data yields expected results and to adjust the model specification to its best functional form. After deciding on the final specification for each equation, a three-state least square regression is used to run the simultaneous equation model.

In order to test for spatial autocorrelation for the price of formal housing, Moran's I test is used. The value of the Moran's I test is similar to a correlation coefficient, varying between -1 and 1 . It measures the correlation between formal housing price and the spatial lagged variable of formal housing price. When autocorrelation is high, 
the coefficient is correspondingly high so that a high I-value indicates a high spatial correlation. A high spatial correlation means that neighborhoods with high formal housing price are surrounded by neighborhoods with high formal housing price or, inversely, neighborhoods with low formal housing price are surrounded by neighborhoods with low formal housing price. Outliers are those localities with high prices located surrounded by areas with low prices and vice-versa. Inference for Moran's I is based on a random permutation procedure, which recalculates the statistics many times to generate a reference distribution and a pseudo significance level.

In this study, Moran's I test is applied using five spatial weight matrices: one distance-based and four contiguity-based using rook contiguity spatial weight matrices of first to fourth order. As the spatial autocorrelation is detected in continuous or contiguity-based variables, spatial lagged variables for formal housing price are created and used in the third equation to correct the problem. The variables are added as explanatory variables in the equations to capture the spatial pattern.

\section{$\underline{\text { Data }}$}

The units of observation are 108 geographic zones in 13 municipalities that are part of the metropolitan area of Curitiba, Brazil. Seventy five geographic zones coincide with the 75 official neighborhoods in the city of Curitiba and the other 33 geographic zones are located in the twelve municipalities around the city of Curitiba. 


\section{Formal Housing Price Measure}

For the measure of formal housing price $\left(P_{f}\right)$, the median assessed value of residential properties for the year 2000 was used. The assessed price comes from the cadastres created by municipalities for property tax purposes. In the case of Curitiba, Campo Largo, Pinhais, Piraquara, Quatro Barras, and Sao Jose dos Pinhais, the whole cadastre of residential properties in each geographic zone was used to get the median value. In the other municipalities, a sample of 100 residential units was used to get the median value. In eight of the 108 geographic zones there were less than 100 residential properties to calculate the median value. It is important to note that it wasn't possible to separate different housing markets, therefore the median assessed value included all residential properties, from single family houses to apartments in multifamily buildings.

One anomaly of the data is that some municipalities didn't have the cadastre information for 2000. For those municipalities the assessed value of the closest year, 2001, was used. That is the case of Almirante Tamandare, Campina Grande do Sul, Fazenda Rio Grande, Mandirituba, and Piraquara.

It is also worth noting that the municipal assessed value of a residential unit doesn't necessarily correspond to the market value of properties. The assessed value is normally below market price and there are additional distortions. But there aren't many alternatives to get formal housing price in Brazil in general, and in the Curitiba region in particular. SECOVI, a private organization that represents real estate 
companies, collects data on residential properties for sale. The problem with this data is that it doesn't cover the whole study area, it reports the asking price and not the sale price, and it is based on newspaper ads, therefore properties that have ads in multiple months and/or years, could be reported several times and they might distort the median house price in a neighborhood. There is a $61 \%$ correlation between the median assessed value collected from municipal cadastres and SECOVI's median housing price in 68 units of observation. This shows that, although we would prefer data to be more convergent that this, it is positive that the correlation is above average.

\section{Urban Regulation Measure}

For the measure of urban regulation $(R)$, data was collected on the following zoning requirements as applied in the year of 1999: Minimum Plot Area (square meter), Maximum Number of Floors, Minimum Front Setback (meter), Minimum Frontage (meter), Occupation Ratio (the ratio between the projected built area and the plot area), and Floor-to-Area Ratio (the ratio between the total built area and the plot area). In each of the 108 geographic zones there was generally more than one zoning regulation, each of them with different zoning requirements. A methodology was created to determine a "median density zoning" in each geographic zone.

The methodology included the following steps. First, each municipality's zoning regulation (zoning law and map) that was effective in 1999 was collected. Second, in each geographic zone, all the zonings that were effective and their area of coverage 
were listed. For example, in Campina Grande do Sul, one of the geographic zones had five different zonings (residential type 2 zone covering $50 \%$ of the area, special control zone covering $25 \%$ of the area, rural zone covering $10 \%$ of the area, green zone covering $7.5 \%$ of the area, and industrial zone covering $7.5 \%$ of the area).

Then, each zoning where residential use was permitted, was ranked from the highest permitted density of occupation, to the lowest permitted density of occupation, using the following criteria: a) the one with the smallest minimum plot area for residential zoning was ranked with the highest density; b) when two residential zonings had the same minimum plot area, the one with the larger maximum number of floors was ranked higher; c) when (a) and (b) were the same, the one with largest Floor-to-Area Ratio was ranked higher; d) when all other factors were the same, the one with largest occupation ratio was ranked higher; e) when all other factors were the same, the one with smallest minimum frontage was ranked higher; f) when all other factors were the same, the one with smallest minimum front setback was ranked higher.

Finally, to get the median density zoning in the geographic zone, all zonings where residential use was permitted were listed, from the highest density to the lowest density, using the criteria discussed above. The zoning that was at the median point, where $50 \%$ of the territory where residential use was permitted was at those zoning parameters in terms of density or below, was the zoning selected. The requirements in terms of Minimum Plot Area, Maximum Number of Floors, Minimum Front Setback, 
Minimum Frontage, Occupation Ratio, and Floor-to-Area Ratio of the median density zoning were adopted for that geographic zone.

It is important to note that not all zonings have requirements for all the categories of interest. Therefore, not all 108 geographic zones have valid units of observation for all zoning requirements. For instance, occupation ratio has 104 units of observation, minimum font setback has 101, minimum frontage has 83 , maximum number of floors has 82, and Floor-to-Area ratio has only 39. Minimum plot area is the only regulatory variable that is observed in all 108 geographic zones.

It was mentioned before that the model of the determinants of urban regulation should ideally get data from the period immediately before the approval of the regulations. Most regulations in the study area were approved in 1980, so the census data of 1980 would provide the best source of data. Unfortunately, the census data for 1980 was not readily available, so the data for 1991 was used instead. In addition, the income measure couldn't be obtained for 1991, so the percentage of adults with 15 years of education or more was used as a proxy for income. In 2000, the correlation coefficient between median income and percentage of adults with 15 years of education or more was 0.93 .

\section{Quantity of Informal Housing Measure}

For the measure of quantity of informal houses $\left(Q_{i}\right)$, the 2000 census data on houses where the occupant owns the house but doesn't have title to the land was used. As 
discussed in Biderman (2008), there are three proxies for study of informal housing in Brazil. The first is the census data on subnormal agglomerations, defined as a group of 50 or more residences built with temporary materials (shacks), located in a settlement that presents a disorganized pattern of occupation and lacks essential public services. Squatter settlements will most likely be captured by these measures, but irregular land developments will most likely be left out.

A second proxy is a measure of houses that lack public services, such as sewage and water connection. The problem with this measure is that it leaves out a great proportion of houses that are informal but have access to public services, because of extensive neighborhood upgrading policies and programs carried out over the past 20 years in Brazil to improve housing conditions in informal neighborhoods.

We are left with the measure of houses where the occupant owns the house but not title to the land. This measure captures not only houses in squatter settlements, but it also captures houses that are built in irregular land developments, where houses are not shacks, the street pattern is organized, and there might be access to public services, but the land was developed and purchased informally. One of the problems associated with this measure is that it didn't exist in the census of the 1970s and 1980s, so it cannot be used in time series analysis. Because this is not the case of this study, this measure was chosen for the quantity of informal housing. 


\section{Other Variables}

The census provided the following data: population size in 1991 and 2000; and annual rate of population growth between 1991 and 2000; the number of adults with more than 15 years of education in 1991 and 2000; the number of married couples in 2000; the number of black and pardo (mixed black) head of households in 2000; median income per household in 2000; total number of housing units in 1991 and 2000; number of housing units with permanent structures, with access to water, sanitation, electricity and paved roads in 1991 and 2000; and number of owner occupied housing units in 1991 and 2000. Table 5 presents the descriptive statistics of the variables of interest. 
Table 5 - Descriptive Statistics

\begin{tabular}{|c|c|c|c|c|c|}
\hline & $\mathbf{N}$ & Minimum & Maximum & Mean & $\begin{array}{c}\text { Std. } \\
\text { Deviation }\end{array}$ \\
\hline Floor space $(\mathrm{m} 2)$ & 108 & 32 & 256 & 116.2958 & 51.59986 \\
\hline Median Formal Housing Price $2000(\mathrm{R} \$)$ & 108 & 2640 & 120600 & 33990.1 & 26767.49 \\
\hline Median Housing Property Tax $2000(\mathrm{R} \$)$ & 108 & 15.99 & 762 & 145.8325 & 132.3974 \\
\hline Minimum Plot Area (m2) & 108 & 330 & 20000 & 3562.87 & 6142.691 \\
\hline Maximum Number of Floors & 82 & 1 & 6 & 2.512195 & 1.298089 \\
\hline Minimum Front Setback (m) & 101 & 5 & 20 & 7.623762 & 4.449385 \\
\hline Minimum Frontage (m) & 83 & 11 & 50 & 16.3494 & 9.45778 \\
\hline Occupation Ratio & 104 & .05 & 1 & .4200962 & .198007 \\
\hline Floor-to-Area Ratio (FAR) & 39 & 0.1 & 5 & 1.090769 & .9500205 \\
\hline Size of the Population in $1991(1,000)$ & 108 & .188 & 114.474 & 17.37731 & 21.24102 \\
\hline Size of the Population in $2000(1,000)$ & 108 & .236 & 167.583 & 23.29299 & 29.85801 \\
\hline Annual Percentage Change in Population 1991-2000 & 108 & -2.291009 & 22.9655 & 3.572775 & 4.739449 \\
\hline Housing Units 2000 & 108 & 62 & 46632 & 6796.407 & 8308.842 \\
\hline Percentage of Houses w/ Permanent Structure 2000 & 108 & 45.06509 & 100 & 97.30379 & 6.045175 \\
\hline Percentage of Houses w/ Sewage Connection 2000 & 108 & 0 & 100 & 58.18325 & 32.95237 \\
\hline Percentage of Houses w/ Water Connection 2000 & 108 & 20.25745 & 100 & 89.92819 & 14.52602 \\
\hline Percentage of Houses w/ Electricity 2000 & 108 & 44.8284 & 100 & 97.00058 & 6.096412 \\
\hline Percentage of Houses w/ Paved Streets 2000 & 108 & .3707018 & 98.94434 & 65.87176 & 32.24868 \\
\hline Subnormal Housing 2000 & 108 & 0 & 8449 & 412.1204 & 1215.855 \\
\hline Informal Housing 2000 & 108 & 0 & 5272 & 490.5 & 823.7264 \\
\hline Household Median Income $2000(\mathrm{R} \$)$ & 108 & 300 & 5000 & 1170.093 & 892.8065 \\
\hline Number of People Married 2000 & 108 & 88 & 55177 & 7961.111 & 10036.29 \\
\hline Percentage of Households headed by blacks/pardos 2000 & 108 & 0 & 38.32921 & 15.26654 & 8.99392 \\
\hline Percentage of Population $\leq 25$ yrs old 2000 & 108 & 30.48162 & 58.23051 & 45.49307 & 7.29431 \\
\hline Percentage of Population $>25 \leq 35$ yrs old 2000 & 108 & 8.898305 & 24.78834 & 17.3212 & 2.263549 \\
\hline Percentage of Population $>35 \leq 45$ yrs old 2000 & 108 & 9.736594 & 19.78824 & 14.79949 & 1.652016 \\
\hline Percentage of Population $>45 \leq 55$ yrs old 2000 & 108 & 4.867341 & 16.01698 & 10.35258 & 2.479167 \\
\hline Percentage of adults w/ 15 years of education or more (1991) & 108 & 0 & 39.92 & 9.725278 & 11.41994 \\
\hline Percentage of adults w/ 15 years of education or more (2000) & 108 & 0 & 47.79902 & 12.94266 & 14.05942 \\
\hline Percentage of owner- occupied houses (1991) & 108 & 0 & 83.17 & 60.98852 & 13.11989 \\
\hline Percentage of owner- occupied houses (2000) & 108 & 37.5858 & 95.49746 & 75.43442 & 8.02515 \\
\hline Geographic Zone Area $(000,000 \mathrm{~m} 2)$ & 108 & .88 & 123.56 & 17.31491 & 25.57012 \\
\hline Distance from Curitiba's Downtown Area (km) & 108 & 0 & 38.215 & 10.65847 & 7.991698 \\
\hline
\end{tabular}




\section{Chapter 4: Spatial Data Analysis}

Before moving into the results section, a spatial analysis of the main variables of interest is presented in two parts: the first presents an analysis of the data using quantile maps and the second presents the spatial autocorrelation analysis.

Figure 10 shows the study area. As explained before, there are 108 geographic zones in 13 municipalities that are part of the metropolitan area of Curitiba. Seventy five geographic zones coincide with the 75 official neighborhoods in the city of Curitiba and the other 33 geographic zones are located in the twelve municipalities around Curitiba.

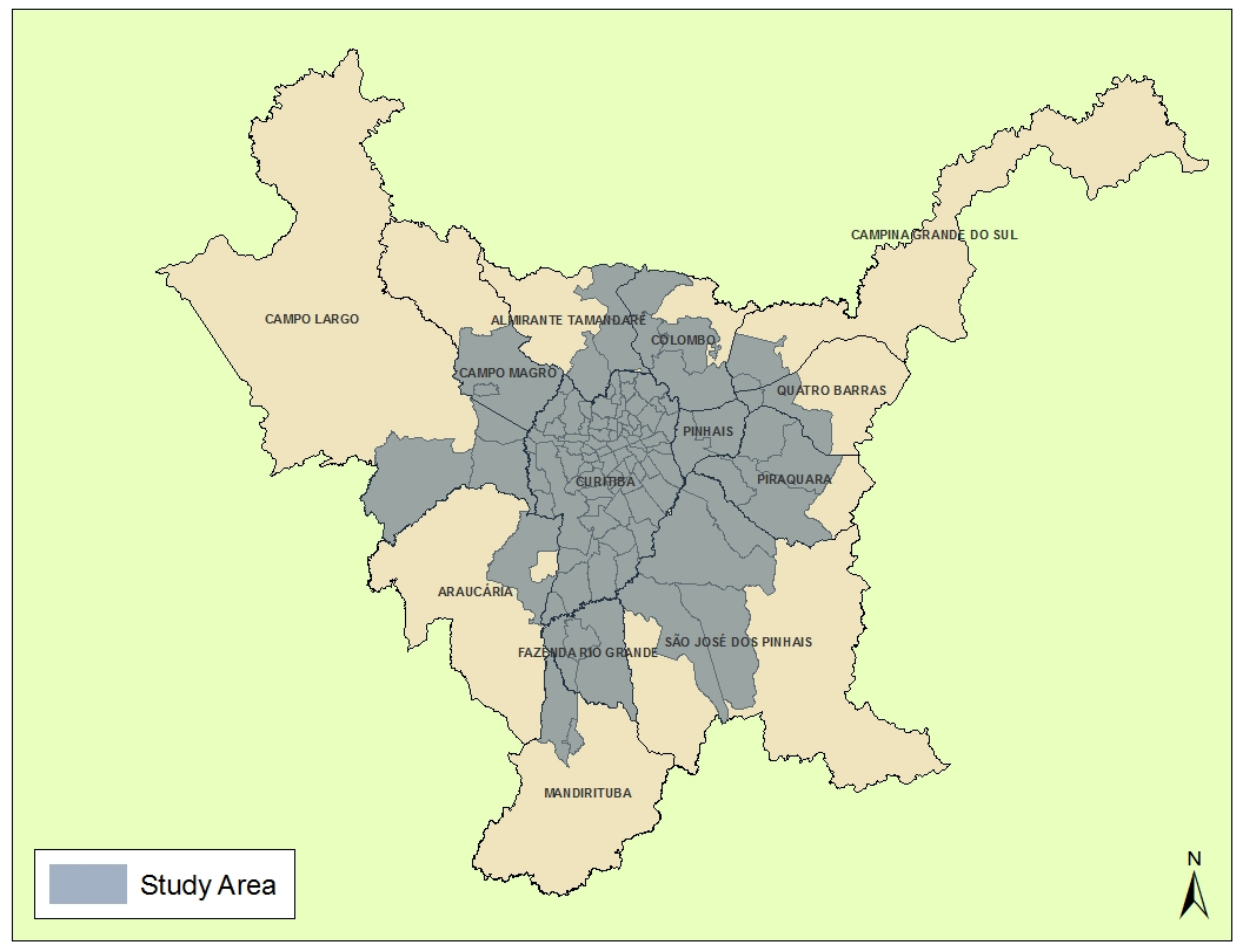

Figure 10 - Study Area 


\section{Quantile maps}

Figure 11 shows a classification of the zones by quantile in terms of the median house price. The map shows that one third of the zones with the highest median housing price are predominately located in the center, within a $5 \mathrm{~km}$ radius around the downtown area of Curitiba. One third of the zones with the lowest median housing price are located in the periphery. The other third are located predominantly in the middle, in a ring that stretches 5 to $15 \mathrm{~km}$ from the downtown area of Curitiba.

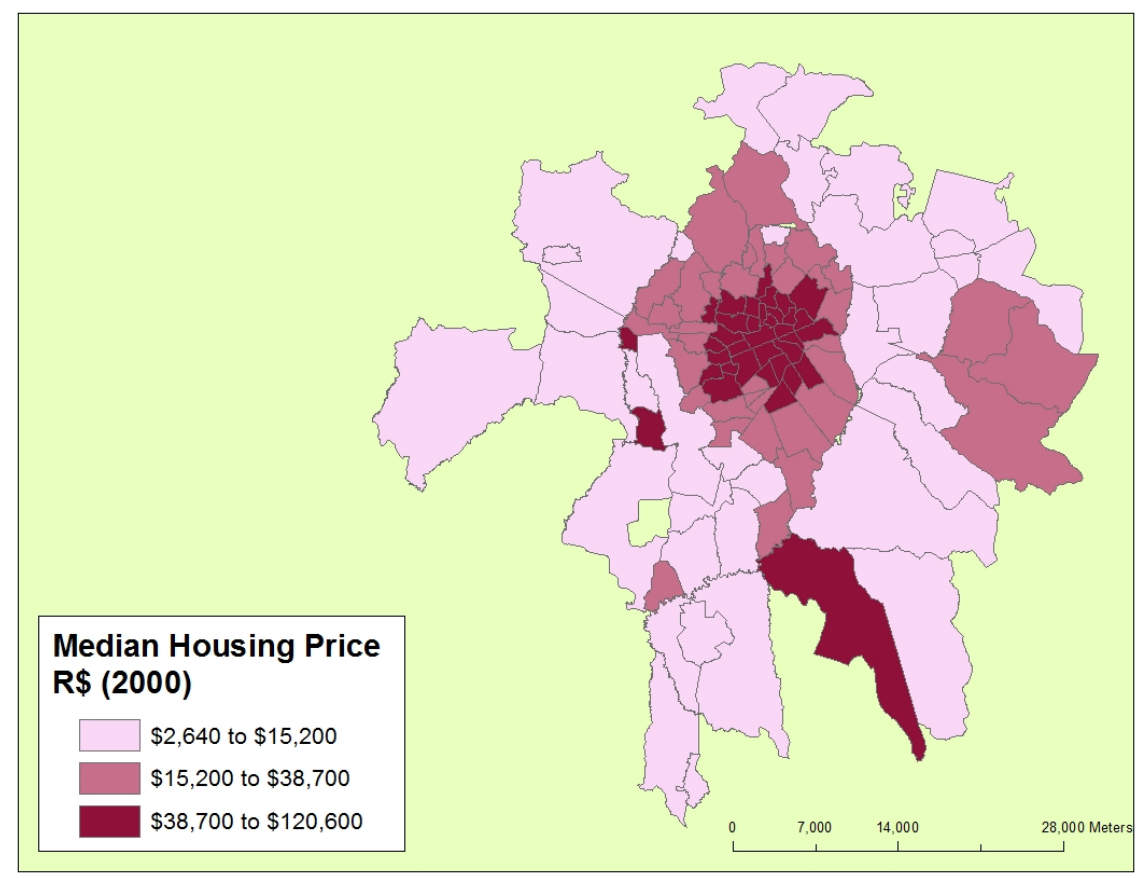

Figure 11 - Quantile Map with Median Formal Housing Price R\$ (2000)

Figure 12 shows a classification of the zones by quantile in terms of the median household income. This map confirms the pattern of Brazilian urban development. The map shows that one third of the zones with the highest median income are predominately located in the center, while one third of the zones with the lowest median income are located in the outskirts of the urban area. 


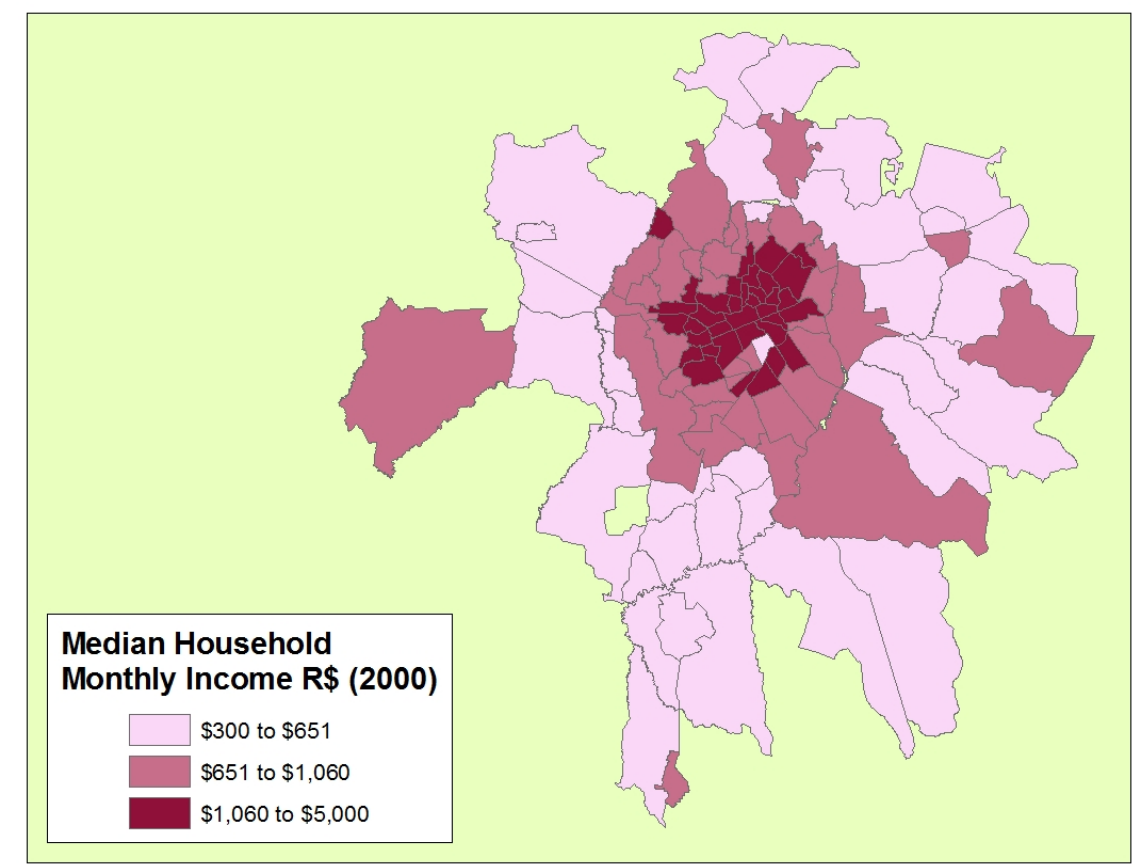

Figure 12 - Quantile Map with Median Household Monthly Income R\$ (2000)

Figure 13 shows a classification of the zones by quantiles in terms of the percentage of informal houses. For the most part, informal houses have been kept out or at low levels in the rich zones close to the downtown area. But in the rest of the city, informality doesn't have the same clear pattern that characterizes the spatial distribution of income and wealth. 


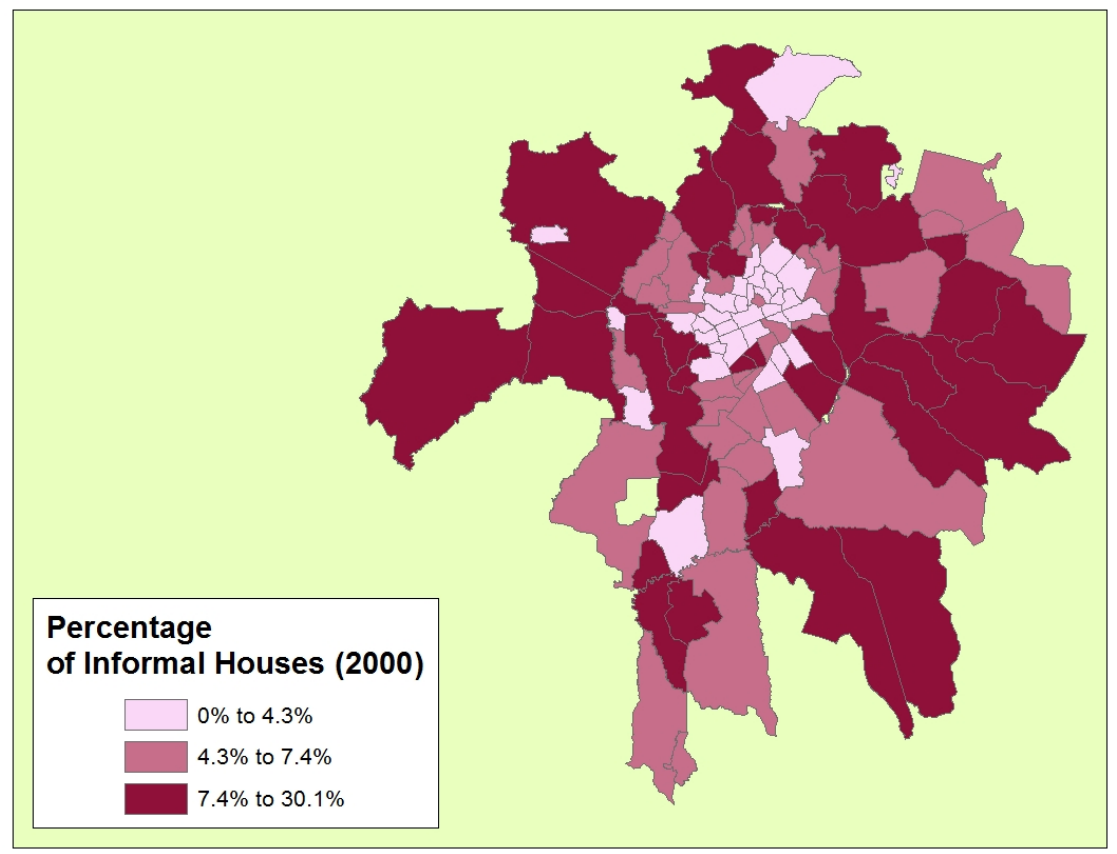

Figure 13 - Quantile Map with Percentage of Informal Housing (2000)

Figure 14 shows a classification of the zones by the percentage of houses with water connection. It is clear from the map that access to water has not been limited to the rich and wealthy areas and the majority of the urban area of Curitiba enjoys a level of connection above $88 \%$. This is consistent with the trend seen in most urban areas in Brazil in past 20 to 30 years. While in the 1970 s the periphery was characterized by the lack of all public services, in the late 1990s living conditions in these areas improved significantly because of massive investments in infrastructure from municipal and state utility companies. Although a map showing the coverage of electricity is not included in this section, its coverage is even better than that of water services, with all zones having between $97 \%$ and $100 \%$ of houses with access to electricity. 


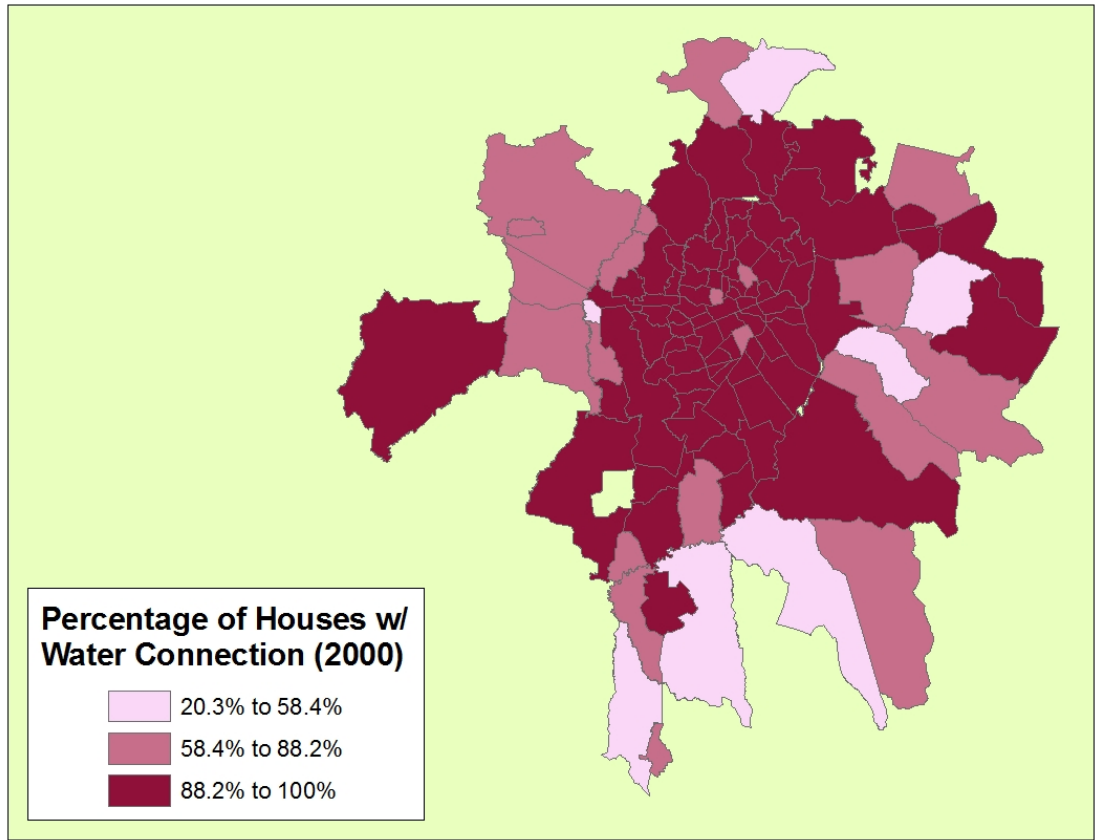

Figure 14 - Quantile Map with Percentage of Houses w/ Water Connection (2000)

Figure 15 shows a classification of the zones by the percentage of houses with sewage connection. The map shows that the percentage of coverage of sewage connection is much smaller than that of water and electricity and the extension of sewer connections is generally restricted to the wealthier parts of the city. 


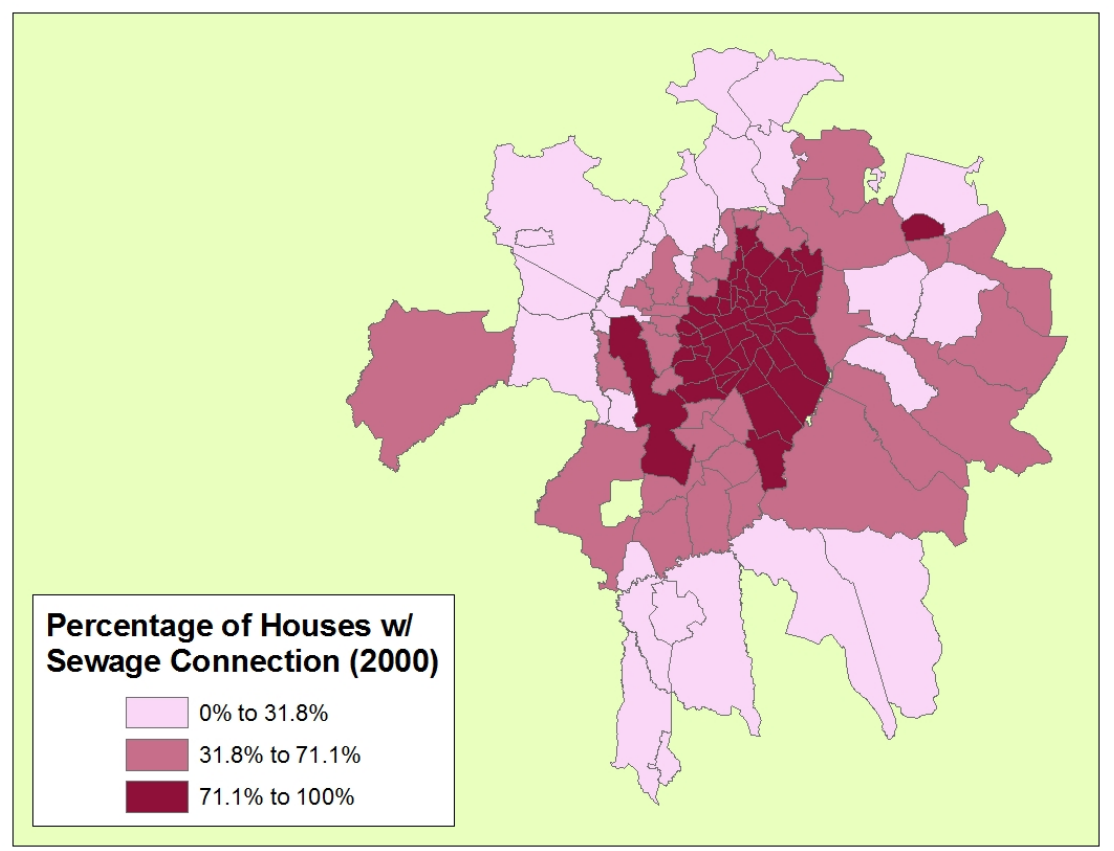

Figure 15 - Quantile Map with Percentage of Houses w/ Sewage Connection (2000)

Figure 16 to Figure 21 show a spatial classification of the median value of the six regulatory variables of interest in this study. The darker colors show the areas where a denser pattern of occupation is allowed; with this color scheme accorded to the each of the regulatory variables. In general, the regulatory variables are consistent with a higher density of occupation in centrally located areas. However, only some of them have a gradient of density that gradually decreases as the zone is further away from the center, such as Minimum Plot Area and Occupation Ratio.

For some regulatory variables, some parameters dominate. For instance, for Maximum Number of Floors, 2 is the predominant parameter applied in 68 zones out of 82 zones; for Minimum Front Setback, 5 meters is the predominant parameter applied in 72 zones out of 101; and for Minimum Front Setback, 12 meters is the predominant parameter applied in 46 zones out of 83 . For FAR regulation, the 
downtown area of Curitiba is close to an outlier, being the only zone that has a FAR of 5 . In all other zones, FAR varies between 0.1 and 2 .

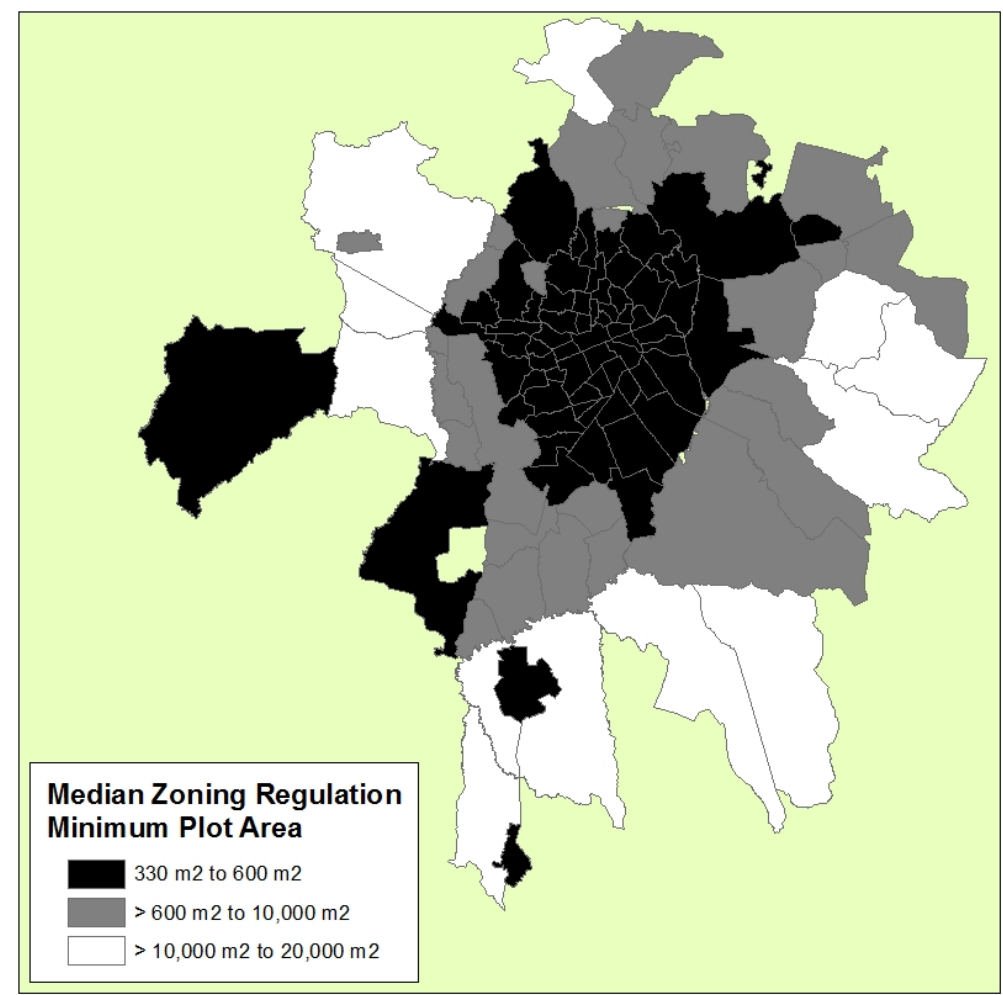

Figure 16 - Quantile Map of Median Zoning Regulation - Minimum Plot Area 


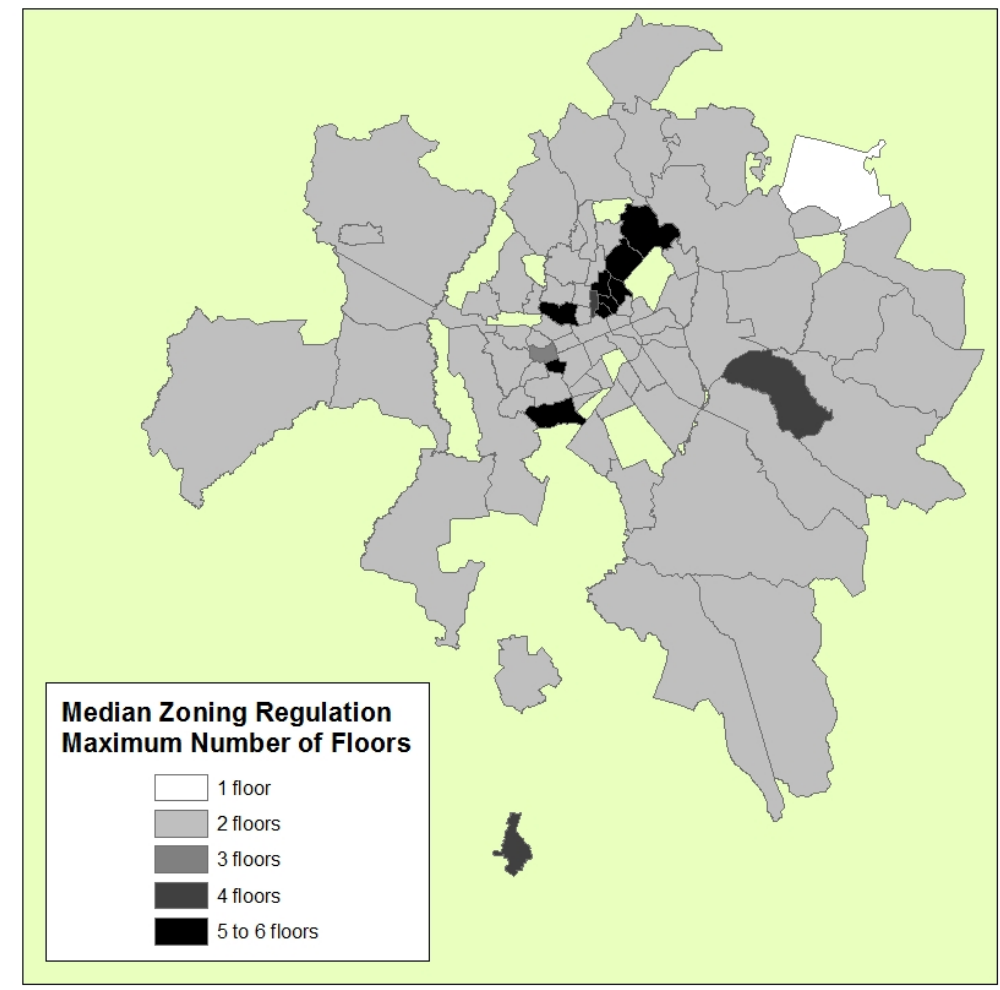

Figure 17 - Quantile Map of Median Zoning Regulation - Maximum Number of Floors

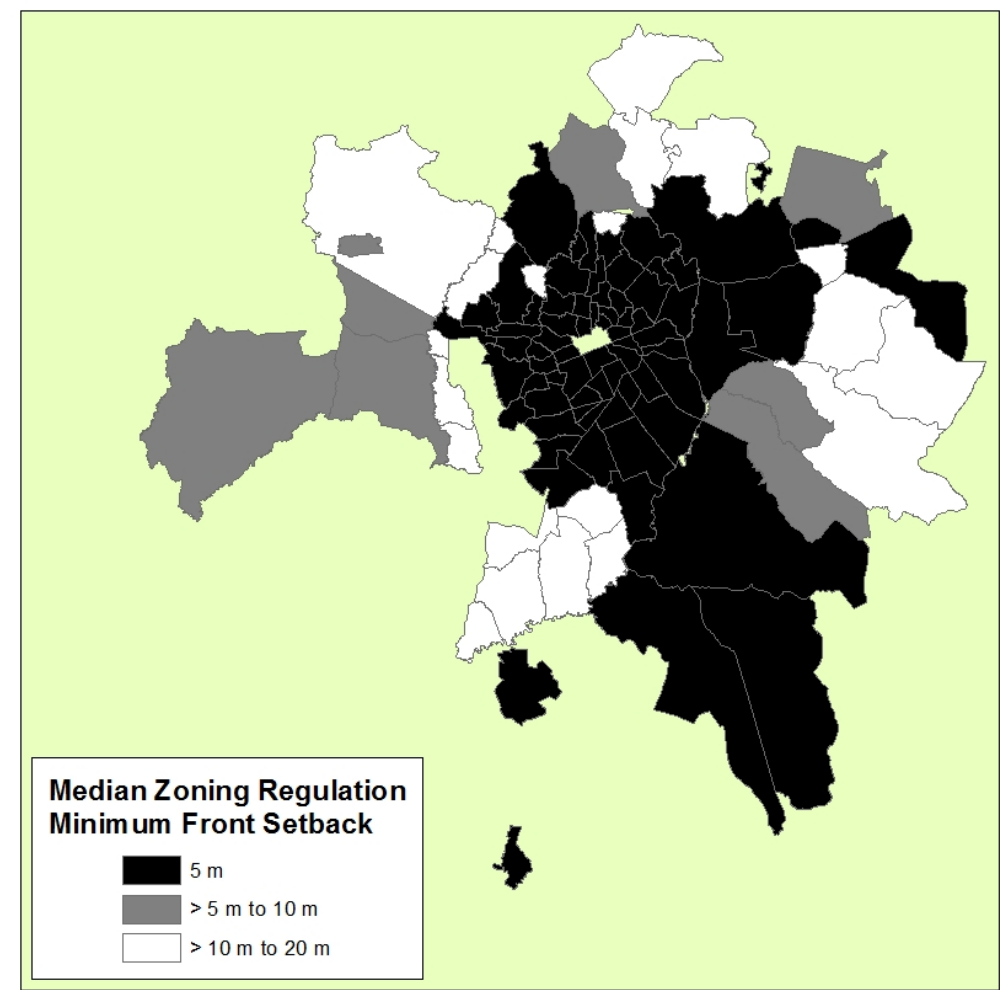

Figure 18 - Quantile Map of Median Zoning Regulation - Minimum Front Setback 


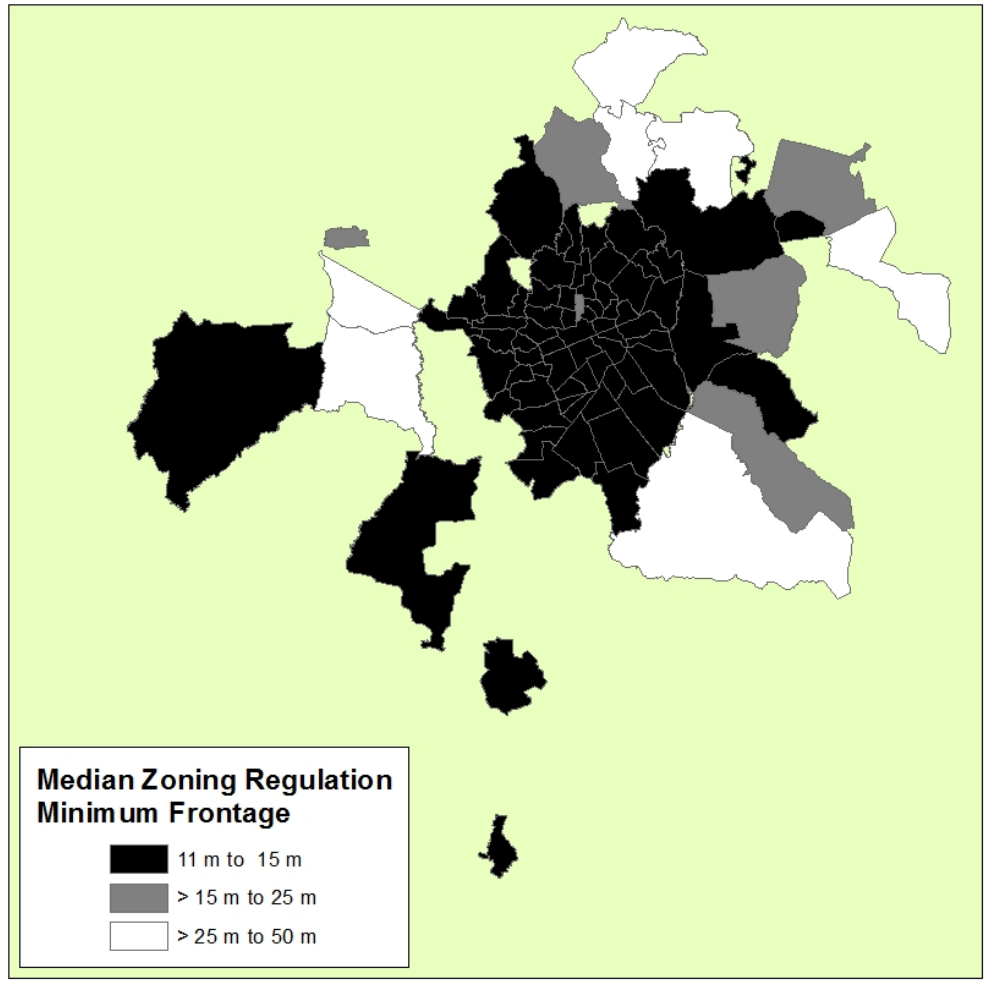

Figure 19 - Quantile Map of Median Zoning Regulation - Minimum Frontage

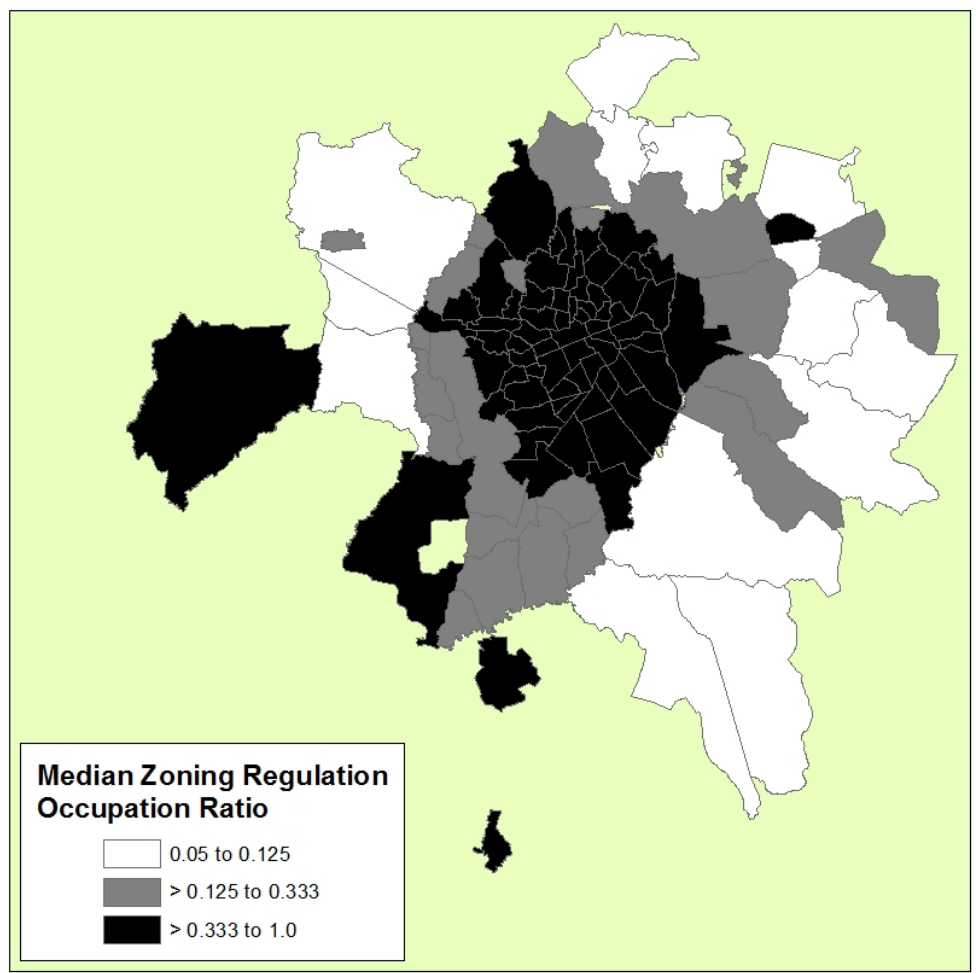

Figure 20 - Quantile Map of Median Zoning Regulation - Occupation Ratio 


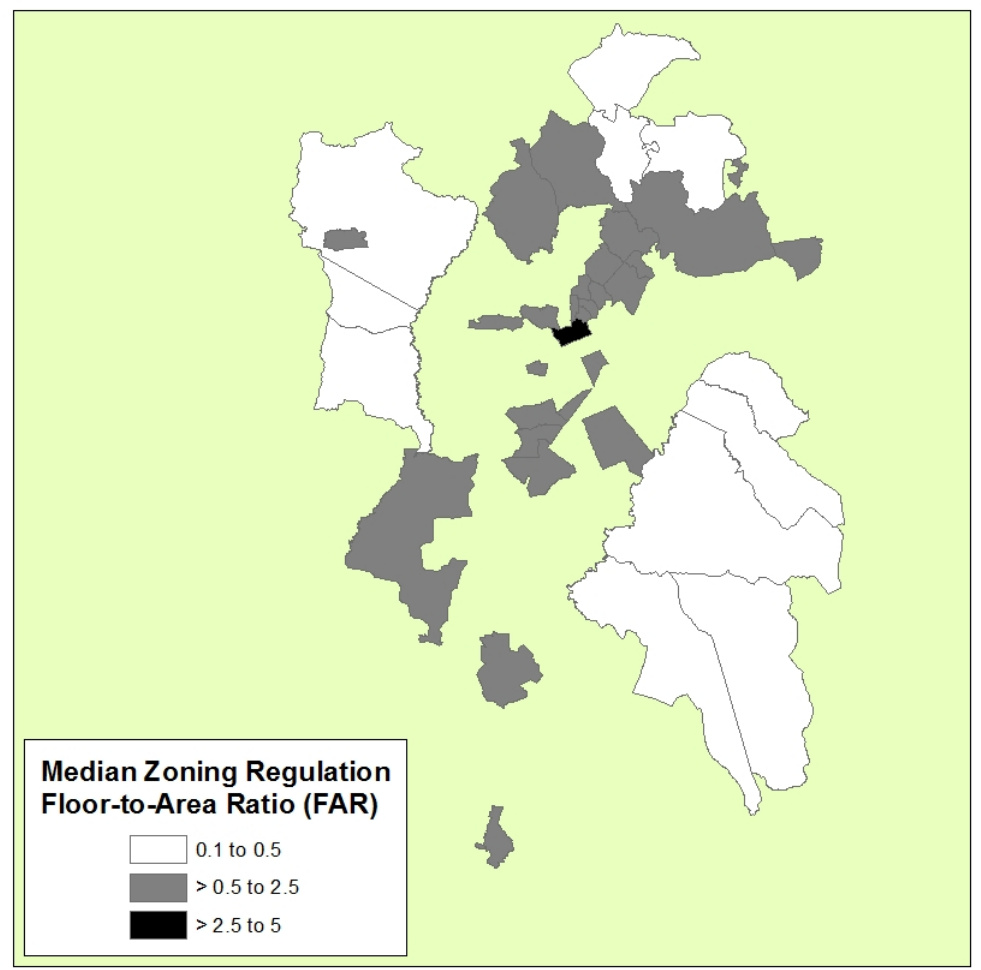

Figure 21 - Quantile Map of Median Zoning Regulation - Floor-to-Area Ratio

\section{$\underline{\text { Spatial Autocorrelation }}$}

In this section, the possibility of spatial correlation for the housing price variables are assessed using Moran's I test (Anselin et al. 2006). First, contiguity-based and distance-based spatial weights are constructed. In a contiguity-based spatial weight the neighbor is based on sharing common boundaries. The polygon shape file obtained from the World Bank and Curitiba's Research and Urban Planning Institute (IPPUC for its Brazilian acronym) is unfit for the construction of a contiguity-based spatial weight because the boundaries have several imperfections. For that reason, a Thiessen polygon shape file is created using a point shape file that uses the original polygon centroids. Below, the original shape file, the Thiessen polygon shape file 
used for the construction of distance-based spatial weights, and the point shape file used for the construction of contiguity-based spatial weights are shown below.

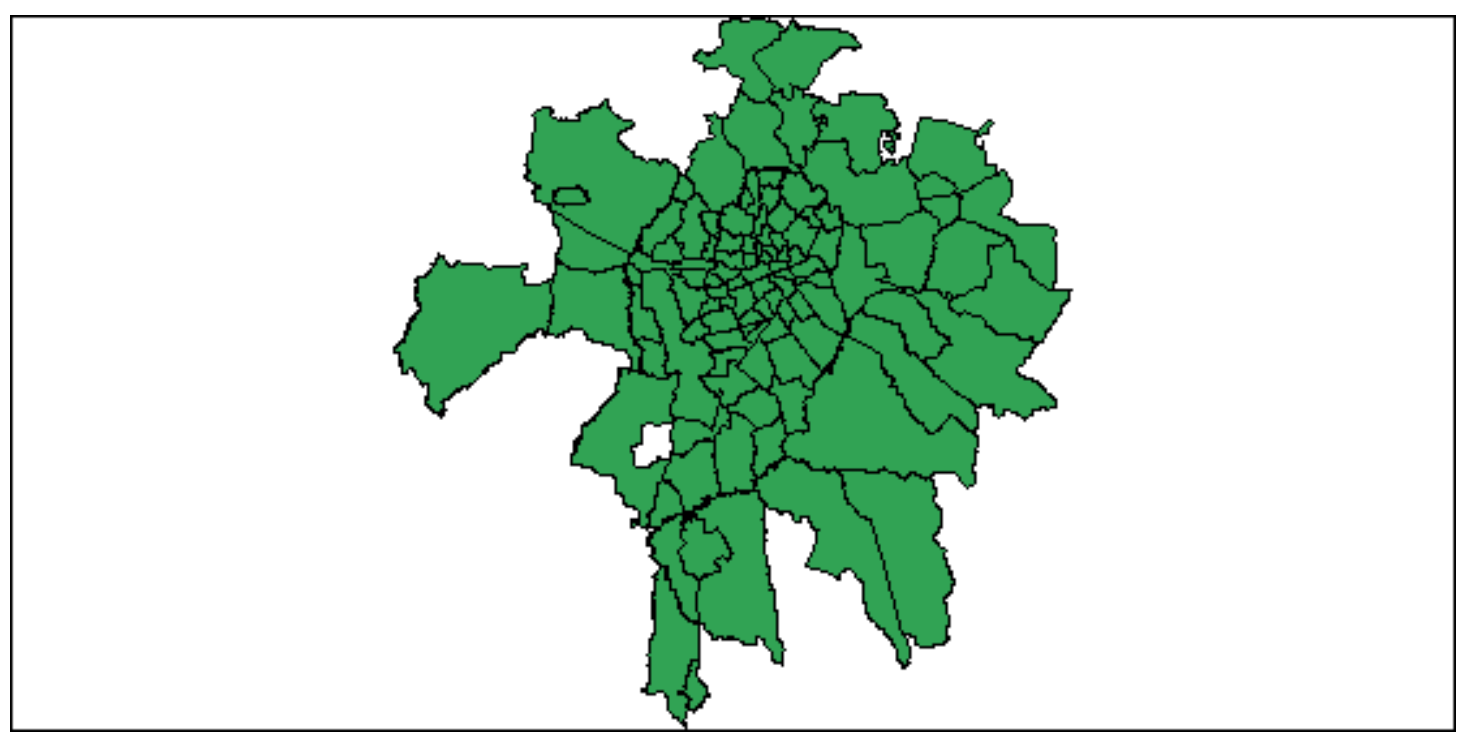

Figure 22 - Map of Study Area with Original Polygon Shape

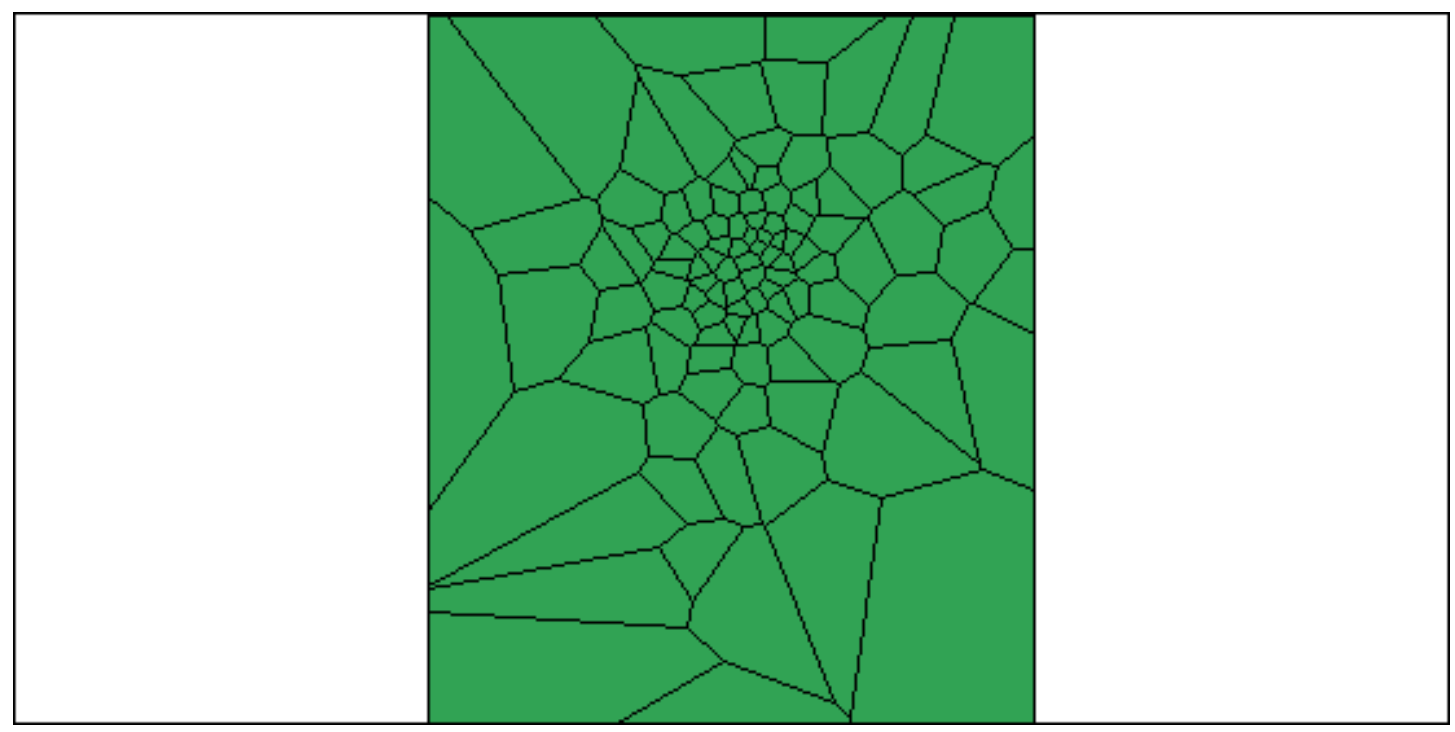

Figure 23 - Map of Study Area with Thiessen Polygon Shape 


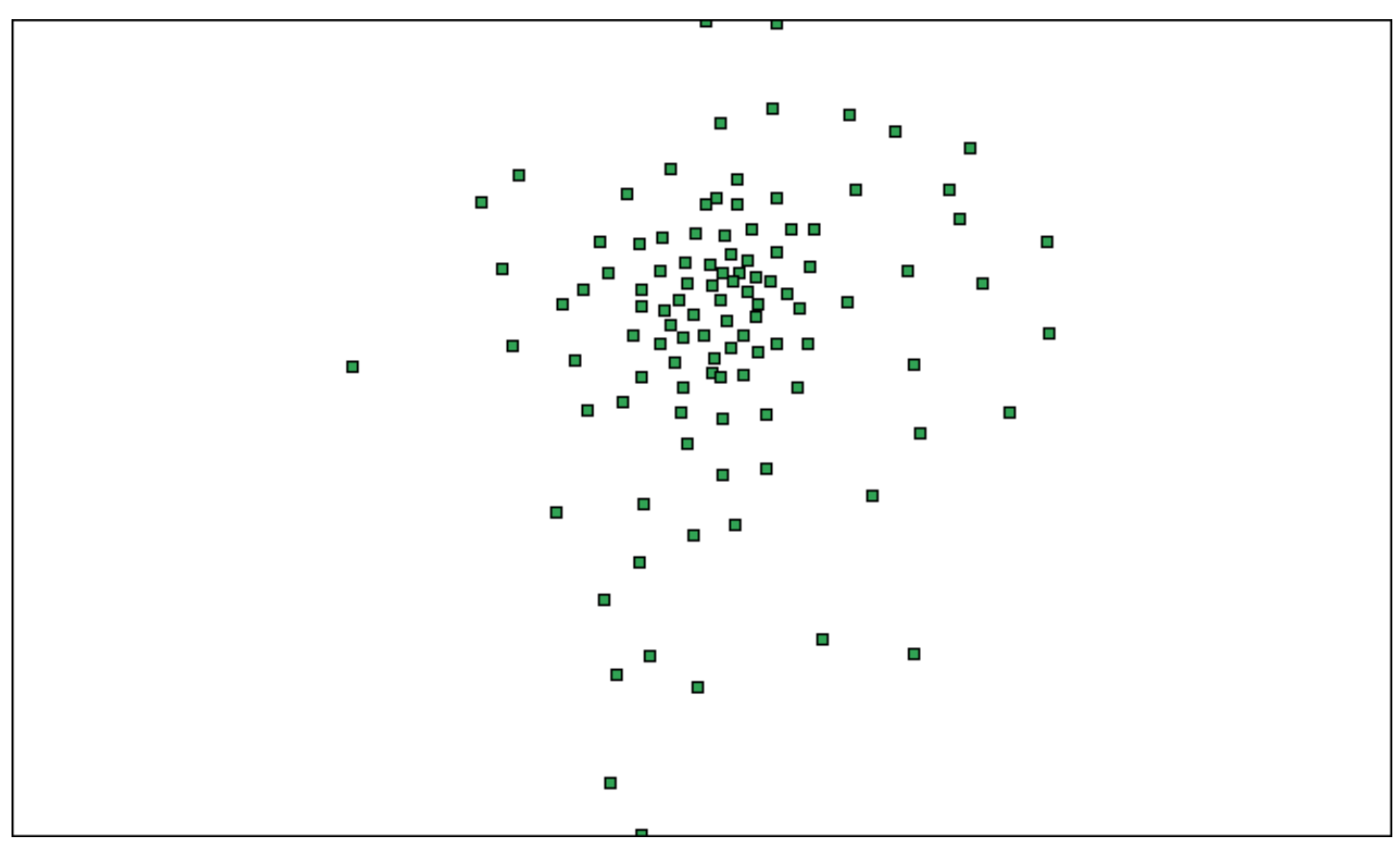

Figure 24 - Map of Study Area with Point Shape (Centroids)

There are two common definitions of contiguity for the construction of spatial weights: rook contiguity and queen contiguity. Rook contiguity only considers neighbors' polygons that share a segment boundary, while queen contiguity also includes neighbors that share a point boundary. Because Thiessen polygons don't have point boundaries, it is indifferent which contiguity is adopted. Spatial weights can also be constructed using different orders of contiguity, if the value of a unit is affected differently by the immediately contiguous units and by the second order (or higher order) contiguous units. In this study, four contiguity-based spatial weighs are created: first, second, third and fourth order rook contiguity weights. A distance-based weight is also constructed using the inverse distance between centroids of polygons.

The spatial weights are used to create five spatially lagged variables for the formal price of housing: Price_WR1 (using the first order rook contiguity weight), Price_WR2 (using the second order rook contiguity weight), Price_WR3 (using the 
third order rook contiguity weight), Price_WR4 (using the forth order rook contiguity weight), and Price_WD (using the distance-based weight). A spatial lag of a specified variable is computed by taking the weighted average of neighbor polygons. For example: zone 117 has three first order neighbors with formal housing prices of $\$ 28,400, \$ 4,705$, and $\$ 10,165$, so it has a spatial lag of $\$ 14,423.33$; that is $[(\$ 28,400$ $+\$ 4705+\$ 10,165) / 3]$. A second order contiguity weight will take the next order of neighbors and the average value of housing price of those neighbors will give us the second order spatial lag variable for formal housing price. The same method is used to get the spatial lag variables using third and forth order contiguity weights.

Moran's I is used to assess the spatial autocorrelation between the spatially lagged formal housing price variable and the original formal housing price variable. As explained before, the Moran's I can vary from 1 to -1 , just as a correlation coefficient does. A high positive or negative correlation coefficient means that there is a high spatial correlation between the variable and the spatial lag, or in other words, that neighborhoods with high housing prices are surrounded by neighborhoods with high housing prices and/or neighborhoods with low housing prices are surrounded by neighborhoods with low housing prices. Inference for Moran's I is based on a random permutation procedure, which recalculates the statistics many times to generate a reference distribution and a pseudo significance level.

Moran's I is positive and equal to 0.6402 for immediate neighbors, decreasing to 0.4513 for second order neighbors, to 0.2585 for third order neighbors, and to -0.0230 
for fourth order neighbors. The spatially lagged price variable based on distance has a Moran's I of 0.2572 . Using a random permutation procedure we find that all variables are all statistically significant except for Price_WR4.

Table 6 - Moran's I Test for Formal Housing Price Variable

\begin{tabular}{lccc}
\hline & Moran's I & Permutation & p-value \\
\hline Spatial Correlation Price_WR1 x Price & 0.6402 & 999 & 0.0010 \\
Spatial Correlation Price_WR2 x Price & 0.4513 & 999 & 0.0010 \\
Spatial Correlation Price_WR3 x Price & 0.2585 & 999 & 0.0010 \\
Spatial Correlation Price_WR4 x Price & -0.0230 & 999 & 0.3260 \\
Spatial Correlation Price_WD x Price & 0.2572 & 999 & 0.0010 \\
\hline Table 6 presents the Moran's I test for each spatially lagged variable of formal housing price. & \\
\hline
\end{tabular}

These results suggest that there is clustering in the formal housing price variable with neighbors that are close by. To further investigate this, a LISA (Local Indicators of Spatial Autocorrelation) cluster map is used for Formal Housing Price, using the first order rook weight, 999 permutations and significance level of $p=0.05$ (see Figure 25). The zones in dark red are those that have a high-high significant spatial correlation (high housing price zones surrounded by high housing price zones). The zones in dark blue have low-low significant spatial autocorrelation (low housing price zones surrounded by low housing price zones). The zones in light red are outliers and have significant high-low spatial autocorrelation (a zone with high housing price surrounded by zones with low housing price). Zones in white have no significant spatial correlation. 


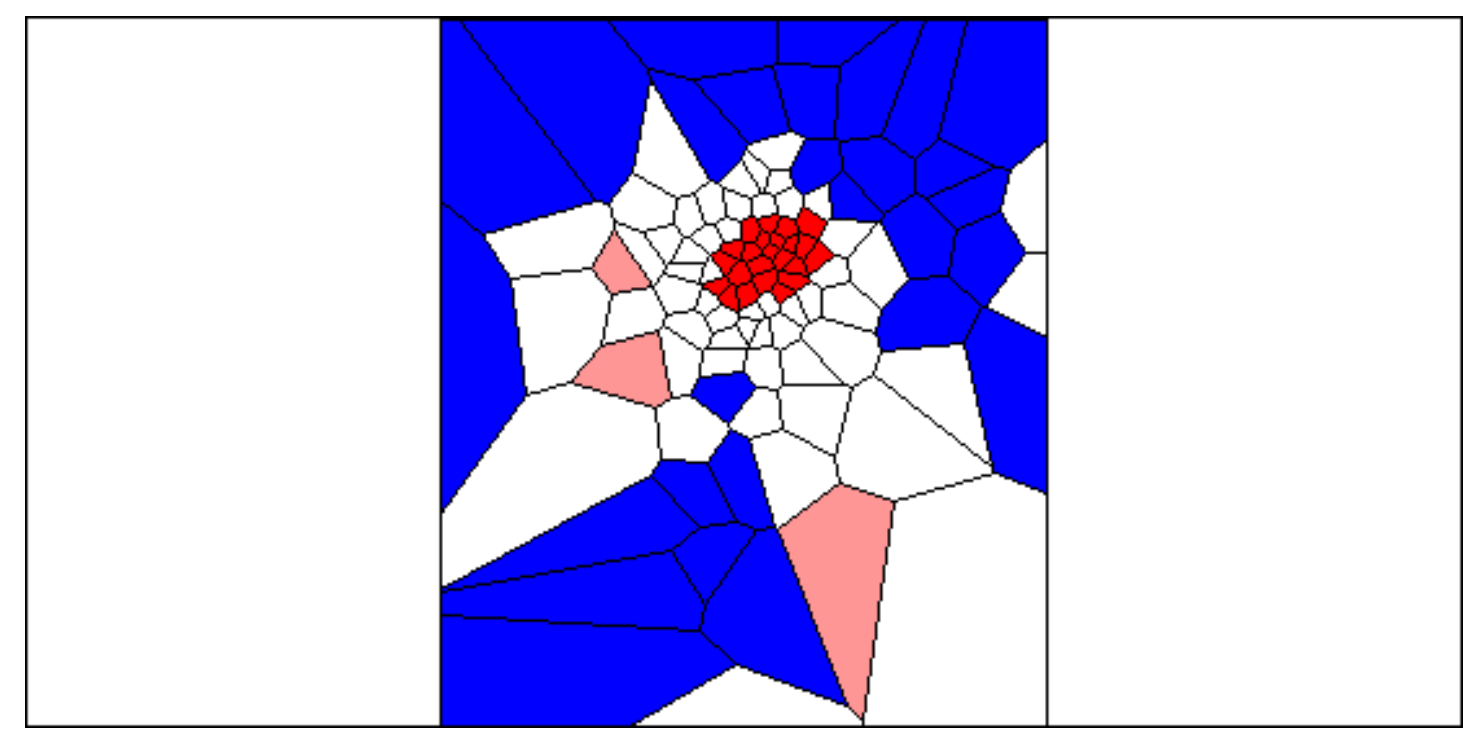

Figure 25 - LISA Cluster Map of Formal Housing Price Variable

Using First Order Rook Weight

999 permutations, significance level $p=0.05$

The cluster map shows that there is clustering of high formal housing prices at the center and clustering of low formal housing prices in the periphery with four outliers (zones with high formal housing price surrounded by neighbors with low formal housing price) in between. This reinforces the spatial data analysis that was already carried out before, with the quantile maps. It also suggests that when the spatially lagged price variable is introduced into the equation that explains the determinants of the quantity of informal housing, we would expect that more distant neighbors (Price_WR2, Price_WR3, and Price_WR4) are more likely to have a positive and significant effect on the quantity of informal housing. With that general hypothesis in mind, the analysis turns to the regression analysis. 


\section{Chapter 5: Results}

The results are reported in three parts: (a) the individual least-squares regressions for each of the three equations included in the model proposed by this study; (b) the three-stage least-squares regression; and (c) a comparison of single least-squares regression and three-stage least-squares regression to check if regulation and formal housing price are indeed endogenous variables.

\section{Single Least-Squares Regressions}

\section{Formal Housing Price Model}

The first single least square regression is a hedonic price model that measures how the different housing attributes affect formal housing price. The model uses $P_{f}=f_{1}(S$, $N, L, R)$, where $P_{f}$ is formal housing price, $S$ is a measure of structural characteristics of the housing unit, $N$ is a measure of neighborhood characteristics, $L$ is a measure of location within the market, and $R$ is a measure of urban regulation. Formal housing price $\left(P_{f}\right)$ is measured by the median assessed value of a housing unit in each neighborhood, according to municipal property tax cadastres.

After running a linear model of formal housing price and identifying a curvilinear relationship between the residuals and the fitted values, a semi-log model is used to

correct for this. Table 7 presents the results of the single model of formal housing 
price without including the regulatory variables. The model explains $78 \%$ of changes in price. Several variables are statistically significant at the $95 \%$ level, namely floor space, percentage of houses with permanent structure, percentage of houses with water connection, percentage of houses with electricity, and distance from Curitiba's downtown area.

Table 7 - Formal Housing Price Model

\begin{tabular}{lccrc}
\hline Dependent variable & Coefficient & $\begin{array}{c}\text { Standard } \\
\text { Error }\end{array}$ & $\boldsymbol{t}$-Statistic & Prob. $>|\mathbf{t}|$ \\
\hline Floor space (m2) & .0087856 & .0014182 & 6.19 & 0.000 \\
Per. of Houses w/ Permanent Structure & -.1628301 & .0783899 & -2.08 & 0.040 \\
Per. of Houses w/ Sewage Connection & .0029373 & .0023864 & 1.23 & 0.221 \\
Per. of Houses w/ Water Connection & -.0128438 & .0048736 & -2.64 & 0.010 \\
Per. of Houses w/ Electricity & .1643821 & 0.0786535 & 2.09 & 0.039 \\
Per. of Houses on Paved Streets & .0018941 & .0029602 & 0.64 & 0.524 \\
Distance from downtown area (km) & -.0341754 & .0112786 & -3.03 & 0.003 \\
Constant & 10.1832 & .7698636 & 13.23 & 0.000 \\
\hline Table 7 presents the regression on natural logarithm of formal housing price, measured by the median assessed \\
price of residential units used by municipalities for property tax purposes. Number of observations = 108 and \\
$\mathrm{R}^{2}=0.7808$
\end{tabular}

All variables have expected signs except for the percentage of houses with permanent structure and with water connection. There is a possibility that high correlation among variables might be affecting their coefficient. Permanent structure is highly correlated with electricity (0.99) and connection to water has a high correlation coefficient with paved streets (0.63).

Percentage of sewage connection and percentage of paved streets are not significant at any level, but there is a possibility that these variables might be affected by high correlation with other variables. Sewage connection is correlated with floor space (0.64), with houses on paved streets $(0.77)$, and with distance from the downtown 
area (-0.72). Paved streets is correlated with floor space (-0.66), sewage connection (0.77), water connection (0.63), and distance from the downtown area (-0.82).

\section{Urban Regulation Model}

Table 8 presents the results of the political model on the determinants of urban regulation. A single least square regression for each of the six regulatory variables collected in this study is run separately. As noted before, data for 1980 was not available for this research, so data for 1991 is used instead.

Table 8 - Urban Regulation Model

\begin{tabular}{lccrrrr}
\hline & $\begin{array}{c}\text { Min Plot } \\
\text { Area }\left(\mathbf{m}^{2}\right)\end{array}$ & $\begin{array}{c}\text { Max Num } \\
\text { Floors }\end{array}$ & $\begin{array}{c}\text { Min Front } \\
\text { Setback } \\
(\mathbf{m})\end{array}$ & $\begin{array}{c}\text { Min } \\
\text { Frontage } \\
(\mathbf{m})\end{array}$ & $\begin{array}{c}\text { Occupation } \\
\text { Ratio }\end{array}$ & $\begin{array}{c}\text { Floor-to- } \\
\text { Area Ratio }\end{array}$ \\
\hline Per. adults $\geq 15$ yrs & -223.4458 & .0366568 & -.1805736 & -.236503 & .0096476 & .0542588 \\
of educ. 1991 & $(47.86157)$ & $(.0116276)$ & $(.0344986)$ & $(.0886127)$ & $(.0014564)$ & $(.0085636)$ \\
Size of population & -76.11268 & -.0012274 & -.0697854 & -.0511663 & .0020517 & .0057808 \\
in 1991 (1,000) & $(25.69132)$ & $(.0064268)$ & $(.0204543)$ & $(.0521473)$ & $(.0007797)$ & $(.0046972)$ \\
Per. owner & 29.07814 & .0078691 & -.0104602 & .0776651 & -.0005685 & -.0251985 \\
occupied house 91 & $(41.96922)$ & $(.0101846)$ & $(.0299132)$ & $(.0796398)$ & $(.0012675)$ & $(.0135324)$ \\
Constant & 5285.143 & 1.621966 & 11.22438 & 15.44212 & .320643 & 2.067878 \\
& $(2544.444)$ & $(.6196109)$ & $(1.794326)$ & $(4.988589)$ & $(.0762075)$ & $(.8996261)$ \\
\hline $\mathrm{N}$ & 108 & 82 & 101 & 83 & 104 & 39 \\
$\mathrm{R}^{2}$ & 0.21 & 0.14 & 0.29 & 0.09 & 0.32 & 0.57 \\
\hline
\end{tabular}

In each cell, coefficients are shown on the top and standard errors are shown in parenthesis at the bottom. Coefficients highlighted in dark green are significant at the $99 \%$ level, coefficients highlighted in light green are significant at the $95 \%$ level, and coefficients highlighted in yellow are significant at the $90 \%$ level.

The model shows that in all regressions but one, the percentage of owner-occupied houses in 1991 is not significant. The percentage of adults with 15 years of education or more in 1991 is significant at the $99 \%$ level in all regressions and the size of the population is significant in three out of six regressions. 
The signs indicate an increase or a decrease in the density of occupation for each of the urban regulation variables. An increase in the minimum plot area would raise the minimum plot size, say from $250 \mathrm{~m} 2$ to $1,000 \mathrm{~m} 2$, and that would decrease the density of occupation, so a coefficient with a positive sign is decreasing density and a coefficient with a negative sign is increasing density. The maximum number of floors is the opposite. A positive sign indicates an increase in density, while a decrease in sign indicates a decrease in density. The same analysis follows for all other regulatory variables and a summary of this analysis is presented in Table 9.

Table 9 - Expected Signs of Urban Regulation Variables Versus Density

\begin{tabular}{lcccccc}
\hline & $\begin{array}{c}\text { Min Plot } \\
\text { Area } \\
\left(\mathbf{m}^{2}\right)\end{array}$ & $\begin{array}{c}\text { Max } \\
\text { Fum }\end{array}$ & $\begin{array}{c}\text { Min } \\
\text { Front } \\
\text { Setback } \\
(\mathbf{m})\end{array}$ & $\begin{array}{c}\text { Fin } \\
\text { Fontage } \\
(\mathbf{m})\end{array}$ & $\begin{array}{c}\text { Occupati } \\
\text { on Ratio }\end{array}$ & $\begin{array}{c}\text { Floor-to- } \\
\text { Area } \\
\text { Ratio }\end{array}$ \\
\hline Increase in density of occupation & - & + & - & - & + & + \\
Decrease in density of occupation & + & - & + & + & - & - \\
\hline
\end{tabular}

With that in mind, let's turn back to the analysis of Table 8. Percentage of adults with 15 years of education or more is statistically different from zero on all models and in all cases the sign is consistent with an increase in density of occupation. That means that areas with higher percentages of high educational levels have a higher density of occupation. In the United States, high income families tend to locate in more suburban, less dense areas, while low income families tend to live in more central and densely occupied locations. Brazil, and many other developing countries, has the opposite trend. High income families locate in more central areas of the city, while the suburbs, where occupation is more spread out, is where low income families are concentrated. So the sign of the coefficients are what would be expected. 
The size of the population is statistically significant on the regressions of minimum plot area, minimum front setback and occupation ratio. In all cases, the sign of the coefficients indicate that as the size of the population increases, density of occupation increases as measured by these three regulatory variables, which is what we would expect. The magnitude of the effect of population size is particularly high for minimum plot size. A 1,000 increase in population is associated with a decrease in 76 $\mathrm{m} 2$ in the required minimum plot, meaning that in highly populated areas the plot size is smaller and the occupation is more compact.

The percentage of owner-occupied houses is only different from zero at the $90 \%$ level in the model of floor-to-area ratio. In this model, the sign of the coefficient indicates that places with a higher percentage of owner-occupied houses are associated with lower density of occupation. In all other models, the percentage of owner-occupied houses is not different from zero and we can't rule out the possibility that homeownership does not affect the stringency of regulation. Generally, one would expect homeownership to be associated with a segment of the population that has high income and is politically involved in influencing urban regulation. In Brazil, homeownership permeates all segments of society, with favelas and irregular loteamentos having high rates of homeownership. For that reason, it is not surprising that this variable doesn't seem to affect urban regulation. 
Finally, it is worth noting that this model of urban regulation performs particularly well with occupation ratio and FAR. In these regressions, the model explains $32 \%$ and $57 \%$ of the determinants of occupation ratio and FAR, respectively.

\section{Quantity of Informal Housing Model}

The third regression models the determinants of informal housing quantity with the function: $Q_{i}=f_{3}\left(P_{f}, N, L, I, D\right)$, where $Q_{i}$ is the quantity of informal houses measured as the houses where the owner doesn't have title to the land, $P_{f}$ is formal housing price, $N$ is a measure of neighborhood characteristics, $L$ is a measure of location within the market, $I$ is income, and $D$ is demographic characteristics measured by the size of the population, annual percentage change in population, number of people married, and percentage of families headed by blacks and pardos.

After running a linear model of the quantity of informal housing and identifying a cone relationship in the scatter plot between the residuals and the fitted values, a semi-log model is used to correct for this. The log-linear form correct for the nonconstant variance, but now a curvilinear relationship of the scatter plot between the residuals and the fitted values reveal the possibility of a non-linear relationship between the dependent and independent variables. The transformation of the variables for price, income, and size of the population, correct for this problem and the residual plot shows residuals randomly distributed around their mean of zero. 
Table 10 presents the results of the final regression model on the quantity of informal housing. All neighborhood attributes were insignificant. An F test statistic is carried out to check whether these variables are jointly significant and the test with $(5,92)$ degrees of freedom is 1.03 , meaning that all variables are jointly insignificant in explaining quantity of informal housing. The variables were also included in all three stage regressions and they were still insignificant, so they were dropped from the equation.

Table 10 - Quantity of Informal Housing Model

\begin{tabular}{lcccc}
\hline Dependent variable & Coefficient & $\begin{array}{c}\text { Standard } \\
\text { Error }\end{array}$ & $\boldsymbol{t}$-Statistic & Prob. $>|\mathbf{t}|$ \\
\hline Log Formal Housing Price (R\$) (2000) & -.1750937 & .1697956 & -1.03 & 0.305 \\
HH Median income (R\$) (2000) & -1.111925 & .2279704 & -4.88 & 0.000 \\
Size of population in 2000 (1,000) & -.0586821 & .0100282 & -5.85 & 0.000 \\
Square Root Size of population in 2000 & 1.170261 & .1237601 & 9.46 & 0.000 \\
Per. HH headed by blacks/pardos (2000) & .0242881 & .0139846 & 1.74 & 0.085 \\
Distance from downtown area (km) & -.023684 & .0166577 & -1.42 & 0.158 \\
Constant & 10.78352 & 2.337742 & 4.61 & 0.000 \\
\hline
\end{tabular}

Table 10 presents the regression on the natural logarithm of the quantity of housing where the owner owns the house but not the land according to the 2000 census. Number of observations $=108$ and R2 $=0.7953$

The model explains $79 \%$ of changes in the quantity of housing. The variables that are statistically significant at the $99 \%$ level are median income, population size, and the square root of population size. The percentage of households headed by blacks and pardos are statistically significant at the $95 \%$ level. Surprisingly, the price of formal housing and the distance from the downtown area are not statistically significant.

The coefficients obtained for population size indicate an increasing effect of population size on the quantity of informal housing, which is what would be expected. As population size increases, informal housing increases at a higher rate. 
Median income also has the expected negative sign, indicating that as median income increases, the quantity of informal housing decreases. The percentage of households headed by blacks and pardos is positive as expected.

\section{Three-Stage Least-Squares Regression}

The final models obtained in the single least squares regression were used to run a three-stage least squares regression that has the following equations:

Re gulation $=\beta_{10}+\beta_{11}$ Education _ $91+\beta_{12}$ Pop _ $91+\beta_{13}$ Owner $\_91+\varepsilon_{1}$

$\ln \left(P_{f}\right)=\beta_{20}+\alpha_{1}$ Re gulation $+\beta_{21}$ FloorSpace $+\beta_{22}$ Structure $+\beta_{23}$ Sewage + $\beta_{24}$ Water $+\beta_{25}$ Electricit $y+\beta_{26}$ Pavement $+\beta_{27}$ Dist $+\varepsilon_{2}$

$\ln \left(Q_{i}\right)=\beta_{30}+\alpha_{2} \ln \left(P_{f}\right)+\beta_{31} \ln \left(P_{f}\right)_{-W R 1}+\beta_{32} \ln \left(P_{f}\right)_{-W R 2}+\beta_{33} \ln \left(P_{f}\right)_{-W R 3}+$ $\beta_{34} \ln \left(P_{f}\right)_{-W D}+\beta_{35} \ln ($ Income $)+\beta_{36}$ Pop $+\beta_{37}$ Pop ${ }^{1 / 2}+\beta_{38}$ Black $+\beta_{39}$ Dist $+\varepsilon_{3}$

Where Regulation is each of the six regulatory variables (minimum plot area, maximum number of floors, minimum front setback, minimum frontage, occupation ratio, and FAR), $P_{f}$ is the price of formal housing, $Q_{i}$ is the quantity of informal housing, Income is the median household income, Education_91 is the percentage of adults with 15 years of education or more in 1991, Pop_91 is the size of the population in 1991, Owner_91 is the percentage of owner occupied houses in 1991, FloorSpace is the median floor space of formal housing in 2000, Structure is the 
percentage of houses with permanent structure in 2000, Sewage is the percentage of houses with sewage connection in 2000, Water is the percentage of houses with water connection in 2000, Electricity is the percentage of houses with electricity in 2000, Pavement is the percentage of houses with paved streets in 2000, Dist is the distance to the downtown area of Curitiba, Pop is the size of the population in 2000, and Black is the percentage of households headed by blacks or pardos.

In the third equation, the spatial lag variables $\ln \left(P_{f}\right)_{-} W R I, \quad \ln \left(P_{f}\right)_{-} W R 2, \ln \left(P_{f}\right)_{-} W R 3$, $\ln \left(P_{f}\right)_{-} W R 3, \ln \left(P_{f}\right)_{-} W D$ are introduced to the model. As explained before, these are not time lags, but spatial lag variables. $\operatorname{Ln}\left(P_{f}\right)_{-W R I}$ is the spatially lagged variable of the natural logarithm of formal housing price using a first order rook spatial weight. $\operatorname{Ln}\left(P_{f}\right)_{-W R 2}$ is the spatially lagged variable of the natural logarithm of formal housing price using a second order rook spatial weight. $\operatorname{Ln}\left(P_{f}\right)_{-} W_{3}$ is the spatially lagged variable of the natural logarithm of formal housing price using a third order rook spatial weight. And $\ln \left(P_{f}\right)_{-} W D$ is the spatially lagged variable of the natural logarithm of formal housing price using the distance-based weight. In all regressions the spatial lag variable that uses the forth order rook spatial weight, $\ln \left(P_{f}\right)_{-} W R 4$ is statistically insignificant, so this variable is not included in the final model specification.

Regulation, Natural Logarithm of Formal Housing Price $\ln \left(P_{f}\right)$, and the Natural Logarithm of Quantity of Informal Housing $\ln \left(Q_{i}\right)$ are endogenous variables, while all others are exogenous variables; $\alpha$ is used for parameters on endogenous variables, while $\beta$ is used for parameters on exogenous variables. 
Table 11 - Three-Stage Least-Squares Regression Model

\begin{tabular}{|c|c|c|c|c|c|c|}
\hline Regulatory Variables $(R)$ & $\begin{array}{l}\text { Min Plot } \\
\text { Area }\left(\mathbf{m}^{2}\right)\end{array}$ & $\begin{array}{l}\text { Max Num } \\
\text { Floors }\end{array}$ & $\begin{array}{l}\text { Min Front } \\
\text { Setback } \\
(\mathrm{m})\end{array}$ & $\begin{array}{c}\text { Min } \\
\text { Frontage } \\
(\mathbf{m})\end{array}$ & $\begin{array}{c}\text { Occupatio } \\
\text { Ratio }\end{array}$ & $\begin{array}{l}\text { Floor-to- } \\
\text { Area } \\
\text { Ratio }\end{array}$ \\
\hline \multicolumn{7}{|l|}{ Regulatory Variables $(R)$} \\
\hline $\begin{array}{l}\text { Size of population in } 1991 \\
(1,000)\end{array}$ & $\begin{array}{l}-79.70238 \\
(24.75728)\end{array}$ & $\begin{array}{l}-.0044029 \\
(.0046762)\end{array}$ & $\begin{array}{l}-.0703725 \\
(.020015)\end{array}$ & $\begin{array}{l}-.0641574 \\
(.049887)\end{array}$ & $\begin{array}{l}.0019847 \\
(.0007636)\end{array}$ & $\begin{array}{l}.0059144 \\
(.004409)\end{array}$ \\
\hline $\begin{array}{l}\text { Per. adults } \geq 15 \text { yrs of educ. in } \\
1991\end{array}$ & $\begin{array}{l}-203.3711 \\
(46.5878)\end{array}$ & $\begin{array}{l}.0366853 \\
(.0105515)\end{array}$ & $\begin{array}{l}-.1755692 \\
(.0337663)\end{array}$ & $\begin{array}{l}-.2027191 \\
(.0857639)\end{array}$ & $\begin{array}{l}.0097997 \\
(.0014271)\end{array}$ & $\begin{array}{l}.0545285 \\
(.0080833)\end{array}$ \\
\hline $\begin{array}{l}\text { Per. Owner Occupied Houses } \\
\text { in } 1991\end{array}$ & $\begin{array}{c}25.57384 \\
(40.30954)\end{array}$ & $\begin{array}{c}.0073816 \\
(.0074818)\end{array}$ & $\begin{array}{l}-.009094 \\
(.0292124)\end{array}$ & $\begin{array}{l}.0855584 \\
(.0763284)\end{array}$ & $\begin{array}{l}-.0005396 \\
(.0012395)\end{array}$ & $\begin{array}{l}-.0241442 \\
(.0126973)\end{array}$ \\
\hline Constant & $\begin{array}{c}5366.012 \\
(2447.061) \\
\end{array}$ & $\begin{array}{l}1.71235 \\
(.4746202) \\
\end{array}$ & $\begin{array}{c}11.10072 \\
(1.752635)\end{array}$ & $\begin{array}{r}14.79474 \\
(4.787504) \\
\end{array}$ & $\begin{array}{l}.3185525 \\
(.0745459) \\
\end{array}$ & $\begin{array}{c}1.995542 \\
(.8440507) \\
\end{array}$ \\
\hline \multicolumn{7}{|l|}{$\operatorname{Ln}\left(P_{f}\right)$} \\
\hline Regulatory Variables $(R)$ & $\begin{array}{l}0.0000674 \\
(.0000196)\end{array}$ & $\begin{array}{l}.474286 \\
(.1058152)\end{array}$ & $\begin{array}{l}.0676246 \\
(.0321528)\end{array}$ & $\begin{array}{l}.0254027 \\
(.0105803)\end{array}$ & $\begin{array}{l}-.0094705 \\
(.5775187)\end{array}$ & $\begin{array}{l}.1839158 \\
(.089103)\end{array}$ \\
\hline Floor space (m2) & $\begin{array}{l}0.0096312 \\
(.0013601)\end{array}$ & $\begin{array}{l}.0065718 \\
(.0014468)\end{array}$ & $\begin{array}{l}.0108406 \\
(.0016894)\end{array}$ & $\begin{array}{l}.0071105 \\
(.0015165)\end{array}$ & $\begin{array}{l}.0089811 \\
(.0014345)\end{array}$ & $\begin{array}{l}.0104866 \\
(.0019384)\end{array}$ \\
\hline $\begin{array}{l}\text { Per. Houses w/ Permanent } \\
\text { Structure in } 2000\end{array}$ & $\begin{array}{l}-.2096847 \\
(.0747493)\end{array}$ & $\begin{array}{l}-.0580339 \\
(.0873378)\end{array}$ & $\begin{array}{l}-.2587959 \\
(.0955257)\end{array}$ & $\begin{array}{l}-.2123095 \\
(.1165552)\end{array}$ & $\begin{array}{l}-.1968338 \\
(.0931459)\end{array}$ & $\begin{array}{l}-.1272995 \\
(.0731264)\end{array}$ \\
\hline $\begin{array}{l}\text { Per. of Houses w/ Sewage } \\
\text { Connection in } 2000\end{array}$ & $\begin{array}{l}.0035151 \\
(.002205)\end{array}$ & $\begin{array}{l}.0008292 \\
(.0026537)\end{array}$ & $\begin{array}{l}.0030247 \\
(.0021695)\end{array}$ & $\begin{array}{l}.0031464 \\
(.0025063)\end{array}$ & $\begin{array}{l}.0019753 \\
(.0022781)\end{array}$ & $\begin{array}{l}.0012053 \\
(.0026423)\end{array}$ \\
\hline $\begin{array}{l}\text { Per. Houses w/ Water } \\
\text { Connection in } 2000\end{array}$ & $\begin{array}{l}-.0058627 \\
(.0051279)\end{array}$ & $\begin{array}{c}-.007767 \\
(.0055479)\end{array}$ & $\begin{array}{l}-.0092815 \\
(.0045138)\end{array}$ & $\begin{array}{l}-.0042823 \\
(.0075145)\end{array}$ & $\begin{array}{l}-.0104946 \\
(.0050949)\end{array}$ & $\begin{array}{l}-.0047413 \\
(.0051356)\end{array}$ \\
\hline $\begin{array}{l}\text { Per. Houses w/ Electricity in } \\
2000\end{array}$ & $\begin{array}{l}.2140479 \\
(.075396)\end{array}$ & $\begin{array}{l}.0493092 \\
(.0881079)\end{array}$ & $\begin{array}{l}.2641156 \\
(.0965953)\end{array}$ & $\begin{array}{c}.206694 \\
(.1159401)\end{array}$ & $\begin{array}{l}.1992205 \\
(.0931702)\end{array}$ & $\begin{array}{l}.1165355 \\
(.073172)\end{array}$ \\
\hline $\begin{array}{l}\text { Per. Houses w/ Paved Streets } \\
\text { in } 2000\end{array}$ & $\begin{array}{l}.0013143 \\
(.0027499)\end{array}$ & $\begin{array}{c}.005719 \\
(.0029935)\end{array}$ & $\begin{array}{l}.0030273 \\
(.0031108)\end{array}$ & $\begin{array}{l}.008301 \\
(.0030725)\end{array}$ & $\begin{array}{l}.0001675 \\
(.0027908)\end{array}$ & $\begin{array}{l}-.0015626 \\
(.0031943)\end{array}$ \\
\hline $\begin{array}{l}\text { Distance from downtown area } \\
(\mathrm{km})\end{array}$ & $\begin{array}{l}-.0495509 \\
(.0112996)\end{array}$ & $\begin{array}{l}-.0255989 \\
(.0101968)\end{array}$ & $\begin{array}{l}-.033895 \\
(.0109858)\end{array}$ & $\begin{array}{l}-.042583 \\
(.0112472)\end{array}$ & $\begin{array}{l}-.0421285 \\
(.0111455)\end{array}$ & $\begin{array}{l}-.0361481 \\
(.009378)\end{array}$ \\
\hline Constant & $\begin{array}{l}9.127037 \\
(.8080231) \\
\end{array}$ & $\begin{array}{c}9.516872 \\
(.7877929) \\
\end{array}$ & $\begin{array}{l}8.668575 \\
(1.03123) \\
\end{array}$ & $\begin{array}{c}9.408996 \\
(1.242219) \\
\end{array}$ & $\begin{array}{c}10.12716 \\
(.6974655) \\
\end{array}$ & $\begin{array}{l}10.57928 \\
(1.24512) \\
\end{array}$ \\
\hline \multicolumn{7}{|l|}{$\operatorname{Ln}\left(Q_{i}\right)$} \\
\hline $\operatorname{Ln}\left(P_{f}\right)$ & $\begin{array}{l}-1.041704 \\
(.3771279)\end{array}$ & $\begin{array}{c}-.235924 \\
(.5223928)\end{array}$ & $\begin{array}{l}-1.053326 \\
(.393119)\end{array}$ & $\begin{array}{l}.5944381 \\
(.7760126)\end{array}$ & $\begin{array}{l}-.9391618 \\
(.3894187)\end{array}$ & $\begin{array}{l}.0574916 \\
(.2589183)\end{array}$ \\
\hline $\operatorname{Ln}\left(P_{f}\right) \_\mathrm{WR} 1$ & $\begin{array}{l}.7912228 \\
(.3487083)\end{array}$ & $\begin{array}{l}.0626943 \\
(.439931)\end{array}$ & $\begin{array}{l}.678916 \\
(.3593166)\end{array}$ & $\begin{array}{l}-.4137277 \\
(.4834184)\end{array}$ & $\begin{array}{l}.5927712 \\
(.3429455)\end{array}$ & $\begin{array}{l}-.2424379 \\
(.4146127)\end{array}$ \\
\hline $\operatorname{Ln}\left(P_{f}\right)_{-} \mathrm{WR} 2$ & $\begin{array}{l}-.2727008 \\
(.4088401)\end{array}$ & $\begin{array}{l}.7057669 \\
(.4726501)\end{array}$ & $\begin{array}{l}-.2301704 \\
(.4575036)\end{array}$ & $\begin{array}{l}.761779 \\
(.5029874)\end{array}$ & $\begin{array}{c}-.206925 \\
(.4481875)\end{array}$ & $\begin{array}{l}-.2659329 \\
(.5716497)\end{array}$ \\
\hline $\operatorname{Ln}\left(P_{f}\right)_{-} \mathrm{WR} 3$ & $\begin{array}{l}1.019145 \\
(.5297675)\end{array}$ & $\begin{array}{l}.5772361 \\
(.5516105)\end{array}$ & $\begin{array}{c}1.149548 \\
(.5658766)\end{array}$ & $\begin{array}{l}.552582 \\
(.6068983)\end{array}$ & $\begin{array}{c}1.073931 \\
(.5500663)\end{array}$ & $\begin{array}{l}.8861025 \\
(.5399613)\end{array}$ \\
\hline $\operatorname{Ln}\left(P_{f}\right)_{-} \mathrm{WD}$ & $\begin{array}{l}.1461535 \\
(.3546275)\end{array}$ & $\begin{array}{l}.4311134 \\
(.3601063)\end{array}$ & $\begin{array}{l}-.1397949 \\
(.3622848)\end{array}$ & $\begin{array}{l}.960636 \\
(.5348956)\end{array}$ & $\begin{array}{l}.0540064 \\
(.3551959)\end{array}$ & $\begin{array}{l}.9501028 \\
(.3521032)\end{array}$ \\
\hline Ln (Median income in 2000) & $\begin{array}{l}-1.335793 \\
(.2741911)\end{array}$ & $\begin{array}{l}-2.024781 \\
(.3417869)\end{array}$ & $\begin{array}{l}-1.349411 \\
(.2814806)\end{array}$ & $\begin{array}{l}-2.21359 \\
(.451582)\end{array}$ & $\begin{array}{l}-1.278351 \\
(.2784935)\end{array}$ & $\begin{array}{l}-.5523495 \\
(.3052314)\end{array}$ \\
\hline $\begin{array}{l}\text { Size of population in } 2000 \\
(1,000)\end{array}$ & $\begin{array}{l}-.0588314 \\
(.0097637)\end{array}$ & $\begin{array}{l}-.0469691 \\
(.010809)\end{array}$ & $\begin{array}{l}-.0604626 \\
(.0115069)\end{array}$ & $\begin{array}{l}-.0523679 \\
(.013154)\end{array}$ & $\begin{array}{l}-.0552361 \\
(.0099846)\end{array}$ & $\begin{array}{l}-.0334004 \\
(.0111214)\end{array}$ \\
\hline $\begin{array}{l}\text { Square Root (Size of } \\
\text { population in 2000) }\end{array}$ & $\begin{array}{l}1.158518 \\
(.1206044)\end{array}$ & $\begin{array}{l}1.042693 \\
(.1366591)\end{array}$ & $\begin{array}{c}1.186371 \\
(.1363582)\end{array}$ & $\begin{array}{c}1.109423 \\
(.1546656)\end{array}$ & $\begin{array}{l}1.138403 \\
(.1249628)\end{array}$ & $\begin{array}{l}.8350453 \\
(.1452782)\end{array}$ \\
\hline $\begin{array}{l}\text { Per. HH headed by } \\
\text { blacks/pardos (2000) }\end{array}$ & $\begin{array}{l}.0057962 \\
(.0180512)\end{array}$ & $\begin{array}{l}-.0036871 \\
(.0218054)\end{array}$ & $\begin{array}{l}.0037548 \\
(.0191758)\end{array}$ & $\begin{array}{l}-.0081042 \\
(.0198524)\end{array}$ & $\begin{array}{l}.0092369 \\
(.0189644)\end{array}$ & $\begin{array}{l}.0448271 \\
(.0151923)\end{array}$ \\
\hline $\begin{array}{l}\text { Distance from downtown area } \\
(\mathrm{km})\end{array}$ & $\begin{array}{l}-.0092349 \\
(.0360166)\end{array}$ & $\begin{array}{l}.0244744 \\
(.035271)\end{array}$ & $\begin{array}{l}-.0295273 \\
(.0379392)\end{array}$ & $\begin{array}{l}.0946695 \\
(.0677703)\end{array}$ & $\begin{array}{l}-.0141282 \\
(.0375841)\end{array}$ & $\begin{array}{c}.055976 \\
(.0257034)\end{array}$ \\
\hline Constant & $\begin{array}{l}4.220569 \\
(6.97565) \\
\end{array}$ & $\begin{array}{l}-.1296983 \\
(6.747601) \\
\end{array}$ & $\begin{array}{l}6.913298 \\
(7.14041) \\
\end{array}$ & $\begin{array}{l}-8.921182 \\
(10.33251) \\
\end{array}$ & $\begin{array}{l}4.504076 \\
(7.05438) \\
\end{array}$ & $\begin{array}{l}-9.271621 \\
(5.645365) \\
\end{array}$ \\
\hline $\mathrm{N}$ & 108 & 82 & 101 & 83 & 104 & 39 \\
\hline
\end{tabular}


Five of six regulatory variables are significant in the formal housing price model. Minimum plot area and maximum number of floors are significant at the $99 \%$ level. Minimum front setback, minimum frontage, and FAR are significant at the $95 \%$ level. Some of the results confirm the original predictions of the study. An increase in minimum plot area, minimum front setback and minimum frontage would decrease density of occupation of land and in these regressions they show a positive effect on formal housing price, which is consistent with the hypothesis that more restrictive regulations increase housing price. According to these results, holding other quality attributes of a residence fixed, a $100 \mathrm{~m} 2$ increase in required minimum plot area will increase the median price of formal housing by approximately $0.7 \%$; a $1 \mathrm{~m}$ increase in the required minimum front setback will increase the median price of formal housing by approximately $7 \%$; and a $1 \mathrm{~m}$ increase in the required minimum frontage will increase the median price of formal housing by approximately $2.5 \%$.

For two regulatory variables the results are conflicting. An increase in maximum number of floors and an increase in FAR would increase density and in both cases they are associated with a positive effect on price, which is contrary to what we would expect according to the original hypothesis. According to these results, holding other structural, neighborhood and location attributes of a housing unit fixed, permitting an additional floor will increase median housing price by $47.4 \%$ and increasing FAR by 1 point will increase median housing price by $18.4 \%$. 
Both maximum number of floors and FAR are regulatory variables that are highly correlated and have a direct effect on building height. Zoning areas where more floors and higher FAR are permitted tend to have more multistory residential buildings (remember that FAR is the ratio between building floor space and plot area, so that a FAR of three means that on that parcel of land, buildings can have floor space that is three times the area of the plot). It is possible that this apparent discrepancy is actually the result of aggregating single family and multifamily units in the analysis. Ideally, we would like to study these two markets separately, but in this case, the data doesn't permit it.

There were two other hypotheses being tested. The second hypothesis proposed that formal housing is an imperfect substitute for informal housing, so that an increase in formal housing price would increase the quantity of informal housing. The third hypothesis proposed that there is a spatial interaction of formal housing prices and informal housing so that an increase in housing price in one area will lead low income families to look for a housing solution in the informal market not only in that area, but also in neighboring areas. The spatial spillover effect was to be assessed through spatially lagged variables of formal housing price. There are five regressions where at least one of the formal housing price variables has a statistically significant effect on the quantity of informal housing.

Table 12 highlights the results for the formal housing price variables that are statistically significant. $\operatorname{Ln}\left(P_{f}\right)$ is the natural logarithm of formal housing price and the 
coefficient shows the effect of this variable on the natural logarithm of the quantity of informal housing $\ln \left(Q_{i}\right)$ obtained from the three-stage regression models described above. $\operatorname{Ln}\left(P_{f}\right)_{-W R I}$ is the spatial lag of the natural logarithm of formal housing price using a first order rook weight, while $\ln \left(P_{f}\right)_{-W R 3}$ is the spatial lag variable using third order rook weight and $\ln \left(P_{f}\right)_{-W D}$ is the spatial lag variable using a distance-based weight.

Table 12 - Summary of the Effect of Formal Housing Price on the Quantity of Informal Housing

\begin{tabular}{|c|c|c|c|}
\hline Three-Stage Regression Model & Variable & Coefficient & Significance Level \\
\hline \multirow[t]{3}{*}{ Minimum Plot Area (m2) } & $\operatorname{Ln}\left(P_{f}\right)$ & -1.041704 & $99 \%$ \\
\hline & $\operatorname{Ln}\left(P_{f}\right)_{-W R I}$ & .7912228 & $95 \%$ \\
\hline & $\operatorname{Ln}(\mathrm{Pf})_{-} W R 3$ & 1.019145 & $90 \%$ \\
\hline \multirow[t]{3}{*}{ Minimum Front Setback (m) } & $\operatorname{Ln}\left(P_{f}\right)$ & -1.053326 & $99 \%$ \\
\hline & $\operatorname{Ln}\left(P_{f}\right)_{-W R I}$ & .678916 & $90 \%$ \\
\hline & $\operatorname{Ln}(\mathrm{Pf})_{-W R 3}$ & 1.1495486 & $95 \%$ \\
\hline Minimum Frontage (m) & $\operatorname{Ln}\left(P_{f}\right)_{-W D}$ & .960636 & $90 \%$ \\
\hline \multirow[t]{3}{*}{ Occupation Ratio } & $\operatorname{Ln}\left(P_{f}\right)$ & -.9391618 & $95 \%$ \\
\hline & $\operatorname{Ln}\left(P_{f}\right) \_W R I$ & .5927712 & $90 \%$ \\
\hline & $\operatorname{Ln}(\mathrm{Pf})_{-W R 3}$ & 1.073931 & $90 \%$ \\
\hline Floor-to-Area Ratio (FAR) & $\operatorname{Ln}\left(P_{f}\right)_{-W D}$ & .95010288 & $99 \%$ \\
\hline
\end{tabular}

The five regressions highlighted here indicate that the price of formal housing has a negative effect on the quantity of informal housing in the same neighborhood, but this effect turns positive in the adjacent and more distant neighborhoods. As expected, the rise in formal housing price in one locality pushes people to the informal sector in more distant neighborhoods, confirming the third hypothesis. However, in the same locality the results are not what were expected. A rise in formal housing price in one locality decreases the amount of informal housing in that locality, contrary to the second hypothesis. 
In the three-stage regression that uses the regulatory variable minimum plot area, the results show that a $1 \%$ increase in formal housing price would decrease the quantity of informal housing by $1.04 \%$ in the same neighborhood, and increase it by $0.79 \%$ and $1.02 \%$ in first and third order neighbors, respectively. In the three-stage regression that uses the regulatory variable minimum front setback, the results show that a $1 \%$ increase in formal housing price would decrease the quantity of informal housing by $1.05 \%$ in the same neighborhood and increase it by $0.68 \%$ and $1.15 \%$ in first and third order neighbors, respectively. In the three-stage regression that uses the regulatory variable occupation ratio, the results show that a $1 \%$ increase in formal housing price would decrease the quantity of informal housing by $0.94 \%$ in the same neighborhood and increase it by $0.59 \%$ and $1.07 \%$ in first and third order neighbors, respectively. In the three-stage regression that uses the regulatory variable minimum frontage, the results show that a $1 \%$ increase in formal housing price would increase the quantity of informal housing by $0.96 \%$ in neighboring locations. In the three-stage regression that uses the regulatory variable floor-to-area ratio, the results show that a $1 \%$ increase in formal housing price would increase the quantity of informal housing by $0.95 \%$ in neighboring locations.

What could explain the apparent discrepancy in these results? The theory that has been recently developed to explain the existence and sustainability of informal housing by Brueckner and Selod (2008) might help understand this paradox. In their model, Brueckner and Selod propose that squatters and formal residents compete for land within a city. The model portrays squatters as "squeezing" the formal market by 
occupying land that could be developed for formal use, raising the price paid by formal residents. The squatter organizer, however, ensures that this squeezing is not too severe, otherwise the formal price will rise to a level that invites eviction by landowners.

It is possible that these results are reflecting the spatial manifestation of this phenomenon. As the formal housing price rises in a particular neighborhood, the possibility of eviction becomes too high in that location leading low income families to look for an informal housing solution in a different location. What seems to be different from Brueckner and Selod's conclusion is that the model developed here seems to show that the formal sector is not being "squeezed" by the informal one, but rather that the formal housing sector, by maintaining high prices in certain locations, is keeping the informal housing sector out of their areas, pushing them to more distant and less desirable locations.

Recall the LISA cluster map that was presented in the spatial analysis section (see Figure 26 below). 


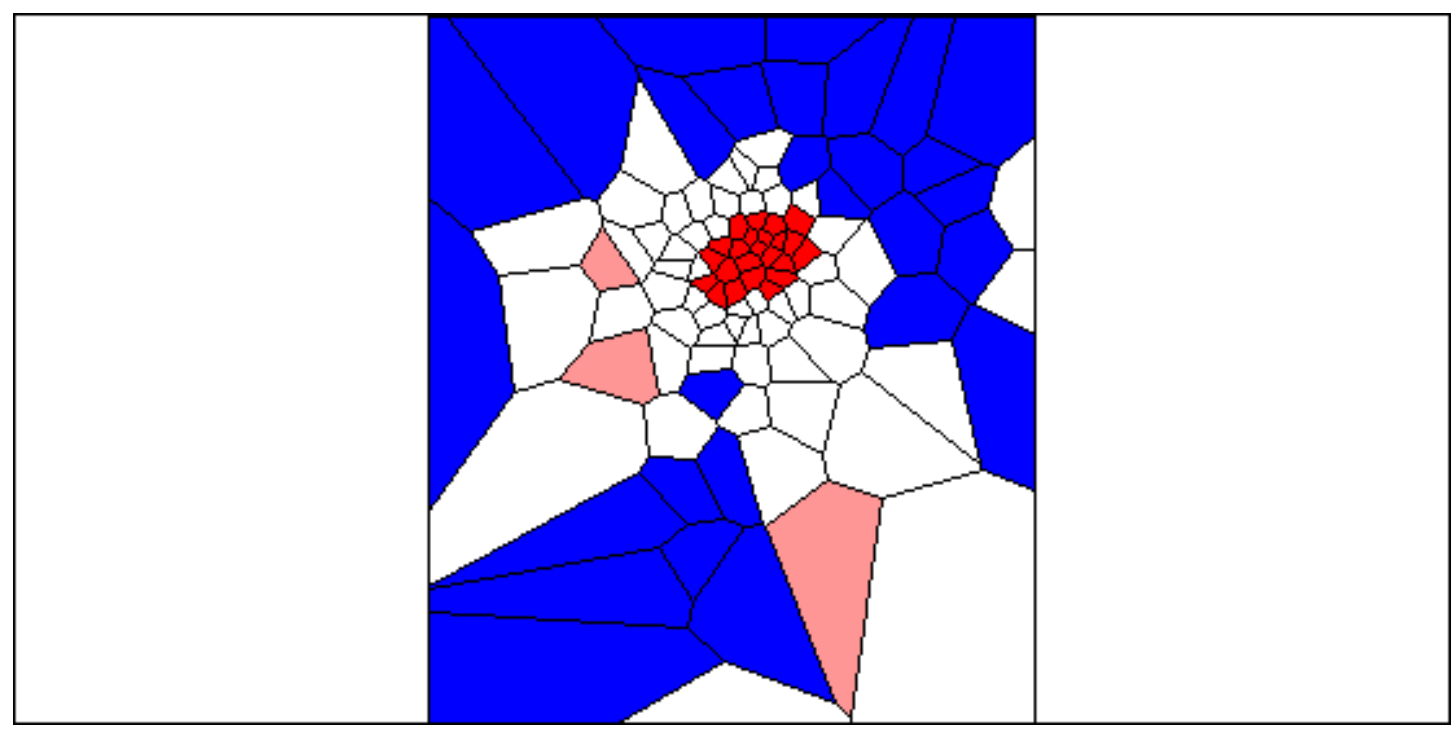

Figure 26 - LISA Cluster Map of Formal Housing Price Variable

Using First Order Rook Weight

999 permutations, significance level $p=0.05$

This map showed that there was clustering of high formal housing prices at the center (in red) and clustering of low formal housing prices in the periphery (in blue). The zones in dark red are those that have a high-high significant spatial correlation (high housing price zones surrounded by high housing price zones). The zones in dark blue have low-low significant spatial autocorrelation (low housing price zones surrounded by low housing price zones). The zones in light red are outliers and have significant high-low spatial autocorrelation (a zone with high housing price surrounded by zones with low housing price). Zones in white have no significant spatial correlation.

Based on the spatial correlation of formal housing price, it was anticipated that more distant neighbors were more likely to have a positive and significant effect on the quantity of informal housing and this is what the results are showing. From first order neighbors to third order neighbors there is an increase in the magnitude of the effect of formal price on informal quantity of housing. In the minimum plot area regression 
model, there is an increase in the magnitude of the coefficient from $0.79 \%$ to $1.02 \%$; in the minimum front setback model, it increases from $0.68 \%$ to $1.15 \%$; and in the occupation ratio model it increases from $0.59 \%$ to $1.07 \%$.

The comparison of the LISA cluster map for formal housing price with the LISA cluster map for the quantity of informal housing (see Figure 27) shows that the informal housing variable has a significant spatial correlation predominantly concentrated in the center of the city, and in the rest of the metropolitan area there isn't a clear pattern of spatial correlation. In the central locations two spatial patterns occur: high-high significant spatial correlation for formal housing price and low-low significant spatial correlation for quantity of informal housing.

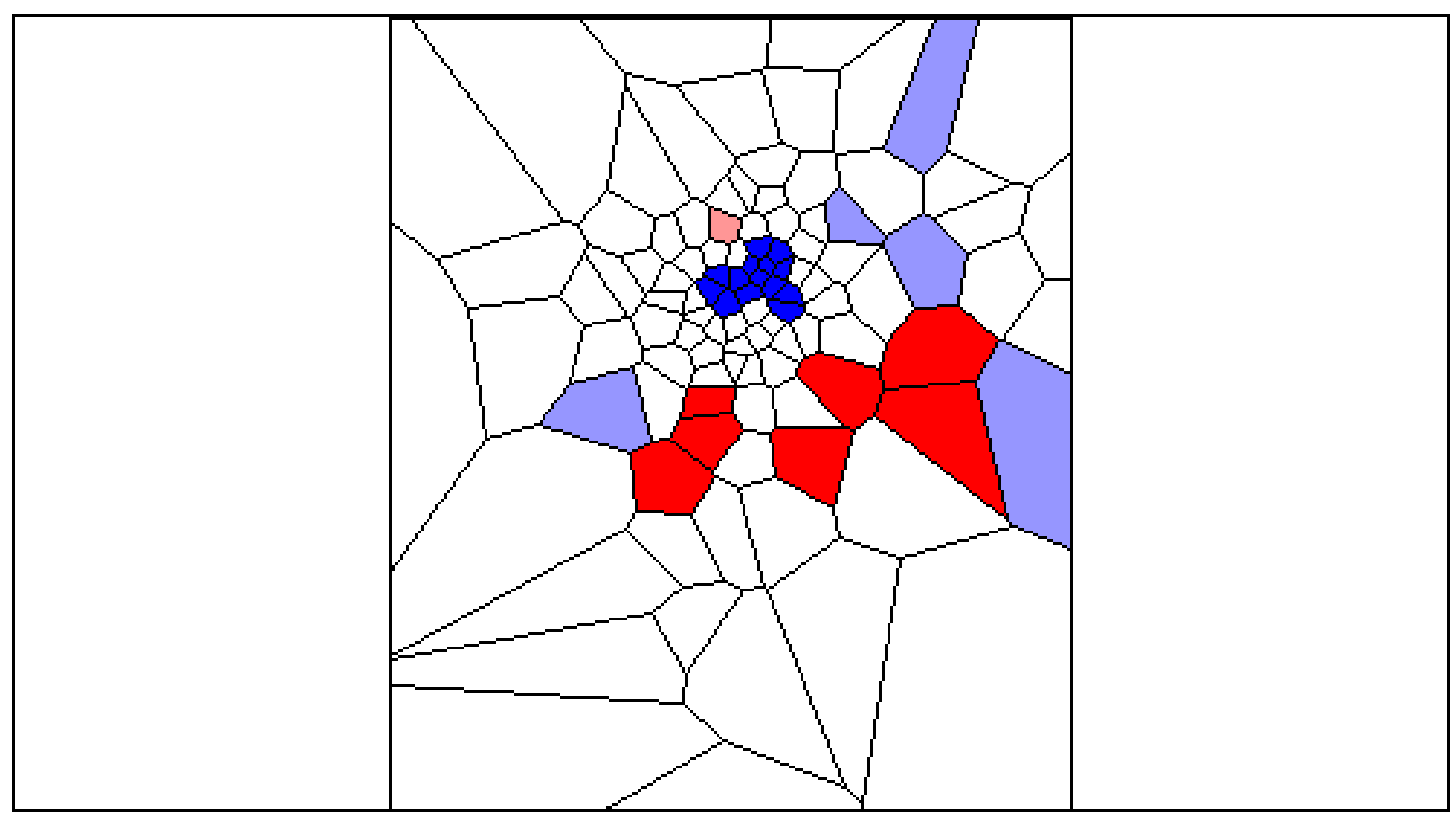

Figure 27 - LISA Cluster Map of Quantity of Informal Housing Variable Using First Order Rook Weight

999 permutations, significance level $p=0.05$ 
The results indicate that high priced areas act as a bar to the development of the informal sector in the same locality (explaining the negative coefficients of formal housing price) while the informal sector is being pushed to the outskirts of the city (explaining why the lagged price variables become positive and have an increasing effect on the quantity of informal housing as the locations move further away from each other).

The regressions results also seem to indicate that the net effect of formal housing price on the quantity of informal housing, taking into consideration the effect on the same location and the effect on neighboring locations, is positive. This regression shows that without a spatial analysis, the results of the effect of price on informality can be misleading.

\section{Single Versus Three-Stage Least-Squares Regression}

The same model specifications used in the three-stage regressions were run separately to test whether the use of a simultaneous equation model improves results in comparison with a model specification that uses single regressions. The results are show in Table 13, Table 14, and Table 15.

In the first equation, which models the determinants of urban regulation and is presented in Table 13, simultaneity doesn't affect the results much. All variables in the single regression have coefficients with similar significance level, sign and 
magnitude as the three-stage regression. This is expected, as this equation doesn't have a variable that is jointly determined by another equation.

Table 13 - Urban Regulation Model

\begin{tabular}{lcrrrrr}
\hline & $\begin{array}{c}\text { Min Plot } \\
\text { Area }\left(\mathbf{m}^{\mathbf{2}}\right)\end{array}$ & $\begin{array}{c}\text { Max Num } \\
\text { Floors }\end{array}$ & $\begin{array}{c}\text { Min Front } \\
\text { Setback } \\
(\mathbf{m})\end{array}$ & $\begin{array}{c}\text { Min } \\
\text { Frontage } \\
(\mathbf{m})\end{array}$ & $\begin{array}{c}\text { Occupatio } \\
\text { Ratio }\end{array}$ & $\begin{array}{c}\text { Floor-to- } \\
\text { Area Ratio }\end{array}$ \\
\hline Per. adults $\geq 15$ yrs of & -223.4458 & .0366568 & -.1805736 & -.236503 & .0096476 & .0542588 \\
educ. (1991) & $(47.86157)$ & $(.0116276)$ & $(.0344986)$ & $(.0886127)$ & $(.0014564)$ & $(.0085636)$ \\
Size of population in & -76.11268 & -.0012274 & -.0697854 & -.0511663 & .0020517 & .0057808 \\
1991 (1,000) & $(25.69132)$ & $(.0064268)$ & $(.0204543)$ & $(.0521473)$ & $(.0007797)$ & $(.0046972)$ \\
Per. owner occupied & 29.07814 & .0078691 & -.0104602 & .0776651 & -.0005685 & -.0251985 \\
house (1991) & $(41.96922)$ & $(.0101846)$ & $(.0299132)$ & $(.0796398)$ & $(.0012675)$ & $(.0135324)$ \\
Constant & 5285.143 & 1.621966 & 11.22438 & 15.44212 & .320643 & 2.067878 \\
& $(2544.444)$ & $(.6196109)$ & $(1.794326)$ & $(4.988589)$ & $(.0762075)$ & $(.8996261)$ \\
\hline N & 108 & 82 & 101 & 83 & 104 & 39 \\
$\mathrm{R}^{2}$ & 0.21 & 0.14 & 0.29 & 0.09 & 0.32 & 0.57 \\
\hline
\end{tabular}

In each cell, coefficients are shown on the top and standard errors are shown in parenthesis at the bottom. Coefficients highlighted in dark green are significant at the $99 \%$ level, coefficients highlighted in light green are significant at the $95 \%$ level, and coefficients highlighted in yellow are significant at the $90 \%$ level.

In the second equation, which models the determinants of formal housing price and is presented in Table 14, results between single and three-stage regressions start to differ. In the simultaneous model, where the regulatory variables are treated as endogenous in the model, five out of six regulatory variables are significant, while in the single regression model, only two variables are significant. Minimum plot area and maximum number of floors don't have a significant effect on formal housing price in the single regression, while they are significant at the $99 \%$ level in the threestage regression model. Minimum frontage doesn't have a significant effect on formal housing price in the single regression, while it is significant at the $95 \%$ level in the three-stage regression model. There are two regulatory variables which are significant for both models: minimum front setback and floor-to-area ratio. In both model specifications, the sign is the same and the magnitude of the effect is very similar. 
Occupation ratio is the only regulatory variable which doesn't show a significant effect on formal housing price in both models.

Table 14 - Formal Housing Price Model

\begin{tabular}{lcccccc}
\hline Dependent variable & $\begin{array}{c}\text { Min Plot } \\
\text { Area }\left(\mathbf{m}^{2}\right)\end{array}$ & $\begin{array}{c}\text { Max Num } \\
\text { Floors }\end{array}$ & $\begin{array}{c}\text { Min Front } \\
\text { Setback } \\
(\mathbf{m})\end{array}$ & $\begin{array}{c}\text { Min } \\
\text { Frontage } \\
(\mathbf{m})\end{array}$ & $\begin{array}{c}\text { Occupatio } \\
\text { n Ratio }\end{array}$ & $\begin{array}{c}\text { Floor-to- } \\
\text { Area Ratio }\end{array}$ \\
\hline Regulatory Variables & .0000128 & .0261418 & .0434567 & -.0009023 & -.1148632 & .1438347 \\
$(R)$ & $(.0000105)$ & $(.0390144)$ & $(.0137177)$ & $(.0058452)$ & $(.3611763)$ & $(.079632)$ \\
Floor space (m2) & .0089502 & .0076459 & .0101877 & .0069215 & .0090135 & .0105738 \\
& $(.0014212)$ & $(.0014929)$ & $(.0015023)$ & $(.0015502)$ & $(.0014971)$ & $(.0021814)$ \\
Per. Houses w/ Perm. & -.176489 & -.1049189 & -.2478691 & -.1073266 & -.195851 & -.1329349 \\
Structure in 2000 & $(.0789996)$ & $(.0989313)$ & $(.0987747)$ & $(.1075602)$ & $(.1029516)$ & $(.0839986)$ \\
Per. of Houses w/ & .003053 & .0034794 & .0032133 & .0024629 & .0027836 & .0014862 \\
Sewage in 2000 & $(.0023825)$ & $(.0027854)$ & $(.0024203)$ & $(.0025875)$ & $(.0025296)$ & $(.0030373)$ \\
Per. Houses w/ Water & -.0112109 & -.0111258 & -.0105422 & -.0085145 & -.0116424 & -.0052951 \\
Connection in 2000 & $(.0050431)$ & $(.0057624)$ & $(.0050411)$ & $(.0074738)$ & $(.0053955)$ & $(.0057765)$ \\
Per. Houses w/ & .1786117 & .0967876 & .2515263 & .1056282 & .1965335 & .1207124 \\
Electricity in 2000 & $(.0793275)$ & $(.0996313)$ & $(.0988126)$ & $(.1077936)$ & $(.1027654)$ & $(.0841131)$ \\
Per. Houses w/ Paved & .0019978 & .0076442 & .0036954 & .0084262 & .0017242 & -.0012706 \\
Streets in 2000 & $(.0029543)$ & $(.0033284)$ & $(.0030545)$ & $(.0031767)$ & $(.0031193)$ & $(.0036723)$ \\
Distance from & -.0368457 & -.0252274 & -.0294457 & -.0381546 & -.0360818 & -.0362793 \\
downtown area (km) & $(.0114628)$ & $(.0114244)$ & $(.0113941)$ & $(.0114374)$ & $(.0118645)$ & $(.0106869)$ \\
Constant & 9.935257 & 10.46446 & 9.102939 & 9.854758 & 10.22194 & 10.77491 \\
& $(.7944957)$ & $(.7696089)$ & $(.8246046)$ & $(1.272625)$ & $(.7883381)$ & $(1.433307)$ \\
\hline $\mathrm{N}$ & 108 & 82 & 101 & 83 & 104 & 39 \\
\hline $\mathrm{R}^{2}$ & 0.7551 & 0.7959 & 0.7499 & 0.8206 & 0.7307 & 0.8970 \\
\hline
\end{tabular}

Table 14 presents the regression on natural logarithm of formal housing price, measured by the median assessed price of residential units used by municipalities for property tax purposes.

In the third equation, which models the determinants of informal housing quantity and is presented in Table 15, results between single and three-stage regressions differ. In the simultaneous model, where formal housing price is treated as endogenous in the model, formal housing price has a significant effect on the quantity of informal housing in four out of six of the model specifications, while in the single regression formal housing price has no significant effect on informal housing. These results indicate that the regulatory and the formal housing price variables must be endogenous and the use of a three-stage regression model is recommended. 
Table 15 - Quantity of Informal Housing Model

\begin{tabular}{|c|c|c|c|c|}
\hline Dependent variable & Coefficient & $\begin{array}{r}\text { Standard } \\
\text { Error } \\
\end{array}$ & $t$-Statistic & Prob. $>|t|$ \\
\hline $\operatorname{Ln}\left(P_{f}\right)$ & -.2511294 & .1737462 & -1.45 & 0.152 \\
\hline $\operatorname{Ln}\left(P_{f}\right) \_\mathrm{WR} 1$ & .5055161 & .3239525 & 1.56 & 0.122 \\
\hline $\operatorname{Ln}\left(P_{f}\right)_{-} \mathrm{WR} 2$ & -.0424004 & .3998636 & -0.11 & 0.916 \\
\hline $\operatorname{Ln}\left(P_{f}\right) \_\mathrm{WR} 3$ & .677731 & .5162239 & 1.31 & 0.192 \\
\hline $\operatorname{Ln}\left(P_{f}\right)_{-} \mathrm{WD}$ & .1138165 & .3426699 & 0.33 & 0.740 \\
\hline Ln (Median income in 2000) & -1.430111 & .2749851 & -5.20 & 0.000 \\
\hline Size of population in $2000(1,000)$ & -.0583599 & .009983 & -5.85 & 0.000 \\
\hline Square Root (Size of population 2000) & 1.181749 & .123442 & 9.57 & 0.000 \\
\hline $\begin{array}{l}\text { Per. HH headed by blacks/pardos } \\
(2000)\end{array}$ & .0213085 & .0144699 & 1.47 & 0.144 \\
\hline Distance from downtown area $(\mathrm{km})$ & .0211316 & .0318785 & 0.66 & 0.509 \\
\hline Constant & .5627719 & 6.515571 & 0.09 & 0.931 \\
\hline
\end{tabular}




\section{Chapter 6: Discussion}

The accelerated urban growth that is taking place in developing countries and the important role played by the informal sector in housing low and moderate income households has brought renewed attention to the understanding of the determinants of informal housing and the role played by land use regulations. Until recently, the literature either focused on the determinants of housing price, without incorporating the informal sector in the analysis, or described the operation of the informal market without much emphasis on the specific economic mechanisms that lead to the emergence of informal settlements. Some studies have started to address these shortcomings in the literature by formulating formal theories about the emergence of informal settlements and by carrying out empirical work to understand their determinants. However, there have been conflicting results and there are still several unanswered questions about how urban regulation affects formal housing price and informality, and how formal housing price affects or is affected by informality.

The purpose of the present study was to address some of these questions by investigating three hypothesis: (a) more restrictive land use regulation increases housing price in the formal housing market; (b) an increase in formal housing price causes the quantity of informal housing to rise; and (c) an increase in formal housing price in one area causes the quantity of informal housing to rise in neighboring areas. 


\section{Overview of the Findings of the Study}

The effect of land use regulation on formal housing price

There is extensive literature on this topic and, in general, most authors have found that more restrictive land use regulation increases the price of formal housing. To address some of the shortcomings of previous studies in developing countries, my research: (i) tested the hypothesis in a local market instead of analyzing an aggregated national market as many studies in developing countries have done; (ii) used a quantitative analysis to estimate the magnitude of the effect of land use regulation; (iii) treated urban regulation as endogenously determined in the model; and (iv) disaggregated the measure of land use regulation to better assess the effect of each different component of land use legislation.

Some of the results confirmed the original hypothesis. An increase in minimum plot area, minimum front setback and minimum frontage decreases the density of occupation of land and in this study they show a positive effect on formal housing price, which is consistent with the hypothesis that more restrictive land use regulations increase housing price. But the results for maximum number of floors and floor-to-area ratio (FAR) are the opposite of what was expected, raising the possibility that the aggregation of single family houses and multifamily units might have distorted the results. 
The effect and spatial pattern of price determination on informality

The second and third hypotheses were the central part of this research because there is still disagreement about the substitution effect between formal and informal housing markets and because there is limited empirical research on the subject. This study suggests that indeed these two markets are interrelated, but in a more complex form than initially anticipated. Without incorporating spatial analysis, results of the effect of formal housing price on informality can be misleading.

The results of the present study suggest that in a given location, an increase in housing price decreases the quantity of informal housing in that location, which is contrary to what was expected. However, the study found that an increase in housing price in a particular location increases the quantity of informal housing in neighboring locations and this positive effect seems to increase as the locations move away from each other. The results indicate that the positive effect of price on informality in neighboring locations is greater than the negative effect on the same location, suggesting that, overall, the effect of price on informality is positive.

A possible explanation for these antagonistic results may be found in a recent theory developed by Brueckner and Selod (2008), who argue that formal residents and squatters compete for land, with squatters occupying land where the formal price of housing is less than the cost of eviction. In central locations, formal housing price has become too high for informal housing, increasing the possibility of eviction and forcing low and moderate income residents to find an informal housing solution in a 
more distant location. High prices in central locations, which are where high income households live, may also be acting as barrier to entry for low income households, keeping informal housing out of these areas. These results are consistent with the exclusionary pattern of occupation of Brazilian cities, where central locations are strictly regulated and occupied by high income households, while urban regulation is less stringently enforced in the periphery, inviting the informal market to provide housing for low and moderate income households.

\section{Implications for Urban Policy Practice in Brazil}

The review of the practice of urban policies in Brazil showed that in the late 1980s there was a shift in the formulation of urban policies in Brazil. The new Constitution of 1988 and the Federal Law 10,257 of 2001, known as the City Statute, provided instruments to make land use regulation more permissive in order to make housing more affordable to low-income families.

Now that municipalities are at the center of urban policy and legislation at the federal level encourages municipalities to review their land use regulation and make it less stringent, it is pertinent for practitioners to understand to what extent land use regulation can reduce the price of formal housing and how the price of formal housing can affect the growth of the informal housing sector.

This research shows that some land use regulations that allow more density of occupation can reduce the price of housing, namely minimum plot area, minimum 
front setback and minimum frontage. The research also shows that a decrease in formal housing price can decrease the quantity of informal housing in the city as a whole, although this can't be achieved without taking into consideration how this relationship changes in the territory. These findings can assist practitioners in better estimating the cost of land use regulation, informing citizens about the implications of land use regulation revisions, and better targeting urban development policies according to different spatial patterns of occupation.

This research also reveals the pervasive effect of creating exclusionary pockets in the city. Generally, more permissive land use regulations are allowed in predetermined areas targeted to the construction of affordable housing. These predetermined areas are generally located in the periphery, reinforcing the spatial pattern of segregation of the city. Instead, it might be advisable to consider policies that better integrate social groups in all areas of the city and demonstrate flexibility in land use requirements in all locations.

\section{Limitations of the Study}

Scale, Period and Sample Size

Focusing this research on a particular market, namely the metropolitan area of Curitiba, had the advantage of avoiding the aggregation bias that characterizes the studies that have used a national focus, and provided an opportunity to understand the spatial pattern of the variables of interest and their relationships. However, the scale

of this research also comes with its shortcomings. Curitiba is just one of several 
metropolitan areas in Brazil and caution should be used when generalizing the results from this study to the rest of the country, not to mention to other developing countries. The south of Brazil, and particularly Parana and Curitiba, being historically more equitable and having a stronger tradition of planning, had a distinct history of urban development compared to the rest of the country. Therefore research needs to be done in other metropolitan areas to corroborate the results obtained here.

Another important limitation of this study is with respect to the period of analysis. Ideally, I would have included two different years in the analysis to cover a larger period of time and help compare the results from one period to the other and track the changes that occurred between those periods. Unfortunately, for several variables there was no information available for an earlier period. This was the case of the variables that depended on the municipal cadastres for property tax purposes. These variables were comprised of: (a) the assessed value of residential properties, which was used as the formal housing price; (b) the floor space of residential properties; and (c) the property tax applied to residential properties. The regulatory variables were impossible to get for an earlier period. In several municipalities, older versions of the zoning map were destroyed after a new zoning map was approved and only at COMEC - the metropolitan entity - some of this history could be recovered. Now that several new zoning regulations were approved between 2000 and 2008, and with the new census information anticipated in 2010 , it will be possible to replicate this research and compare the results. 
The small sample size is yet another limitation of this study. It would have been ideal to have more than 108 units of analysis. For that, a more disaggregated unit of analysis would have been required. It might be possible to define smaller units of analysis, maybe using the census tract, or a smaller aggregation of census tract. The difficulty is integrating this information with the municipal cadastres, which are not generated at the census tract level. Other sources of information were tried unsuccessfully. SECOVI, the organization that represents real estate firms and collects data on houses for sale, had the same level of aggregation as the municipality of Curitiba. Caixa Economica Federal (CEF), the federal state-owned bank that issues mortgages to moderate income families and has a database of properties with geographic reference. Unfortunately I did not have access to this database.

\section{Measurement and Data}

Mentioned above was the difficulty in measuring housing price, urban regulation and housing informality in general, but particularly in Brazil. Housing price is something that is not directly observed. What is observed is housing expenditure and the price can be estimated by "decomposing" the price of the different attributes of housing using a hedonic function. To make matters worse, in Brazil it is very difficult to observe even housing expenditures, as this information is not readily available as in the United States. SECOVI has a monthly database that collects the price asked in sale ads since 1994. In addition to having a price that isn't reliable, the database doesn't cover all municipalities in the metropolitan area and it has other flaws. The municipal assessment of property values have problems of a different nature such as: 
an assessment at below market value; areas with outdated market values; outdated information about property characteristics; and difficulties in getting uniform information on the characteristics of the properties across all municipalities. Despite the problems of this data source, it was used because it was assumed that the problems affected all areas equally.

Land use regulation is another difficult variable to measure in general. Zoning categories have several land use requirements and exceptions to the rule. Deciding which one should be picked to measure the stringency of the regulatory environment is a challenge. In addition, a particular zone or neighborhood generally has more than one, if not several, zoning categories that apply to different areas inside the boundaries of the neighborhood such as: a park that has a protective zoning status, a school area that has institutional zoning, residential areas with several zoning categories, or commercial areas where residencies are allowed under special conditions. Deciding which zoning category dominates is a challenge. In this study, a methodology to arrive at a median density zoning was developed to help deal with these challenges.

The problem of measuring housing informality was also mentioned above. Large and rich municipalities generally have the best inventory of informal housing because it is generally used for municipal housing policies of slum upgrading or regularization of irregular land subdivision. The problem is that not all municipalities have the resources or the political will to carry such an inventory, and those that do, carry them 
with different methodologies and in different years. It is for that reason that most researchers use the census data when a study involves more than one municipality. There is general consensus that the census information on informal housing underestimates the size of the informal housing sector, but as was assumed with the price variable, it is assumed that the underestimation affects all areas equally so it shouldn't affect the results. 
Appendices 


\section{Appendix I - Summary of the Literature on Land Use Regulation and Housing Price in Developing Countries}

\begin{tabular}{|c|c|c|c|c|c|c|c|}
\hline Author(s) & Year & $\begin{array}{l}\text { Geography } \\
\text { Covered }\end{array}$ & Regulatory Measure & $\begin{array}{l}\text { Housing Price } \\
\text { Measure }\end{array}$ & $\begin{array}{l}\text { Other } \\
\text { Variables } \\
\end{array}$ & Method & Results \\
\hline $\begin{array}{l}\text { Hannah, } \\
\text { Kim and } \\
\text { Mills }\end{array}$ & 1993 & $\begin{array}{l}\text { South Korea } \\
\text { (country, city } \\
\text { and project } \\
\text { level) }\end{array}$ & $\begin{array}{l}\text { Government permission to land } \\
\text { conversion from rural to urban for } \\
\text { residential use. }\end{array}$ & $\begin{array}{l}\text { National housing } \\
\text { price index, } \\
\text { national land } \\
\text { price index and } \\
\text { construction } \\
\text { material price } \\
\text { index }\end{array}$ & & $\begin{array}{l}\text { Analysis of } \\
\text { housing price } \\
\text { and related } \\
\text { series; analysis } \\
\text { of time series of } \\
\text { land use } \\
\text { pattern; and } \\
\text { case studies of } \\
\text { five Seoul } \\
\text { development } \\
\text { projects }\end{array}$ & $\begin{array}{l}\text { National housing price rose more than } \\
\text { twice as fast as consumer price index } \\
\text { between } 1974 \text { and } 1980 \text { and land } \\
\text { price is pointed as the main cause of } \\
\text { it. The share of land for residential } \\
\text { use fell from } 11.5 \% \text { to } 8.9 \% \text { and } \\
\text { residential land per resident decrease } \\
20 \% \text { between } 1973 \text { and } 1988 \text { due to } \\
\text { under- allocation residential land, } \\
\text { according to authors. Land with } \\
\text { infrastructure for residential use was } \\
1.7 \text { to } 6.5 \text { times more expensive than } \\
\text { raw rural land and large difference is } \\
\text { result of disequilibrium due to } \\
\text { government undersupply of } \\
\text { conversion permission, according to } \\
\text { authors. }\end{array}$ \\
\hline $\begin{array}{l}\text { Green, } \\
\text { Malpezzi } \\
\text { and } \\
\text { Vandell }\end{array}$ & 1994 & South Korea & $\begin{array}{l}\text { A combination of governmental } \\
\text { regulatory policies on financing, tax and } \\
\text { land use. }\end{array}$ & $\begin{array}{l}\text { Several price } \\
\text { measures used in } \\
\text { the literature } \\
\text { reviewed }\end{array}$ & & $\begin{array}{l}\text { Literature } \\
\text { review }\end{array}$ & $\begin{array}{l}\text { On the demand side, Korea shows } \\
\text { rising aggregate demand for housing } \\
\text { due to growth in urban population, } \\
\text { household and income. Similarly to } \\
\text { US, demand for housing seems to be } \\
\text { responsive to income and price, with } \\
\text { elasticities below } 1 \text {. On the supply } \\
\text { side, studies found housing to be price } \\
\text { inelastic, explaining price rise with } \\
\text { rise in demand. In addition to } \\
\text { geographical barriers, a main factor } \\
\text { explaining inelastic supply of housing } \\
\text { is urban regulation and policies } \\
\text { affecting land development } \\
\text { (limitation on land conversion, green } \\
\text { belts, tax on intensive land use) and } \\
\text { housing finance (credit constraints to } \\
\text { housing finance) }\end{array}$ \\
\hline
\end{tabular}




\begin{tabular}{|c|c|c|c|c|c|c|c|}
\hline Bertaud & 1996 & $\begin{array}{l}\text { Ahmadabad, } \\
\text { India }\end{array}$ & Floor Area Ratio (FAR) & $\begin{array}{l}\text { Land price } \\
\text { gradients }\end{array}$ & $\begin{array}{l}\text { Density } \\
\text { gradients }\end{array}$ & $\begin{array}{l}\text { Comparison of } \\
\text { density and } \\
\text { land price } \\
\text { profile in } \\
\text { Ahmadabad } \\
\text { and in cities } \\
\text { where land use } \\
\text { density is less } \\
\text { restraint. }\end{array}$ & $\begin{array}{l}\text { Author concludes that FAR restriction } \\
\text { distorts land prices, showing that in } \\
\text { most markets where land market } \\
\text { operates well, there is correlation } \\
\text { between density and price gradients } \\
\text { while in Ahmadabad there is } \\
\text { discrepancy. }\end{array}$ \\
\hline Brueckner & 1996 & $\begin{array}{l}\text { South } \\
\text { African cities }\end{array}$ & Apartheid Land Use Restriction & & & $\begin{array}{l}\text { Theoretical } \\
\text { model based on } \\
\text { urban model } \\
\text { developed by } \\
\text { Alonso (1964) }\end{array}$ & $\begin{array}{l}\text { Removal of apartheid land use } \\
\text { restriction, blacks compete for land } \\
\text { close to employment center, } \\
\text { displacing whites. Blacks have } \\
\text { welfare gain because of decrease in } \\
\text { commuting cost, while whites suffer } \\
\text { welfare loss because of longer } \\
\text { commutes. Landowners benefit } \\
\text { because of increase in total land rent } \\
\text { due to greater competition, this gain is } \\
\text { greater than whites' losses, so there is } \\
\text { aggregate welfare gain from removing } \\
\text { apartheid land use restriction. }\end{array}$ \\
\hline $\begin{array}{l}\text { Mayo and } \\
\text { Sheppard }\end{array}$ & 1996 & $\begin{array}{l}\text { Malaysia, } \\
\text { Thailand and } \\
\text { South Korea } \\
\text { (country- } \\
\text { level) }\end{array}$ & $\begin{array}{l}\text { Level of regulatory restrictiveness, } \\
\text { comparing three countries: South Korea } \\
\text { being the most restrictive; Thailand, the } \\
\text { least; and Malaysia the intermediate. }\end{array}$ & $\begin{array}{l}\text { National housing } \\
\text { price indexes for } \\
\text { each country }\end{array}$ & $\begin{array}{l}\text { Income, factor } \\
\text { prices for } \\
\text { housing } \\
\text { production, and } \\
\text { the price of } \\
\text { other goods }\end{array}$ & $\begin{array}{l}\text { OLS and } \\
\text { autoregressive } \\
\text { least squares to } \\
\text { find price } \\
\text { elasticity of } \\
\text { supply for } \\
\text { housing. Also } \\
\text { uses a recursive } \\
\text { model to } \\
\text { estimate the } \\
\text { change in price } \\
\text { over time. }\end{array}$ & $\begin{array}{l}\text { Results show that Malaysia and Korea } \\
\text { had low elasticities of supply, while } \\
\text { Thailand had high elasticity. The } \\
\text { recursive model showed that although } \\
\text { Korea and Thailand were relatively } \\
\text { stable over time, Malaysia had high } \\
\text { elasticity in the years immediately } \\
\text { after the adoption of more restrictive } \\
\text { planning system, but over time supply } \\
\text { became less elastic. }\end{array}$ \\
\hline
\end{tabular}




\begin{tabular}{|c|c|c|c|c|c|c|c|}
\hline $\begin{array}{l}\text { Malpezzi } \\
\text { and Mayo }\end{array}$ & 1997 & $\begin{array}{l}\text { Malaysia, } \\
\text { Thailand, } \\
\text { and South } \\
\text { Korea } \\
\text { (country- } \\
\text { level) }\end{array}$ & $\begin{array}{l}\text { Estimates cost of: (i) percentage of } \\
\text { saleable area (area that is sold after } \\
\text { subtracting requirements for road size, } \\
\text { setback, and community facilities); (ii) } \\
\text { approval time; (iii) building code } \\
\text { requirements and regulation encouraging } \\
\text { sales to special ethnic groups. Malaysia } \\
\text { is compared with Thailand (less } \\
\text { restrictive) and South Korea (similar } \\
\text { restrictiveness) }\end{array}$ & $\begin{array}{l}\text { National housing } \\
\text { price indexes }\end{array}$ & $\begin{array}{l}\text { Similar to } \\
\text { Mayo and } \\
\text { Sheppard } \\
(1996)\end{array}$ & $\begin{array}{l}\text { Cost-benefit } \\
\text { model using } \\
\text { present value } \\
\text { analysis as in } \\
\text { Bertaud and } \\
\text { Malpezzi } \\
\text { (2001) and } \\
\text { model similar } \\
\text { to Mayo and } \\
\text { Sheppard } \\
\text { (1996) for the } \\
\text { three country } \\
\text { comparison }\end{array}$ & $\begin{array}{l}\text { The cost-benefit analysis indicates } \\
\text { that interventions add about } \$ 4,000 \\
\text { (Malaysian) to developer's cost. The } \\
\text { cross-country comparison indicates } \\
\text { that Malaysia and Korea have } \\
\text { inelastic housing supply curves and } \\
\text { Thailand has an elastic curve, similar } \\
\text { to the United States. }\end{array}$ \\
\hline
\end{tabular}

\begin{tabular}{|c|c|c|c|c|c|c|c|}
\hline Somekh & 1999 & $\begin{array}{l}\text { Diadema, SP, } \\
\text { Brazil }\end{array}$ & $\begin{array}{l}\text { Special Area of Social Interest (AEIS) - } \\
\text { zoning areas designated to the } \\
\text { construction of social housing with less } \\
\text { restraining regulatory requirements. }\end{array}$ & Not shown & & Not clear & $\begin{array}{l}\text { Author concludes that AEIS led to a } \\
\text { decrease in the price of land located } \\
\text { in areas designated as such, because } \\
\text { of increase supply of land allocated to } \\
\text { this use, but author doesn't provide } \\
\text { any evidence of it. }\end{array}$ \\
\hline Angel & 2000 & $\begin{array}{l}\text { Global cross- } \\
\text { country } \\
\text { analysis of } \\
38 \text { or } 45 \\
\text { countries } \\
\text { depending on } \\
\text { the model } \\
\text { used }\end{array}$ & $\begin{array}{l}\text { Regulatory Regime Index, a composite } \\
\text { measure of three indicators: permit } \\
\text { delays, minimum lot size, and minimum } \\
\text { floor area. The last two indicators were } \\
\text { normalized by dividing them by the } \\
\text { median house size. } \\
\text { The regulatory index and four other } \\
\text { indexes (property rights regime index, } \\
\text { housing finance regime index, housing } \\
\text { subsidy index, and residential } \\
\text { infrastructure index) were equally } \\
\text { weighted into a composite index, the } \\
\text { Enabling Index. }\end{array}$ & $\begin{array}{l}\text { Housing price } \\
\text { index, housing } \\
\text { rent index (both } \\
\text { normalized by a } \\
\text { construction } \\
\text { quality index), } \\
\text { and weighted } \\
\text { housing price } \\
\text { index (a } \\
\text { combination of } \\
\text { housing price } \\
\text { and rent indexes) }\end{array}$ & $\begin{array}{l}\text { Log of } \\
\text { household } \\
\text { income, city } \\
\text { population } \\
\text { growth rate, } \\
\text { housing credit } \\
\text { portfolio, } \\
\text { construction } \\
\text { cost-to-income } \\
\text { ratio, land cost- } \\
\text { to-income ratio }\end{array}$ & OLS & $\begin{array}{l}\text { A more enabling housing policy } \\
\text { environment significantly lowers } \\
\text { housing price index, housing rent } \\
\text { index in countries with little or no } \\
\text { rent control and weighted housing } \\
\text { price index in countries with little or } \\
\text { no rent control. }\end{array}$ \\
\hline
\end{tabular}




\begin{tabular}{|c|c|c|c|c|c|}
\hline $\begin{array}{l}\text { Bertaud } \\
\text { and } \\
\text { Malpezzi }\end{array}$ & 2001 & $\begin{array}{l}\text { Malaysia } \\
\text { (project- } \\
\text { level) }\end{array}$ & $\begin{array}{l}\text { Authors identify what they believe are } \\
\text { the two most important indicators of } \\
\text { urban regulation: floor area ratio (FAR - } \\
\text { building's total floor area divided by } \\
\text { area of land plot) and percentage of } \\
\text { saleable area (the area that can be sold } \\
\text { after taking away areas required for } \\
\text { public use such as streets, public schools } \\
\text { and parks). }\end{array}$ & $\begin{array}{l}\text { Cost-benefit } \\
\text { model of land } \\
\text { use and related } \\
\text { regulations, } \\
\text { where benefits } \\
\text { are roughly } \\
\text { estimated } \\
\text { comparing } \\
\text { current } \\
\text { regulation and } \\
\text { practice to a } \\
\text { baseline based } \\
\text { on market } \\
\text { comparison and } \\
\text { "international } \\
\text { practice". }\end{array}$ & $\begin{array}{l}\text { Under current regulation for low } \\
\text { income developments, only } 44 \% \text { of } \\
\text { the land is saleable and FAR is only } \\
0.23 \text {. As a consequence, developers } \\
\text { have a profitability that is } 15 \% \text { below } \\
\text { the baseline of a middle income } \\
\text { development. } \\
\text { With suggested reduction in road } \\
\text { width, elimination of black alleys and } \\
\text { reduction of corner setback } \\
\text { requirements saleable area rises to } \\
55 \% \text { and FAR rises to } 0.41 \text {. These } \\
\text { changes make profitability rise } 17 \% \\
\text { in comparison to the baseline of a } \\
\text { middle income development. }\end{array}$ \\
\hline $\begin{array}{l}\text { Bertaud, } \\
\text { Buckley } \\
\text { and } \\
\text { Owens }\end{array}$ & 2003 & $\begin{array}{l}\text { Mumbai, } \\
\text { India }\end{array}$ & Floor area ratio (FAR) & $\begin{array}{l}\text { Use the same } \\
\text { theoretical and } \\
\text { simulation } \\
\text { model used in } \\
\text { Bertaud and } \\
\text { Brueckner } \\
(2004)\end{array}$ & $\begin{array}{l}\text { Simulation analysis shows that FAR } \\
\text { increases the edge of the city by } 4 \mathrm{~km} \\
\text { and, as a result, increase commuting } \\
\text { cost by } 14 \% \text { of per capita income. } \\
\text { This cost is regressive: the cost for the } \\
\text { first income decile is } 10 \% \text { in } \\
\text { Bangalore and } 22 \% \text { in Mumbai }\end{array}$ \\
\hline $\begin{array}{l}\text { Bertaud } \\
\text { and } \\
\text { Brueckner }\end{array}$ & 2004 & $\begin{array}{l}\text { Bangalore, } \\
\text { India }\end{array}$ & Floor area ratio (FAR) & $\begin{array}{l}\text { Theoretical } \\
\text { approach using } \\
\text { standard } \\
\text { monocentric- } \\
\text { city model to } \\
\text { show how FAR } \\
\text { restrictions } \\
\text { affect land use; } \\
\text { and simulation } \\
\text { analysis to } \\
\text { predict changes } \\
\text { if FAR } \\
\text { restriction was } \\
\text { removed. }\end{array}$ & $\begin{array}{l}\text { Theoretical part shows that FAR } \\
\text { limits population density in the center } \\
\text { and causes the city to sprawl, } \\
\text { resulting in an increase in commuting } \\
\text { cost. Simulation analysis shows that } \\
\text { removing FAR restriction would } \\
\text { increase population density near the } \\
\text { center of the city, reduce the edge of } \\
\text { the city by } 2 \mathrm{~km} \text { and, as a result, } \\
\text { reduce commuting cost for residents } \\
\text { living at the edge. The commuting- } \\
\text { cost saving is estimated to range from } \\
3.3 \text { to } 5.0 \% \text { of per capita income and } \\
\text { between } 3.0 \text { and } 4.5 \% \text { of household } \\
\text { consumption. }\end{array}$ \\
\hline
\end{tabular}




\section{Bibliography}

Abramo, P. 2003. A Teoria Economica da Favela: Quatro Notas sobre a Localizacao Residencial dos Pobres e o Mercado Imobiliario Informal. In P. Abramo, ed. A Cidade de Informalidade: o Desafio da Cidades Latino-Americanas. Rio de Janeiro: Sete Letras.

Alves, A.C. 2006. O Processo de Criacao de Municipios no Parana: as Instituicoes e a relacao entre executivo e legislativo pos 1988. Revista Paranaense de Desenvolvimento 111: 47-71.

Angel, S., S.C. Sheppard and D.L. Civco. 2005. The Dynamics of Global Urban Expansion. Washington, DC: The World Bank.

Angel, S. 2000. Housing Policy Matters: a Global Analysis. Oxford University Press: New York.

Anselin, L., I. Syabri, and Y. Kho. 2006. GeoDa: An Introduction to Spatial Data Analysis. Geographical Analysis 38(1): 5-22.

Avila, P.C. 2007. Implications of Federal Law no 6,766/1979 and Local Laws on Land Subdivision on the Increase in Housing Informality in Brazil. Draft Paper. Cambridge, MA: Lincoln Institute of Land Policy.

Azevedo, S. and L.A.G. Andrade. 1982. Habitacao e Poder. Da Fundacao da Casa Popular ao Banco Nacional de Habitacao. Rio de Janeiro: Zahar.

Baross, P. and J.V.D. Linden, eds. 1990. The Transformation of Land Supply Systems in Third World Cities. Aldershot: Avebury.

Bertaud, A. 1996. Ahmadabad: Land Use Issues and Recommendations. World Bank. 
Bertaud. A. and J.K. Brueckner. 2004. Analyzing Building Heights Restrictions: Predicted Impacts, Welfare Costs and a Case Study of Bangalore, India. Policy Research Paper Working Paper 3290. Washington, DC: World Bank.

Bertaud, A., R. Buckley, and K. Owens. 2003. Is Indian Urban Policy Impoverishing? World Bank Urban Research Symposium. December 15-17. Washington, DC: World Bank.

Bertaud, A. and S. Malpezzi. 2001. Measuring the Costs and Benefits of Urban Land Use Regulation: a Simple Model with an Application to Malaysia. Journal of Urban Economics 10: 393-418.

Biderman, C. 2008. Informality in Brazil: Does Urban Land Use and Building Regulation Matter? Working Paper WP08CB1. Cambridge, MA: Lincoln Institute of Land Policy.

Brueckner, J.K. 1996. Welfare Gains from Removing Land Use Distortions. Journal of Regional Science 36 (1): 91-109.

Brueckner, J. K. and H. Selod. 2008. A Theory of Urban Squatting and Land-Tenure Formalization in Developing Countries. Working Paper Series 2328. Munich: Center for Economic Studies and Ifo Institute for Economic Research.

Buckley, R.M. and J. Kalarickal. 2005. Housing Policy in Developing Countries: Conjectures and Refutations. The World Bank Research Observer 20(2): 233257.

Cano, W. 1989. Urbanizacao: sua Crise e Revisao de seu Planejamento. Revista de Economia Politica 9(1): 62-82. 
Coordenação da Região Metropolitana de Curitiba (COMEC). 2006. Plano de Desenvolvimento Integrado da Região Metropolitana de Curitiba: propostas de ordenamento e novo arranjo institucional. Curitiba: COMEC.

Cymbalista, R. 2006. A Trajetoria Recente do Planejamento Territorial no Brasil: apostas e pontos a observer. Revista Paranaense de Desenvolvimento 111: 2945.

De Soto, H. 2000. The Mystery of Capital: Why Capitalism Triumphs in the West and Fails Everywhere Else. New York: Basic Book.

De Souza, F.A.M. 2002. De-constructing Urban Space in Informal Settlements: the case of Recife, Brazil. Paper presented to the Annual Conference of the Urban Issues Program Constructing Urban Space Teresa Losano-Long Texas at Austin. April 6, 2002.

Dedecca, C.S. 2005. Notas sobre a Evolucao do Mercado de Trabalho no Brasil. Revista de Economia Politica 25(1): 94-111.

Dowall, D.E. 1992. Benefits of Minimal Land-Use Regulations in Developing Countries. CATO Journal 12(2).

Drakakis-Smith, D., ed. 2000. Economic Growth and Urbanization in Developing Areas. London: Routledge.

Feler, L. and J. V. Henderson. 2008. Exclusionary Policies in Urban Development: How Under-Servicing of Migrant Households Affects the Growth and Composition of Brazilian Cities. NBER Working Paper 14136. Cambridge: National Bureau of Economic Research. 
Fernandes, E. 1997. Access to Urban Land and Housing in Brazil: Three Degrees of Illegality. Working Paper WP97EF1. Cambridge, MA: Lincoln Institute of Land Policy.

Ferreira, F.H.G., P.G. Leite, and J.A.Litchfield. 2006. The Rise and Fall of Brazilian Inequality: 1981-2004. Policy Research Working Paper 3867. Washington, DC: World Bank.

Fischel, W. A. 1990. Do Growth Control Matter? A Review of Empirical Evidence on the Effectiveness and Efficiency of Local Government Land Use Regulation. Lincoln Institute of Land Policy Working Paper. Cambridge, MA: Lincoln Institute of Land Policy.

Folha de Sao Paulo. 2000. Metade de Sao Paulo mora em habitação irregular. 04/06/2000.

Gilbert, A. 1990. The Costs and Benefits of Illegality and Irregularity in the Supply of Land. In The Transformation of Land Supply Systems in Third World Cities. P. Baross and J.V.D. Linden, eds. Aldershot: Avebury.

Green, R.K. 1999. Land Use Regulation and the Price of Housing in a Suburban Wisconsin County. Journal of Housing Economics 8: 144-159.

Green, R. K., S. Malpezzi, and K. Vandell. 1994. Urban Regulations and the Price of Land and Housing in Korea. Journal of Housing Economics 3: 330-356.

Hannah, L, K. H. Kim, and E. Mills. 1993. Land Use Controls and Housing Prices in Korea. Urban Studies 30(1): 147-156. 
Hereda, J., S.S.K. Nagai, J. Klink, and N. Baltrusis. 1997. O Impacto das AEIS no Mercado Imobiliário de Diadema. In R. Rolnik and R. Cymbalista, eds. Instrumentos Urbanísticos contra a Exclusão Social. São Paulo: POLIS.

Holston, J. 1991. Auto construction in Working-Class Brazil. Cultural Anthropology 6(4): 447-465.

Instituto Brasileiro de Geografia e Estatistica (IBGE). 2003. Cai a participação do Sudeste no PIB e sobe a dos estados ligados à agroindústria. Contas Regionais do Brasil 2003. Retrieved in 11/20/2008 from http://www.ibge.com.br/home/presidencia/noticias/noticia_visualiza.php?id_noticia=470\&id_pagina=1

Instituto Paranaense de Desenvolvimento Economico e Social (IPARDES). 2005. Indicadores Intra-metropolitanos 2000: diferencas socioespaciais na regiao metropolitana de Curitiba. Curitiba: IPARDES.

Kowarick, L. 1980. A Espoliacao Urbana. Rio de Janeiro: Paz e Terra

Lago, L. and L.C.Q Ribeiro. 1996. A Casa Propria em Tempo de Crise. In A Crise da Moradia nas Grandes Cidades: da questao da habitacao a reforma urbana. L.C.Q. Ribeiro and S Azevedo, eds. Rio de Janeiro: UFRJ.

Lall, S.V., H.G. Wang, and D.D. Mata. 2006. Do Urban Land Regulations Influence Slum Formation? Evidence from Brazilian Cities. Paper prepared for the World Bank for the program grant "Dynamics of Slum Formation and Strategies to Improve Lives of Slums Dwellers".

Linden, E. 1996. The Exploding Cities of the Developing World. Foreign Affairs 75(1): 52-65. 
Lomar, P. V. 2004. Legislacao do Uso do Solo, Propiedade Urbana e Registro de Imoveis no Brasil. In Enabling Strategy for Moving Upgrading to Scale in Brazil. M.V.Serra and D. Motta, eds. Washington, DC: Cities Alliance.

Malpezzi, S. 1996. Housing Prices, Externalities and Regulation in U.S. Metropolitan Areas. Journal of Housing Research 7(2): 209-241.

Malpezzi, S. 1999. The Regulation of Urban Development: Lessons from International Experience. Draft. Center for Urban Land Economics Research. University of Wisconsin-Madison.

Malpezzi, S., G.H. Chun \& R. Green. 1998. New Place-to-Place Price Indexes for US Metropolitan Areas and their Determinants. Real Estate Economics 26(2): 235-274.

Malpezzi, S. and S. K. Mayo. 1997. Getting Housing Incentives Right: A Case Study of the Effects of Regulation, Taxes and Subsidies on Housing Supply in Malaysia. Land Economics 73 (3): 372-91.

Maricato, E. 1996. Metropole na Periferia do Capitalismo: Ilegalidade, Desigualdade e Violencia. Sao Paulo: Hucitec.

Mayo, S. K. and S. Sheppard. 1996. Housing Supply Under Rapid Economic Growth and Varying Regulatory Stringency: and International Comparison. Journal of Housing Economics 5 (3): 274-289.

Melo, M.A.B.C. 1990. Estruturacao Intra-Urbana, Regimes de Acumulacao e Sistemas Financeiros da Habitacao: Brasil em Perspectiva Comparada. Espaco e Debates (10)31: 37-51. 
Nojima, D., R. Moura, and S.T. Silva. 2004. Dinamica Recente da Economia e Transformacoes na Configuracao Espacial da Regiao Metropolitana de Curitiba. Curitiba: IPARDES.

Olsen, E. 1987. The Demand and Supply of Housing Service: a Critical Survey of the Empirical Literature. In Handbook of Regional and Urban Economics Vol. II. E.S. Mills, ed. New York: Elsevier.

Pamuk, A 2000. Informal institutional arrangements in credit, land markets and infrastructure delivery in Trinidad. International Journal of Urban and Regional Research 24 (2).

Prefeitura do Rio de Janeiro and Inter American Development Bank. 2003. FavelaBairro: Ten Years Integrating the City. Rio de Janeiro: Prefeitura do Rio de Janeiro.

Quigley, J.M. \& L.A. Rosenthal. 2005. The Effects of Land Use Regulation on the Price of Housing: What do we know? What can we learn? Cityscape 8: 69137.

Rezende, F. 1997. Financiamento do Desenvolvimento Urbano. Revista de Economia Politica 17(4): 99-120.

Rolnik, R. 1998. Impacto da Aplicacao de Novos Instrumentos Urbanisticos em Cidades do Estado de Sao Paulo. Lincoln Institute Research Report. Cambridge, MA: Lincoln Institute of Land Policy.

Roy, A. 2005. Urban Informality: Towards an Epistemology of Planning. Journal of the American Planning Association 71(2): 147-158. 
Roy, A. and N. Alsayyad, eds. 2004. Urban Informality: Transnational Perspectives from the Middle East, Latin America, and South Asia. Lanham, MD: Lexington Books.

Sadoulet, E. 1985. Crescimento Desigualitario emu ma Economia Subdesenvolvida: o Caso do Brasil. Revista de Economia Politica 5(2): 67-97.

Schill, M. H. 2005 Regulations and Housing Development: What We Know. Cityscape 8: 5-19.

Serra, M.V, D.E. Dowall, and D.M. Motta. 2005. Urban Land Markets and Urban Land Development: an Examination of Three Brazilian Cities: Brasilia, Curitiba, and Recife. In Enabling Strategy for Moving Upgrading to Scale in Brazil, M.V.Serra and D. Motta, eds. Washington, DC: World Bank/Cities Alliance.

Serra, M.V., R. Pontual, and M.C. Cintra. 2005. Segundo Volume: analise espacial e ambiental dos assentamentos habitacionais informais. In Enabling Strategy for Moving Upgrading to Scale in Brazil, M.V.Serra and D. Motta, eds. Washington, DC: World Bank/Cities Alliance.

Smolka, M. O. 2003. Informality, Urban Poverty and Land Market Prices. Land Lines 15(1).

Somekh, N. 1999. AEIS de Diadema - Impacto nos Preços Fundiários. Lincoln Institute Research Report. Cambridge, MA: Lincoln Institute of Land Policy.

Souza, M.T. 1999. O Programa de Cooperativas Habitacionais do BNH: Cooperativismo Inventado. Dissertacao de Mestrado. Sao Paulo: Faculdade de Arquitetura e Urbanismo da Universidade de Sao Paulo. 
Suzigan, W. 1988. Estado e Industrializacao no Brasil. Revista de Economia Politica 8(4): 5-16.

Suzigan, W. 1984. Notas sobre Desenvolvimento Industrial e Politica Economica no Brasil na Decada de 30. Revista de Economia Politica 4(1): 132-143.

Taschner, S.P. 2003. O Brasil e Suas Favelas. In A Cidade da Informalidade: o Desafio das Cidades Latino-Americanas. P. Abramo, ed. Rio de Janeiro: Sette Letras.

Tavares, M. da C. And P.R. Souza. 1981. Emprego e Salarios na Industria: o Caso Brasileiro. Revista de Economia Politica 1(1): 3-29.

United Nations. 2004. World Urbanization Prospects: The 2003 Revision. New York: United Nations.

Valladares, L. And A. Figueiredo. 1983. Housing in Brazil: an Introduction to Recent Literature. Bulletin of Latin American Research 2(2): 69-91. 